CONTRERAS, Lautaro. "La posición de garante del fabricante en el Derecho penal alemán".

Polít. crim. Vol. 12, № 23 (Julio 2017), Art. 1, pp. 1-55.

[http://www.politicacriminal.cl/Vol_12/n_23/Vol12N23A1.pdf]

\title{
La posición de garante del fabricante en el Derecho penal alemán
}

\section{The manufacturer's position of guarantor in German Penal law}

\author{
Lautaro Contreras Chaimovich* \\ Legum magister y doctor por la Albert-Ludwigs-Universität (Alemania). \\ Profesor asociado del Departamento de Ciencias Penales, Universidad de Chile. \\ lcontreras@derecho.uchile.cl
}

\section{Resumen}

El presente artículo analiza los planteamientos desarrollados por la doctrina alemana para fundamentar una posición de garante del fabricante. Estas propuestas dogmáticas surgieron como reacción al fallo dictado por el Tribunal Supremo Federal en el caso del espray para cuero. En la sentencia, se justificó una responsabilidad por omisión impropia del fabricante sobre la base de una conducta previa contraria a deber. Luego de exponer y valorar el planteamiento de la sentencia en materia de injerencia, el artículo aborda de manera crítica las soluciones que ha desarrollado la dogmática para justificar una posición de garante del fabricante. Al final, se plantea una propuesta alternativa de fundamentación de esta posición, que destaca el especial provecho que obtiene el fabricante de los riesgos de desarrollo y de las expectativas de los consumidores.

Palabras clave: Responsabilidad penal por el producto, posición de garante, injerencia, asunción de una función de protección, deberes de aseguramiento del tráfico, riesgos de desarrollo, Derecho Penal de la Empresa.

\section{Zusammenfassung}

Der Aufsatz analysiert der von den deutschen Lehre entwickelten Stellungnahmen zur Begrüdung einer Garantenstellung des Herstellers. Solche Stellungnahmen stellten eine Reaktion auf die Lederspray-Entscheidung des BGH dar. In dieser Entscheidung wurde eine Verantwortlichkeit wegen unechten Unterlassungsdelikt durch ein vorangegangenes pflichtwidrigen Tun begründet. Nachdem die auf die Ingerenz stützende Argumentation des BGH analysiert wird, werden die von der Dogmatik entwickelten Lösungen zur Begründung einer Garantenstellung des Herstellers dargelegt und kritisiert. Der Verfasser vertritt der Auffassung, dass die Garantestellung des Herstellers auf die Vorteilsziehung der Entwicklungsrisiken und der Erwartungen der Konsumenten begründen werden kann.

Stichworte: strafrechtliche Produktveratwortung, Garantenstellung, Ingerenz, Übernahme einer Schutzfunktion, Verkehrssicherungspflichten, Entwicklungsrisiken, Unternehmensstrafrecht.

\footnotetext{
* Agradezco al profesor Dr. Héctor Hernández Basualto por sus valiosas observaciones a la versión preliminar del presente trabajo.
} 
CONTRERAS, Lautaro. "La posición de garante del fabricante en el Derecho penal alemán”.

\section{Introducción}

Cualquier sistema económico que se base en los principio de división del trabajo y de intercambio de mercancías genera riesgos para los bienes jurídicos de los consumidores ${ }^{1}$; la fabricación y comercialización de productos puede dar origen a cursos causales lesivos para la vida o salud de sus destinatarios finales. El potencial de peligro que envuelve la actividad que despliegan fabricantes y distribuidores es significativamente elevado. Por una parte, existen riesgos del producto -los denominados riesgos de desarrollo- que en ocasiones no pueden ser reconocidos al momento de su comercialización, ni siquiera cumpliendo cabalmente los deberes de cuidado que rigen la respectiva actividad ${ }^{2}$. Por otra, un solo acto negligente que tenga lugar en el seno de la empresa fabricante puede afectar a cientos o incluso miles de consumidores, debido a los sofisticados sistemas actuales de producción en serie y distribución masiva.

Para hacer frente a los riesgos del producto y garantizar altos estándares de seguridad en los bienes de consumo, Chile, como otros países, ha establecido un sistema de normas de Derecho administrativo que fija condiciones de fabricación ${ }^{3}$, impone ciertos estándares en el diseño ${ }^{4}$, faculta a servicios públicos para realizar visitas inspectivas a las empresas fabricantes ${ }^{5}$ o supedita la introducción en el mercado de ciertos bienes al otorgamiento de permisos $^{6}$. Las medidas de prevención de riesgos del producto, previstas en el Derecho administrativo, son complementadas a través de los sistemas de responsabilidad civil extracontractual contemplados en el art. 2.314 del Código Civil y en el inciso primero del art. 23 de la Ley N. 19.496 sobre protección de los derechos de los consumidores, que persiguen, primordialmente, la compensación de los daños ocasionados por el fabricante ${ }^{7}$. Naturalmente, el Derecho penal también interviene frente a la lesión o puesta en peligro de

\footnotetext{
${ }^{1}$ Cfr. WEI $\beta$, Holger, Die rechtliche Gewährleistung der Produktsicherheit, Baden-Baden: Nomos, 2008, p. 35 .

${ }^{2}$ Sobre los riesgos de desarrollo véase BODEWIG, Theo, Der Rückruf fehlerhafter Produkte Eine Untersuchung der Rückrufpflichten und Rückrufansprüche nach dem Recht Deutschlands, der Europäischen Union und der USA, Tübingen: Mohr Siebeck, 1999, pp. 51, 59 y 107. En el Derecho chileno véase CORRAL, Hernán, Responsabilidad por productos defectuosos Análisis y propuestas para el Derecho Civil y de Consumo en Chile, Santiago de Chile: Legal Publishing, 2011, pp. 132, 238 y ss. La Ley No 19.496 sobre protección de los derechos de los consumidores (cfr. su artículo 47 inciso segundo) excluye la responsabilidad (civil) por tales riesgos, puesto que no es razonable que el fabricante esté obligado a impedir aquellos cursos peligrosos para los bienes jurídicos de los consumidores que no puedan reconocerse desde una perspectiva ex ante. Se trata de riesgos tolerados por el orden jurídico pre-penal y, en consecuencia, no pueden fundamentar una responsabilidad criminal, en atención al carácter siempre accesorio del Derecho Penal.

${ }^{3}$ Véase, a título ejemplar, el art. 18 del Reglamento Sanitario de los Alimentos.

${ }^{4}$ Véase, por ejemplo, el inciso segundo del art. $5^{\circ}$ del Reglamento sobre Seguridad de los Juguetes.

${ }^{5}$ Véase, por ejemplo, el art. 103 del Código Sanitario.

${ }^{6}$ Cfr. por ejemplo el art. 99 del Código Sanitario.

${ }^{7}$ Sobre las funciones de compensación de daños y preventivas que cumplen las normas de sanción civiles en materia de responsabilidad por el producto puede verse COLUSSI, Marc, Produzentenkriminalität und strafrechtliche Verantwortung, Frankfurt am Main: Peter Lang, 2003, p. 48; GROßE VORHOLT, André, Behördliche Stellungnahmen in der strafrechtlichen Produkthaftung Zur Konkretisierung von Sorgfaltspflichten bei Risikoentscheidungen, Baden-Baden: Nomos, 1997, p. 161; HOLTERMANN, Christian, Neue Lösungsansätze zur strafrechtlichen Produkthaftung Eine Untersuchung unter Heranziehung des Tatbestandes der gemeingefährlichen Vergiftung \$ 314 Abs. 1 Nr. 2 StGB, Baden-Baden: Nomos, 2007, p. 47.
} 
Polít. crim. Vol. 12, № 23 (Julio 2017), Art. 1, pp. 1-55.

[http://www.politicacriminal.cl/Vol_12/n_23/Vol12N23A1.pdf]

los bienes jurídicos de los consumidores, provocada por la fabricación y comercialización de productos defectuosos. En el caso chileno "ADN" se hizo efectiva precisamente la responsabilidad criminal de un directivo y de algunos mandos medios de una empresa perteneciente al área de la salud, quienes distribuyeron un alimento enteral a lo largo del país con infracción de deber ${ }^{8}$.

A diferencia de lo ocurrido en Chile, donde el debate se encuentra en sus albores ${ }^{9}$, en Alemania se ha suscitado una intensa discusión dogmática acerca de distintos aspectos de la responsabilidad penal por el producto, a la que sirvieron de acicate los conocidos casos "Contergan" "10, del "espray para cuero" $" 11$ y del "producto protector de madera"12. Entre los temas tratados por la doctrina alemana se encuentran los siguientes: el carácter activo u omisivo de la conducta del fabricante ${ }^{13}$; la relación causal entre la introducción en el mercado de un producto y las muertes o lesiones de los consumidores ${ }^{14}$; los criterios para

\footnotetext{
${ }^{8}$ Véase la sentencia de 24.08.2012 TOP San Bernardo, RIT 38-2011, RUC 0800102576-8.

${ }^{9}$ Hay que destacar en la materia los trabajos de HERNÁNDEZ, Héctor, "El problema de la "causalidad general" en el derecho penal chileno (con ocasión del art. 232 del Anteproyecto de Nuevo Código Penal)", Polít. crim. $\mathrm{n}^{\circ} 1,2006$, A7, pp. 1-33, en: http://www.politicacriminal.cl/n_01/pdf_01/a 7.pdf [visitado el 15/09/16]; VAN WEEZEL, Alex, “Autoría y responsabilidad por el producto: ¿participación en decisiones de órganos colegiados como intervención delictiva?”, en: VAN WEEZEL, Alex, Pena y Sentido Estudios de Derecho Penal, Lima: Editorial Ara, 2008, pp. 371-396; CONTRERAS, Lautaro, "La responsabilidad penal del fabricante por la infracción de sus deberes de vigilancia, advertencia y retirada", Polít. crim. n o 19 (Julio 2015), Art. 9, pp. 266-296, en: http://www.politicacriminal.cl/Vol_10/n_19/Vol10N19A9.pdf [visitado el 15/09/16]; SALAZAR, Andrés. "El delito de mantención de la venta de alimentos defectuosos al público: una revisión del artículo 315 del Código Penal a partir de la teoría de las presunciones y de la dogmática de los delitos de omisión propia”, Polít. crim. n ${ }^{\circ} 19$ (Julio 2015), Art. 11, pp. 318-361, en: http://www.politicacriminal.cl/Vol_10/n_19/Vol10N19A11.pdf [visitado el 15/09/16]. Deben mencionarse también las tesis de grado de HONORES, Rodrigo, Problemas sobre la posición de garante del fabricante en la responsabilidad por el producto, Memoria para optar al grado de Licenciado en Ciencias Jurídicas y Sociales, Universidad de Chile, Santiago de Chile, 2015, y de GROSMAN, Denise, Decisiones colegiadas en la responsabilidad penal por el producto, Memoria para optar al grado de Licenciada en Ciencias Jurídicas y Sociales, Universidad de Chile, Santiago de Chile, 2016.

${ }^{10}$ Resolución del Tribunal Estadual de Aquisgrán, JZ 1971, pp. 507 ss.

${ }^{11}$ Sentencia del Tribunal Supremo Federal alemán, BGHSt 37, pp. 106 y ss.

${ }^{12}$ Sentencia del Tribunal Supremo Federal alemán, BGHSt 41, pp. 206 y ss.

${ }^{13}$ Al respecto BOCK, Barbara, Produktkriminalität und Unterlassen, Aachen: Shaker, 1997, p. 87 y ss.; EICHINGER, Harald, Die strafrechtliche Produkthaftung im deutschen im Vergleich zum angloamerikanischen Recht, Frankfurt am Main: Peter Lang, 1997, p. 141; SCHMUCKER, Andrea, Die „Dogmatik“ einer strafrechtlichen Produktverantwortung, Frankfurt am Main: Peter Lang, 2001, p. 93 y ss.

${ }^{14}$ Sobre esta cuestión en detalle véase, entre otros, BOSCH, Nikolaus, Organisationsverschulden in Unternehmen, Baden-Baden: Nomos, 2002, p. 81 y ss.; HILGENDORF, Eric, "Der gesetzmäßige Zusammenhang im Sinne der modernen Kausallehre", Jura 1995, pp. 514-522; KAUFMANN, Armin, "Tatbestandsmäßigkeit und Verur-sachung im Contergan-Verfahren Folgerungen für das geltende Recht und für die Gesetzgebung", JZ 1971, pp. 569-576, p. 572 y ss.; en Chile véase el completo trabajo de HERNÁNDEZ, Héctor, "El problema de la causalidad general”, cit. nota $\mathrm{n}^{\circ}$ 9, pp. 1-33. En materia de responsabilidad por el producto debe distinguirse entre una "causalidad general" y una "causalidad concreta". La "causalidad general" se ocupa de la pregunta de si entre el consumo del producto y los daños producidos a los bienes jurídicos de los consumidores existe una ley empírica, en el sentido de una aptitud abstracta del producto para dañar, confirmada con un alto grado de probabilidad estadística. El término "causalidad general" fue acuñado por KAUFMANN, a propósito del caso Contergan (véase KAUFMANN, Armin, "Tatbestandsmäßigkeit und Verursachung im Contergan-Verfahren Folgerungen für das geltende Recht und für die Gesetzgebung”, JZ 1971, pp. 569-576, p. 572). La "causalidad concreta", por su parte, exige verificar dos cuestiones diversas (cfr. en lo que sigue MAYER, Michael, Strafrechtliche Produktverantwortung bei
} 
CONTRERAS, Lautaro. "La posición de garante del fabricante en el Derecho penal alemán”.

determinar los deberes jurídicos que debe cumplir todo fabricante ${ }^{15}$; la cuestión de si el conocimiento de los peligros del producto puede fundar dolo o solo culpa ${ }^{16}$, y el efecto que puede tener en el injusto un acto de la Administración que autoriza la comercialización de un bien de consumo ${ }^{17}$.

En este artículo se intentará dar respuesta a una de las arduas preguntas que se presentan en materia de responsabilidad penal por el producto, a saber: cuál es el fundamento de la posición de garante del fabricante. La responsabilidad criminal de este puede hacerse efectiva a través de los tipos penales de homicidio y lesiones corporales ${ }^{18}$. La aplicación de estos tipos es procedente no solo frente a un hacer positivo del fabricante, el que tendrá lugar cuando introduzca en el mercado un producto defectuoso, sino también ante una omisión de aquel, la que se verificará cuando no advierta los peligros o no lleve a cabo la acción de retirada necesaria para evitar el acaecimiento de un resultado lesivo ${ }^{19}$. Como la tipicidad objetiva de los delitos de omisión impropia exige la concurrencia de una posición de garante ${ }^{20}$, se hace indispensable determinar cuál sería el fundamento de esta. Se trata de una cuestión que reviste importancia para el Derecho chileno, puesto que los tipos penales de homicidio simple y lesiones corporales (menos graves) también se pueden realizar por omisión, en la medida que concurra una obligación jurídica de actuar ${ }^{21}$. En este contexto,

Arzneimittelschäden Ein Beitrag zur Abgrenzung der Verantwortungsbereiche im Arzneiwesen aus strafrechtlicher Sicht, Berlin: Springer, 2008, p. 165 s.). Primero, determinar si efectivamente el contacto con el producto fue el factor causal para desencadenar el resultado, sin que existan otros elementos que puedan explicar también los daños a la vida o salud (por ejemplo, una conducta descuidada del propio consumidor). Segundo, establecer qué conductas específicas al interior de la empresa (lo que supone necesariamente distinguir entre las actuaciones de los distintos miembros de la organización empresarial) fueron las que ocasionaron - en el sentido de la teoría de la equivalencia- las muertes o lesiones de las víctimas.

${ }^{15} \mathrm{Al}$ respecto detalladamente CONTRERAS, Lautaro, Normative Kriterien zur Bestimmung der Sorgfaltspflichten des Produzenten, Berlin: Duncker \& Humblot, 2012, pp. 118 y ss.

${ }^{16}$ Al respecto EICHINGER, Die strafrechtliche Produkthaftung, cit. nota ${ }^{\circ} 13$, p. 269 ss.; HÖHFELD, Hendrik, Strafrechtliche Produktverantwortung und Zivilrecht, Berlin: Springer, 1999, pp. 163 у ss.; SCHMUCKER, Die „Dogmatik“, cit. nota ${ }^{\circ} 13$, p. 103 ss.

${ }^{17}$ Sobre el efecto en el injusto penal de las decisiones de la autoridad en materia de seguridad de productos véase MAYER, Strafrechtliche Produktverantwortung, cit. nota n ${ }^{\circ} 14$, pp. 327 y ss. con abundantes citas.

${ }^{18}$ Así ocurrió en los casos Contergan (resolución del Tribunal Estadual de Aachen, JZ 1971, pp. 507 ss.), Monza-Steel (sentencia del Tribunal Estadual de München II, en: SCHMIDT-SALZER, Joachim, Entscheidungssammlung Produkthaftung, Bd. IV: Mit einer Einführung und Urteilsanmerkungen, Strafrechtliche Entscheidungen, Gesamtregister Bd. I-IV, Berlin: Schweitzer, 1982, Nr. IV. 28, pp. 296 y ss.), del pastel de almendras (sentencia del Tribunal Supremo Federal alemán, NStE, Nr. 5 zu § 223 StGB [Mandelbienenstich], sin número de página), del espray para cuero (sentencia del Tribunal Supremo Federal alemán, $B G H S t 37$, pp. 106 y ss.) y del producto protector de madera (sentencia del Tribunal Supremo Federal alemán, $B G H S t$ 41, pp. 206 y ss.).

${ }^{19}$ Cfr. BGHSt 37, 106, 114.

${ }^{20}$ Sobre la exigencia de una posición de garante en el contexto de la tipicidad objetiva de los delitos de omisión impropia en Chile véase HERNÁNDEZ, Héctor, "Art. 1'", en: COUSO, Jaime; HERNÁNDEZ, Héctor (Editores), Código Penal comentado, Santiago de Chile: Legal Publishing, 2011, pp. 7-105, pp. 25 y ss., con abundantes citas; POLITOFF, Sergio et al, Lecciones de Derecho penal chileno Parte General, $2^{\mathrm{a}}$ edición, Santiago de Chile: Editorial Jurídica de Chile, 2004, pp. 200 y ss. Sobre la exigencia de la posición de garante en Alemania véase, por todos, KÖHLER, Michael, Strafrecht Allgemeiner Teil, Berlin: Springer, 1997, pp. 214 y ss.

${ }^{21}$ La posibilidad de sancionar en Chile al fabricante por el delito de homicidio simple del art. $391 \mathrm{~N}^{\circ} 2$ del Código Penal (en comisión por omisión) no requiere mayor explicación. En relación con las lesiones corporales solo cabría una omisión impropia respecto de las lesiones menos graves (art. 399 del Código 
Polít. crim. Vol. 12, № 23 (Julio 2017), Art. 1, pp. 1-55.

[http://www.politicacriminal.cl/Vol_12/n_23/Vol12N23A1.pdf]

resulta fundamental para el Derecho de nuestro país la discusión relativa a la justificación de la posición de garante del productor.

La sentencia del caso del espray para cuero (también denominado caso "Lederspray" o "Erdal"), pronunciada por el Tribunal Supremo Federal alemán (en adelante indistintamente "BGH") el 6 de julio de $1990^{22}$, fue la decisión que puso en evidencia las complejas dimensiones que presenta el problema de la posición de garante del fabricante ${ }^{23}$. El análisis de este caso nos permitirá centrar nuestra atención en el siguiente aspecto fundamental: es frecuente la introducción de productos en el mercado cuyos riesgos para los consumidores -en caso de ser utilizados de un modo razonable- no sean cognoscibles ni evitables para el fabricante al momento de la comercialización. Si estos riesgos de desarrollo son descubiertos con posterioridad, ¿es posible afirmar una posición de garante del fabricante que lo obligue a evitar resultados lesivos, a través de una advertencia de los peligros del producto o de su retirada del mercado? ¿Cuál debería ser la fundamentación de esta obligación de actuar? Teniendo en cuenta su enorme importancia en la materia, y el intenso debate dogmático a que dio lugar en Alemania, la sentencia del caso del espray para

Penal). Como el art. 397 de dicho Código limita el castigo de las lesiones a aquellas que se provoquen a través de las conductas de herir, golpear o maltratar, es difícilmente sostenible la posibilidad de sancionar en virtud de este artículo la conducta del fabricante que no retira del mercado un producto defectuoso o que no advierte de sus defectos (en favor, en cambio, de un interpretación amplia de las conductas típicas que pueden causar alguno de los resultados previstos en el art. 397 del Código Penal MERA, Jorge, "Los medios en el delito de lesiones graves [Art. 397 del C.P.]", Revista de Ciencias Penales, 1975, Tomo XXXIV, pp. 163-200, pp. 182 y ss.). Lo mismo puede decirse en relación al tipo penal del art. 395 del Código Penal, que emplea la voz "castrare", y al delito del 398 del mismo cuerpo normativo, que utiliza el término "administrándole", conceptos que parecen excluir una conducta omisiva del fabricante.

${ }^{22}$ BGHSt 37, pp. 106 y ss.

${ }^{23}$ En otros casos de responsabilidad penal por el producto, la jurisprudencia también abordó los problemas de la realización omisiva de los tipos penales de homicidio y lesiones por parte del fabricante, pero de un modo mucho menos pormenorizado que en el caso del espray para cuero. Así, en el caso Contergan, el Tribunal Estadual de Aquisgrán consideró la posibilidad de la realización típica de los delitos de homicidio y lesiones culposas a través de una omisión; sin embargo, no pudo dar por establecido en la vista del juicio oral de qué manera los distintos acusados habían contribuido al resultado a través de sus conductas (LG Aachen, JZ 1971, pp. 516 y s.). En este caso se podría haber considerado la existencia de una omisión contraria a deber, puesto que los acusados no retiraron el medicamento del mercado, ni advirtieron de sus peligros a los consumidores (así BRUNS, Hans-Jürgen, "Ungeklärte materiellrechtliche Fragen des Contergan-Prozesses”, en: LÜTTGER, Hans et al [Editores], Festschrift für Ernst Heinitz zum 70. Geburtstag, Berlin: Walter de Gruyter, 1972, pp. 317-340, p. 335). En el caso del producto protector de madera, el Tribunal Estadual de Fráncfort del Meno reprochó a los acusados no haber adoptado ninguna medida para advertir acerca de las características dañosas del producto o para retirarlo del mercado, estando obligados a cumplir tales deberes de conducta en virtud de una posición de garante por hacer precedente contrario a deber (LG Frankfurt am Main, ZUR 1994, p. 34; crítica respecto de la argumentación de la injerencia en este caso, sobre la base de la falta de cognoscibilidad del carácter defectuoso del producto en el momento de su comercialización SCHWARTZ, Martina, Strafrechtliche Produkthaftung Grundlagen, Grenzen und Alternativen, Frankfurt am Main: Peter Lang, 1999, p. 46 y s.). El Tribunal Supremo Federal alemán anuló la sentencia del Tribunal Estadual de Fráncfort del Meno debido a la falta de relación causal entre el uso del producto protector de la madera y los daños a la salud, sin hacerse cargo de la pregunta relativa a la posición de garante del fabricante (BGHSt 41, pp. 206 y ss.). Finalmente, en el caso del pastel de almendras, el Tribunal Supremo Federal alemán partió de la base de la existencia de una posición de garante de los acusados (sin precisar cuál sería), y estableció que estos habían actuado dolosamente porque, a pesar de conocer el carácter tóxico del producto, no desplegaron ninguna acción de advertencia o retirada motivados por razones financieras y de tiempo (sentencia del Tribunal Supremo Federal alemán, NStE, Nr. 5 zu § 223 StGB [Mandelbienenstich], sin número de página). 
CONTRERAS, Lautaro. "La posición de garante del fabricante en el Derecho penal alemán”.

cuero debe constituir el punto de partida para tratar el problema de la posición de garante del productor.

En este trabajo se describirán los hechos que dieron lugar al caso, así como los argumentos que esgrimió el tribunal de instancia y el BGH para hacer responsables a los acusados por las lesiones por omisión ocasionadas a los consumidores (infra 1). A continuación, se analizarán en detalle las objeciones que la doctrina ha planteado al razonamiento del BGH relativo a la injerencia (infra 2). Posteriormente, se expondrán las teorías alternativas que ha ofrecido la doctrina para fundar una responsabilidad por omisión del fabricante. Para ello, distinguiremos entre dos grupos de soluciones ${ }^{24}$. Por una parte, aquellas que recurren a la idea de injerencia para hacer responsable al fabricante, pero renunciando a la exigencia de la contrariedad a deber (infra 3). Por otra, aquellas que han intentado fundar el deber de evitación de resultados a través de posiciones de garante distintas al hacer precedente (infra 4). En la parte final del artículo, se desarrollará una toma de postura en torno al problema (infra 5).

\section{Los hechos del caso del espray para cuero, y el razonamiento del tribunal de instancia y del BGH para fundar una obligación de retirada.}

\subsection{Los hechos ${ }^{25}$.}

La empresa de responsabilidad limitada W\&M fabricaba esprays que servían para el cuidado de zapatos y vestimentas de cuero. El producto fue distribuido durante más de veinte años a través de las filiales E. y S., sin que se existiera queja alguna por parte de los consumidores. Mientras que la primera de las filiales vendía el aerosol a tiendas de abarrotes, supermercados y locales de productos de limpieza bajo la marca "E", la segunda filial lo comercializaba a tiendas de zapatos y cueros bajo la marca "S".

A partir de la primavera de 1980 llegaron al departamento de química de la empresa W\&M informaciones que daban cuenta de daños a la salud, atribuibles al uso del espray. Varios consumidores -que emplearon el producto de acuerdo a las instrucciones de uso- habían sufrido molestias respiratorias, tos, mareos, escalofríos y fiebre. En algunos casos, incluso, los afectados debieron ser tratados en unidades de cuidados intensivos. Normalmente, los diagnósticos indicaban que los enfermos sufrían de edemas pulmonares.

Debido a los incidentes atribuidos al uso del producto, la empresa ordenó la realización de investigaciones y adoptó un conjunto de medidas para esclarecer cuál era el componente tóxico del espray, no pudiendo identificar ningún defecto de diseño. Solo se logró establecer que, a mediados de la década de los ochenta, se había aumentado la cantidad de aceite de silicona que contenían los aerosoles. Por ello, se disminuyó la dosis de ese componente en las nuevas partidas del producto. Sin embargo, siguieron produciéndose

\footnotetext{
${ }^{24}$ Esta diferenciacción se puede encontrar ya en WEIßER, Bettina, Kausalitäts- und Täterschaftsprobleme bei der strafrechtlichen Würdigung pflichtwidriger Kollegialentscheidungen, Berlin: Duncker \& Humblot, 1996, pp. 38 y ss.

${ }^{25}$ La exposición de los hechos se hace a partir de lo que resultó acreditado en el proceso (véase BGHSt 37, 106,108 y ss.).
} 
Polít. crim. Vol. 12, № 23 (Julio 2017), Art. 1, pp. 1-55.

[http://www.politicacriminal.cl/Vol_12/n_23/Vol12N23A1.pdf]

nuevos casos de lesiones; el primero de ellos llegó a conocimiento de la empresa el 14 de febrero de 1981 (fecha que denominaremos "T1"), lo que motivó pedir asesoría a toxicólogos de dos empresas químicas y a un médico, quienes no lograron aclarar la causa de los daños a la salud que estaban sufriendo los usuarios. Posteriormente, se eliminó el aceite de silicona de la fórmula del producto; sin embargo, se produjeron nuevos casos de lesiones corporales que fueron conocidos por la empresa. Ya no se trataba solo de eventos vinculados al aerosol distribuido bajo la marca "S" -como ocurrió en un inicio-, sino que también relacionados con el producto comercializado bajo la marca "E".

El 12 de mayo de 1981 (fecha que denominaremos "T2") tuvo lugar una reunión extraordinaria donde participaron todos los directivos de la empresa W\&M. Uno de ellos, a cargo del laboratorio central -consultado en su calidad de experto en química-, indicó a los restantes que no existía indicio alguno acerca de la toxicidad del espray y, por lo tanto, no había motivo para retirar el producto del mercado. Además, recomendó encargar nuevos estudios a instituciones externas, colocar advertencias en los aerosoles que se comercializaran en el futuro y, en caso de ser necesario, mejorar las instrucciones de los productos que ya estaban en el mercado. Su propuesta fue asumida en forma unánime por los otros directivos. Existió acuerdo, además, en que una paralización de la venta del espray, o una acción de retirada o de advertencia masiva solo iba a realizarse si nuevos estudios concluían la existencia de un "verdadero defecto del producto" o de un "riesgo comprobable para los consumidores". Luego de la reunión, los directivos de las empresas filiales E. y S. fueron informados de las decisiones que se habían adoptado, siendo aprobadas por ellos. Con posterioridad a la sesión extraordinaria del 12 de mayo de 1981, tuvieron lugar nuevos casos de lesiones provocados por los esprays de las marcas E. y S. Pese a las nuevas indagaciones que se realizaron, no pudo identificarse la sustancia que estaba causando los daños a la salud. Con el transcurso del tiempo, se complementaron y mejoraron las instrucciones del producto.

Recién en septiembre de 1983, y después de la intervención del Ministerio Federal de Salud alemán, la empresa W\&M paralizó la producción de los esprays y retiró el producto del mercado.

\subsection{El razonamiento del tribunal de instancia y, en especial, del BGH para fundar una obligación de retirada de los esprays.}

Por los hechos anteriormente expuestos, cuatro ejecutivos de la empresa fabricante, y dos ejecutivos de la filiales E. y S., fueron sometidos a juicio. En los casos de lesiones corporales que tuvieron lugar después del 14 de febrero de 1981 (T1) y antes de la reunión extraordinaria del 12 de mayo de 1981 (T2), el tribunal de instancia (Tribunal Estadual de Maguncia) estimó concurrente una posición de garante de los ejecutivos, condenándolos por lesiones culposas al haber omitido la retirada oportuna del producto desde los distintos comercios (antiguo § 230, correspondiente al actual § 229, en relación al § 13, todos del Código Penal alemán).

Tratándose de los casos de lesiones que acontecieron después de la reunión extraordinaria del 12 de mayo de 1981 (T2), el tribunal consideró a los ejecutivos culpables del delito de 
CONTRERAS, Lautaro. "La posición de garante del fabricante en el Derecho penal alemán".

lesiones corporales peligrosas (antiguo $\S 223 \mathrm{a}$, actual $\S 224$, ambos del Código Penal alemán; en adelante indistintamente StGB). Respecto de este delito, se concluyó que el ilícito se había realizado a través de un hacer positivo -en la medida que nuevas partidas del producto se introdujeron en el mercado después de T2-, pero también a través de una omisión -por cuanto no se retiraron aquellos esprays que en ese momento ya se encontraban en el comercio-. El tribunal de instancia fundó la posición de garante de los acusados en deberes jurídicos reconocidos por el Derecho civil. Así, indicó que, desde el punto de vista de los deberes de aseguramiento del tráfico, correspondía a los acusados ejecutar todo lo necesario y exigible para evitar los peligros que se cernían sobre la salud de los usuarios de los esprays ${ }^{26}$. El tribunal indicó que en la jurisprudencia civil existe acuerdo en que todo fabricante tiene la obligación de vigilar los riesgos eventuales que puedan surgir del producto, después de que este sea comercializado y que, dado el caso, existe el deber de llevar a cabo acciones de advertencia y retirada ${ }^{27}$.

Los acusados dedujeron sendos recursos de casación, alegando vicios formales en el procedimiento y errores en la aplicación de normas sustantivas. El Tribunal Supremo Federal alemán confirmó la condena de casi todos ellos ${ }^{28}$, distinguiendo entre conductas activas y omisivas, pero fundando la posición de garante en consideraciones diversas a las que tuvo a la vista el tribunal de instancia. Así, indicó que los principios de responsabilidad orientados a la reparación del daño no se pueden emplear automáticamente para determinar la responsabilidad criminal, en especial cuando es posible establecer la existencia de una posición de garante conforme a principios de naturaleza propiamente penal ${ }^{29}$. El deber de evitación de resultados -señaló el BGH-surgió a partir de una conducta previa contraria a deber, estableciendo el tribunal que todo aquel que crea una situación de riesgo para terceros, a través de una conducta precedente antijurídica, está obligado a evitar los daños que puedan producirse a raíz de esa actuación ${ }^{30}$. La conducta previa consistió, concretamente, en la introducción en el mercado de los esprays protectores de cuero, que amenazaban con causar daños a la salud en caso de ser utilizados de acuerdo a su normal destino $^{31}$. Por consiguiente, el BGH estableció que los acusados deberían haber adoptado las medidas necesarias para evitar el acaecimiento del daño, las que no podían ser otras que la retirada del producto del mercado. Como los ejecutivos no cumplieron con su deber de retirada, el tribunal los condenó por lesiones por omisión.

A primera vista, el BGH es partidario en su sentencia de los límites impuestos a la idea de injerencia desarrollados por la doctrina mayoritaria ${ }^{32}$ : primero, debe existir un hacer

\footnotetext{
${ }^{26}$ LG Mainz resolución de fecha 16.01.1989, publicada en SCHMIDT-SALZER, Entscheidungssammlung, cit. nota $\mathrm{n}^{\circ} 18$, Nr. IV. 3. 22, pp. 27 y s. Sobre el significado del concepto "deberes de aseguramiento del tráfico" en el Derecho civil alemán véase infra nota ${ }^{\circ} 115$.

${ }^{27}$ LG Mainz resolución de fecha 16.01.1989, publicada en SCHMIDT-SALZER, Entscheidungssammlung, cit. nota $\mathrm{n}^{\circ} 18$, Nr. IV. 3. 22, p. 28.

${ }^{28}$ Solo el recurso de casación deducido por el director del laboratorio central de W\&M tuvo éxito, quedando este absuelto.

${ }^{29}$ BGHSt 37, 106, 115

${ }^{30}$ BGHSt 37, 106, 115

${ }^{31}$ BGHSt 37, 106, 117.

${ }^{32}$ Una exposición de los requisitos de la injerencia de acuerdo con la doctrina dominante puede encontrarse en JESCHECK, Hans-Heinrich; WEIGEND, Thomas, Lehrbuch des Strafrechts Allgemeiner Teil, $5^{\mathrm{a}}$ edición,
} 
Polít. crim. Vol. 12, № 23 (Julio 2017), Art. 1, pp. 1-55.

[http://www.politicacriminal.cl/Vol_12/n_23/Vol12N23A1.pdf]

precedente que sea objetivamente contrario a deber; segundo, es necesario que la conducta previa haya causado el peligro de acaecimiento del daño; finalmente, se requiere que la infracción a deber se funde en el quebrantamiento de una norma que sirva para la protección del bien jurídico afectado. En opinión del tribunal, estos presupuestos se reunieron en el caso en análisis, especialmente la exigencia de la contrariedad a deber ${ }^{33}$, infiriéndola de la prohibición general neminem laedere, de una interdicción de dañar respaldada constitucionalmente, y de una norma de rango legal. De este modo, fundó la infracción a deber con la comprobación de que el ordenamiento jurídico prohíbe -al menos por regla general- crear peligros de los cuales surjan daños corporales para terceros, a menos que se intervenga en el curso de los acontecimientos (principio neminem laedere) ${ }^{34}$; el fundamento jurídico de tal principio se desprendería de la protección general de que goza la integridad física en el artículo 2, párrafo 2, frase primera, de la Constitución alemana ${ }^{35}$. El tribunal agregó que los acusados también habían quebrantado el $\S 30$ número 2 de la Ley de alimentos y artículos de primera necesidad ${ }^{36}$, vigente a la época de los hechos, que prohibía poner en el mercado objetos que -por su composición- fueran idóneos para dañar la salud en caso de uso conforme a su normal destino ${ }^{37}$.

El BGH determinó la contrariedad a deber de acuerdo a una perspectiva ex post y la dedujo a partir de la desaprobación jurídica del resultado:

"La contrariedad a deber objetiva de la conducta previa no requiere que el sujeto actuante haya lesionado con ello sus deberes de cuidado, es decir, haya actuado culposamente (...); en este sentido, basta con la desaprobación jurídica del resultado de peligro. El que la conducta de aquel que ha causado tal peligro sea reprochable en el sentido de culpabilidad personal, no es relevante",38.

Finalmente, el tribunal afirmó en su sentencia que la circunstancia que ciertos cargos directivos de la empresa fabricante sean ocupados por personas distintas en el periodo comprendido entre la primera venta del producto, y el momento en que debe tomarse la decisión de su retirada, no constituye un obstáculo para afirmar una obligación de evitación de resultados. Esta obligación recaerá siempre en los ejecutivos que ejerzan sus cargos en el

Berlin: Duncker \& Humblot, 1996, p. 625; STREE, Walter, "Ingerenzprobleme", en: KOHLMANN, Günter (Editor), Festschrift für Ulrich Klug zum 70. Geburtstag, Tomo II, Berlin: Deubner, 1983, pp. 395-404, pp. 398 y s.; STREE, Walter; BOSCH, Nikolaus, "StGB § 13 Begehen durch Unterlassen”, en: Schönke/Schröder Strafgesetzbuch Kommentar, 29a edición, München: C. H. Beck, 2014, número marginal 35 y s. A favor de una aplicación de la injerencia como posición de garante en el Derecho chileno detalladamente IZQUIERDO, Cristóbal, "Comisión por omisión. Algunas consideraciones sobre la injerencia", Revista Chilena de Derecho, vol. $33 \mathrm{~N}^{\circ}$ 2, 2006, pp. 329-343; en contra de la aceptación de la injerencia en Chile, entre otros, POLITOFF, Sergio et al, Derecho penal chileno Parte Especial Delitos contra el individuo en sus condiciones físicas, $2^{\mathrm{a}}$ edición, Santiago de Chile: Editorial Jurídica de Chile, 1993, p. 60; POLITOFF et al, Lecciones de Derecho penal, cit. nota $\mathrm{n}^{\circ} 20$, pp. 202 y ss.

${ }^{33}$ BGHSt, 37, 106 117: "Los requisitos de una posición de garante semejante, que obliga a la evitación del resultado, fueron establecidos de un modo exento de error jurídico por la cámara penal en el presente caso".

${ }^{34}$ BGHSt, 37, 106, 117.

${ }^{35}$ BGHSt, 37, 106, 117.

${ }^{36}$ Lebensmittel- und Bedarfsgegenständegesetz (LMBG).

${ }^{37}$ BGHSt 37, 106, 117.

${ }^{38}$ BGHSt 37, 106, 118 y s. 
CONTRERAS, Lautaro. "La posición de garante del fabricante en el Derecho penal alemán”.

momento en que deben adoptarse las medidas de evitación. Y es que aquel que comienza a ejercer funciones en una empresa -indicó el tribunal- "entra" generalmente en la posición de garante que recaía en el predecesor, a través de la asunción de las tareas que desempeñaba este ${ }^{39}$.

\section{Crítica de la doctrina a la argumentación del BGH en el caso del espray para cuero.}

A continuación se expondrán los cuestionamientos de la doctrina alemana a la argumentación del BGH sobre la posición de garante del fabricante. Se trata de reparos acerca del modo en que el tribunal fundó la contrariedad a deber de la conducta previa de los acusados (infra 2.1), críticas en contra del razonamiento acerca de la cognoscibilidad del carácter peligroso del hacer precedente (infra 2.2) y objeciones respecto de la transferibilidad de los deberes de garante fundados en la injerencia, en caso de variación en la integración de la directiva de la empresa (infra 2.3). Es importante aclarar que se trata de críticas a las razones que dio el BGH para fundar una posición de garante del fabricante; la dogmática alemana no cuestiona el resultado al que el tribunal llegó, a saber: que sobre el fabricante pesa una obligación jurídica de actuar.

\subsection{El fundamento de la contrariedad a deber de la conducta.}

Como ya se adelantó, el BGH esgrimió como argumento para fundar la contrariedad a deber de la conducta previa de los acusados que estos habían infringido la prohibición general de dañar a otros, contenida en el principio neminem laedere; lo prescrito en el artículo 2, párrafo 2, frase primera, de la Constitución alemana, así como la regla del $\S 30$ número 2 de la (hoy derogada) Ley de alimentos y artículos de primera necesidad.

La doctrina indica que, si bien la fórmula general neminem laedere -“está prohibido crear peligros de los cuales surjan daños corporales para terceros, a menos que se intervenga en el curso de los acontecimientos"- es mencionada en ocasiones para fundar los deberes de garante basados en el hacer precedente peligroso ${ }^{40}$, la referencia que hizo el BGH a esta prohibición -vacía de contenido específico- no es capaz de indicarnos en qué casos el sujeto está obligado a eliminar los peligros creados a través de su actuar previo ${ }^{41}$. Conforme a la idea del neminem laedere, cualquier conducta precedente que haya sido causa de un resultado podría dar origen a una obligación jurídica de evitar el mismo ${ }^{42}$, con total independencia de su carácter desaprobado o no. Considerando su absoluta falta de contornos, la prohibición de dañar a otros no permite fundar la contrariedad a deber de la conducta peligrosa en un caso de injerencia. Pero además, tal prohibición no se encuentra positivizada de modo general e ilimitado en el Derecho vigente, ni tampoco este prevé

\footnotetext{
${ }^{39}$ BGHSt 37, 106, 120.

${ }^{40}$ Así, por ejemplo JESCHECK; WEIGEND, Lehrbuch des Strafrechts, cit. nota n 32, p. 625: "El deber de garante procedente del hacer peligroso previo se funda en la prohibición de lesionar a otros (neminem laedere)"; KÜHL, Kristian, Strafrecht Allgemeiner Teil, $7^{a}$ edición, München: Vahlen, 2012, § 18, número marginal 91 (nota al pie 197); ROXIN, Claus, Strafrecht Allgemeiner Teil, Tomo 2, München: C. H. Beck, $2003, \S 32$, número marginal 146.

${ }^{41}$ Véase STREE; BOSCH, "StGB § 13”, cit. nota n 32, número marginal 32.

${ }^{42}$ En este sentido BOSCH, Organisationsverschulden, cit. nota n 14, p. 192 (pie de página 633).
} 
Polít. crim. Vol. 12, № 23 (Julio 2017), Art. 1, pp. 1-55.

consecuencias jurídicas frente a su incumplimiento ${ }^{43}$. Los sistemas del Derecho civil y penal no contemplan una cláusula general de responsabilidad frente a la infracción de una prohibición de dañar a otros, sin tomar en consideración el carácter desaprobado de la conducta enjuiciada o determinados elementos subjetivos ${ }^{44}$.

El deber del fabricante de impedir el resultado tampoco se puede derivar de la protección a la integridad física, prevista en el artículo 2, párrafo $2^{\circ}$, frase primera de la Constitución alemana $^{45}$. Sin perjuicio de que de tal norma no es posible inferir ninguna expectativa de conducta idónea para la protección de los bienes jurídicos de los consumidores, cabe señalar que los derechos fundamentales fueron concebidos en sus inicios como medios de protección frente a los abusos del poder estatal, asegurando esferas de libertad individual ${ }^{46}$. Los derechos constitucionales representan -ante todo- facultades de defensa del ciudadano de carácter negativo, esto es, límites establecidos en favor del particular frente a posibles afectaciones de bienes jurídicos cometidas por órganos del Estado ${ }^{47}$. Los deberes de evitación de resultados que pueden resultar de la injerencia obligan, al menos en la casi totalidad de los casos, solo a particulares, y no a funcionarios públicos. Incluso si se aceptara la denominada "eficacia horizontal de los derechos fundamentales"48 lo cierto es que normas como las del artículo 2, párrafo $2^{\circ}$, frase primera de la Constitución alemana, no están configuradas como reglas de conducta que rijan la vida cotidiana y, por lo tanto, no son aptas para valorar si una determinada actuación previa quebrantó o no el deber jurídico que regía en la respectiva situación. Por lo expuesto, el fundamento de un deber de garante por injerencia no puede buscarse en el catálogo de derechos constitucionales.

Para fundar la injerencia en el caso del espray de cuero, la remisión a preceptos de la Ley de alimentos y artículos de primera necesidad también resulta insatisfactoria. Como se dijo, el BGH declaró que la contrariedad a deber objetiva de la conducta previa de los acusados se basaba en la infracción al $§ 30$ número 2 de dicha ley, conforme al cual estaba prohibido poner en el mercado bienes dañinos para la salud ${ }^{49}$. Sin embargo, dicho precepto no contenía ninguna norma de conducta específica que un fabricante de aerosoles debía cumplir para evitar lesiones a los bienes jurídicos de los consumidores (como por ejemplo: la prohibición de utilizar ciertas sustancias en el producto o la obligación de someterlo a determinadas pruebas). Esta disposición legal se limitaba a describir un resultado -el daño

\footnotetext{
${ }^{43}$ BRAMMSEN, Joerg, "Strafrechtliche Rückrufpflichten bei fehlerhaften Produkten?”, GA 1993, pp. 97-120, p. 103.

${ }^{44}$ Cfr. BRAMMSEN, "Strafrechtliche Rückrufpflichten”, cit. nota ${ }^{\circ} 43$, p. 103.

${ }^{45}$ Según esta norma: "Toda persona tiene derecho a la vida y a la integridad física".

${ }^{46}$ Así ZIPPELIUS, Reinhold; WÜRTENBERGER, Thomas, Deutsches Staatsrecht Ein Studienbuch, $31^{\mathrm{a}}$ edición, München: C. H. Beck, 2005, p. 168; en el mismo sentido HUFEN, Friedhelm, Staatsrecht II Grundrechte, $4^{\mathrm{a}}$ edición, München: C. H. Beck, 2014, § 7, número marginal 8.

${ }^{47}$ Así BRAMMSEN, "Strafrechtliche Rückrufpflichten”, cit. nota n 43, p. 104.

${ }^{48}$ Bajo la expresión "eficacia horizontal" ("Drittwirkung") se plantea la pregunta si -y bajo qué circunstancias- los derechos fundamentales rigen no solo en la "relación vertical" entre Estado y ciudadano, sino también en el "plano horizontal" entre particulares. Una eficacia horizontal directa de los derechos fundamentales entre particulares se tiende a rechazar en la dogmática constitucional alemana puesto que ello supondría convertir derechos a la libertad del ciudadano en un orden general de conducta; por regla general, los particulares deban ser solo titulares de derechos fundamentales, no sujetos vinculados por estos (así HUFEN, Staatsrecht II, cit. nota $\mathrm{n}^{\circ} 46, \S 7$, número marginal 8).

${ }^{49}$ BGHSt 37, 106, 117.
} 
CONTRERAS, Lautaro. "La posición de garante del fabricante en el Derecho penal alemán”.

a la salud provocado por bienes de consumo- que formaba parte del tipo penal de lesiones corporales $\mathrm{y}$, en consecuencia, no era apta para valorar si la conducta previa de los acusados se había ajustado o no a las exigencias del ordenamiento jurídico ${ }^{50}$. De esta manera, el BGH determinó el riesgo de acaecimiento de daños a la salud desde una perspectiva ex post, desaprobando el hacer previo solo porque había sido causal para un resultado típicamente relevante a la luz del antiguo $§ 223$ a del Código Penal alemán (actual $\S 224)^{51}$. El empleo de esta perspectiva para establecer la contrariedad a deber del actuar precedente constituye el objeto de las principales críticas de la doctrina al fallo, las que serán expuestas a continuación.

\subsection{La cognoscibilidad del peligro de la conducta previa contraria a deber.}

Según el BGH, para afirmar la contrariedad objetiva al deber de la conducta previa de los acusados bastaba con que el resultado de puesta en peligro fuera desaprobado jurídicamente; la cuestión de si la conducta era reprochable en el sentido de la culpabilidad personal era algo irrelevante para el enjuiciamiento ${ }^{52}$. De esta manera, el tribunal determinó la infracción al deber jurídico desde una perspectiva ex post, teniendo en cuenta solamente- el resultado del peligro creado por los ejecutivos ${ }^{53}$.

\footnotetext{
${ }^{50}$ Así BOSCH, Organisationsverschulden, cit. nota $\mathrm{n}^{\circ}$ 14, p. 201. Sobre la inidoneidad (y, por tanto, ilegitimidad) de las normas de conducta en la responsabilidad por el producto que establecen meras prohibiciones de causación de resultados véase DOMEIER, Danja, Gesundheitsschutz und Lebensmittelstrafrecht, Frankfurt am Main: Peter Lang, 1999, pp. 40 y s., así como REUS, Katharina, Das Recht in der Risikogesellschaft Der Beitrag des Strafrechts zum Schutz vor modernen Produktgefahren, Berlin: Duncker \& Humblot, 2010, p. 84.

${ }^{51}$ Como señala Bosch, este tipo de estructuras de argumentación son frecuentes en la práctica jurisprudencial alemana, especialmente en el ámbito del Derecho penal alimentario (BOSCH, Organisationsverschulden, cit. nota $\mathrm{n}^{\circ} 14$, p. 201). Allí, al buscarse cuál es el deber de cuidado que debe infringirse para sancionar la puesta en el mercado negligente de alimentos peligrosos, los tribunales afirman que tal deber consiste en evitar poner en el mercado alimentos peligrosos y que, por lo tanto, quien ha introducido en el mercado tales alimentos ha infringido el deber de cuidado (véase en detalle sobre este problema HUFEN, Friedhelm, Verfassungsrechtliche Maßstäbe und Grenzen lebensmittelstrafrechtlicher Verantwortung Zur Bestimmtheit, Differenziertheit und Verhältnismäßigkeit berufsregelnder Risikoverteilung, Baden-Baden: Nomos, 1987, pp. 75 y s.). Este tipo de razonamiento circular deja sin analizar un aspecto fundamental para cualquier sistema que pretenda orientar eficazmente conductas con miras a la protección de bienes jurídicos, a saber: si acaso la actuación u omisión concreta del sujeto ha cumplido o no prohibiciones o mandatos específicos impuestos legítimamente por el Derecho para el resguardo de tales bienes.

${ }^{52}$ BGHSt 37, 106, 119.

${ }^{53}$ Críticos respecto de la perspectiva ex post para calificar la contrariedad a deber del hacer precedente en el caso del espray para cuero BOCK, Produktkriminalität, cit. nota $\mathrm{n}^{\circ} 13$, pp. 132 y s.; BOSCH, Organisationsverschul-den, cit. nota $\mathrm{n}^{\circ}$ 14, pp. 197 y ss.; DREHER, Meinrad, "Die persönliche Verantwortlichkeit von Geschäftsleitern nach außen und die innergesellschaftliche Aufgabenteilung", ZGR 1992, pp. 22-63, p. 47; HILGENDORF, Eric, Strafrechtliche Produzentenhaftung in der ,, Risikogesellschaft “, Berlin: Duncker \& Humblot, 1993, pp. 137 y s.; HÖHFELD, Strafrechtliche Produktverantwortung, cit. nota $\mathrm{n}^{\circ}$ 16, p. 130; KUHLEN, Lothar, "Strafhaftung bei unterlassenem Rückruf gesundheitsgefährdender Produkte Zugleich Anmerkung zum Urteil des BGH vom 6. 7. 1990 - 2 StR 549/89 (NStZ 1990, 588)", NStZ 1990, pp. 566-570, p. 568; OTTO, Harro, "Die strafrechtliche Haftung für die Auslieferung gefährlicher Produkte", en: WEIGEND, Thomas; KÜPPER, Georg (Editores), Festschrift für Hans Joachim Hirsch zum 70. Geburtstag am 11. April 1999, Berlin: Walter de Gruyter, 1999, pp. 291-312, p. 303 y ss.; PUPPE, Ingeborg, “Anmerkungen zu BHGSt 37, 106”, JR 1992, pp. 30-34, p. 30; SCHMUCKER, Die „Dogmatik“, cit. nota n 13, p. 121; SCHÜNEMANN, Bernd, "Zum gegenwärtigen Stand der Dogmatik der Unterlassungsdelikte in
} 
Polít. crim. Vol. 12, № 23 (Julio 2017), Art. 1, pp. 1-55.

[http://www.politicacriminal.cl/Vol_12/n_23/Vol12N23A1.pdf]

Para la doctrina dominante en materia de injerencia ${ }^{54}$, a la que el BGH dice adherir en su resolución, el actuar precedente debe ser contrario a deber desde un punto de vista objetivo, no siendo necesario -adicionalmente- que revista el carácter de culpable. En otras palabras, para fundar la posición de garante basta con que el hacer previo haya quebrantado un deber jurídico, no exigiéndose la cognoscibilidad subjetiva de la respectiva infracción. En su decisión, el BGH acierta en restar importancia a la reprochabilidad personal para fundar la posición de garante por injerencia, pero constata la contrariedad al deber desde una perspectiva de enjuiciamiento equivocada.

En efecto, la contrariedad objetiva al deber supone la creación de un riesgo desaprobado ex $a_{n t e}{ }^{55}$. Desde la perspectiva de un observador imparcial situado en el lugar del garante, las circunstancias causantes del peligro tienen que haber sido previsibles en el momento de realizar la acción previa; de lo contrario, se impondría al sujeto un deber protegido penalmente sin que este tenga la posibilidad de disminuir o eliminar los riesgos que fundan la obligación de evitar el resultado ${ }^{56}$. La previsibilidad objetiva, entendida como exigencia necesaria de la contrariedad a deber, es una consecuencia ineludible de la teoría del injusto de conducta determinable solo ex ante ${ }^{57}$. Conforme a esta teoría, el objeto de las prohibiciones de conducta solo pueden ser aquellas actuaciones que -antes de su realización y de acuerdo a la experiencia de vida- pueden afectar posiblemente, o con una probabilidad rayana en la certeza, el respectivo bien jurídico protegido ${ }^{58}$. Esta concepción, dominante hoy en el Derecho penal ${ }^{59}$, se basa en la idea de que la función de los deberes jurídicos consiste en dirigir la conducta humana para, de este modo, resguardar determinados intereses o valores dignos de protección. Tal tarea solo se puede lograr si los deberes jurídicos rigen en un momento en que sea posible para el destinatario ajustar su

Deutschland", en: GIMBERNAT, Enrique et al (Editores), Internationale Dogmatik der objektiven Zurechnung und der Unterlassungsdelikte, Heidelberg: Müller, 1995, pp. 49-82, p. 69.

${ }^{54}$ Véase por ejemplo JESCHECK; WEIGEND, Lehrbuch des Strafrechts, cit. nota n ${ }^{\circ} 32$, p. 625; SAMSON, Erich, "Probleme strafrechtlicher Produkthaftung", StV 1991, pp. 182-186, p. 184; STREE; BOSCH, "StGB § 13 ", cit. nota ${ }^{\circ} 32$, número marginal 38.

${ }_{55}$ Así KUHLEN, "Strafhaftung bei unterlassenem Rückruf", cit. nota n 53, p. 568; SAMSON, "Probleme", cit. nota $\mathrm{n}^{\circ} 54$, p. 184. Incluso para los partidarios de la injerencia como conducta previa que genera un riesgo incrementado, las circunstancias que hacen especialmente riesgosa la actuación precedente deben ser conocibles en el momento de la acción, puesto que un curso dañoso ex ante objetivamente imprevisible representa una desgracia no imputable (así JAKOBS, Günther, Strafrecht Allgemeiner Teil, $2^{\mathrm{a}}$ edición, Berlin: Walter de Gruyter, 1991, Sección 29, número marginal 42 con nota 93a, quien, sin embargo, acepta una posición de garante en el caso del espray para cuero).

${ }^{56}$ Así BOSCH, Organisationsverschulden, cit. nota n ${ }^{\circ}$ 14, p. 198.

${ }^{57}$ KUHLEN, "Strafhaftung bei unterlassenem Rückruf", cit. nota n ${ }^{\circ} 53$, p. 568.

${ }^{58}$ FREUND, Georg, "Täuschungsschutz und Lebensmittelstrafrecht - Grundlagen und Perspektiven”, ZLR 1994, pp. 261-304, p. 263; KUHLEN, "Strafhaftung bei unterlassenem Rückruf", cit. nota n 53, p. 568. Esto también rige respecto de los mandatos jurídicos, que constituyen deberes de conducta que obligan a observar ciertas posibilidades de salvación, descritas de modo concreto, y que se presentan siempre desde una perspectiva ex ante para el bien jurídico amenazado (en este sentido RUDOLPHI, Hans-Joachim, "Der Zweck staatlichen Strafrechts und die strafrechtlichen Zurechnungsformen", en: SCHÜNEMANN, Bernd [Editor], Grundfragen des modernen Strafrechtssystems, Berlin: Walter de Gruyter, 1984, pp. 69-84, pp. 76 y s.).

${ }^{59}$ En este sentido FRISCH, Wolfgang, Tatbestandsmäßiges Verhalten und Zurechnung des Erfolgs, Heidelberg: Müller, 1988, p. 71 y ss. con abundantes referencia; KUHLEN, "Strafhaftung bei unterlassenem Rückruf", cit. nota n ${ }^{\circ}$ 53, p. 568; OTTO, "Die strafrechtliche Haftung", cit. nota n ${ }^{\circ}$ 53, p. 304. 
CONTRERAS, Lautaro. "La posición de garante del fabricante en el Derecho penal alemán”.

comportamiento a los mismos; la misión se vería frustrada si tales deberes se refirieran a un instante en que la conducta regulada ya se hubiera desplegado ${ }^{60}$.

A la luz de la teoría del injusto de conducta determinable ex ante, la introducción en el mercado de los aerosoles solo podía haber sido considerada como contraria a deber si la peligrosidad del producto hubiera sido cognoscible para los acusados en el momento de tal introducción. Pero esto solo se podía afirmar respecto de aquellas partidas que siguieron comercializándose después del cambio de fórmula del producto y luego de que llegara a conocimiento de la empresa nuevas reclamaciones (esto es, después de la fecha que anteriormente denominamos como "T1") ${ }^{61}$. Con anterioridad, difícilmente puede considerarse que la peligrosidad fuera previsible, en atención a que el producto se había distribuido durante años sin que se produjera ningún incidente conocido por la empresa.

Ahora bien, en el proceso penal no se pudo comprobar si las partidas, que no fueron retiradas del mercado y que fundaron la responsabilidad por omisión impropia de los ejecutivos, habían sido comercializadas con posterioridad a T1. Una aplicación estricta del principio in dubio pro reo hubiera obligado a suponer que las lesiones a los consumidores habían sido causadas por productos comercializados incluso antes de que el peligro fuera cognoscible ${ }^{62}$. Pese a ello, el BGH afirmó que el actuar precedente había sido contrario al deber:

“...de esta manera fracasa el reparo planteado por el recurrente $S$. en el sentido de que la impresión acerca de la peligrosidad de los esprays para cuero se consolidó, en el mejor de los casos, después de la reunión de los ejecutivos, de tal manera que la venta posterior del producto y su mantención en el comercio pudo aparecer como contraria a deber. La infracción del deber objetivo por parte de la conducta previa no presupone que el agente haya lesionado sus deberes de cuidado, es decir, que se haya comportado imprudentemente (...). En este sentido, basta la desaprobación jurídica del resultado de puesta en peligro. $" 63$.

Existe acuerdo en la doctrina alemana de que, con la argumentación recién expuesta, el tribunal prescindió en realidad de la exigencia de la contrariedad objetiva a deber del hacer precedente $^{64}$. Porque ya no se puede hablar de tal contrariedad si la peligrosidad de los

\footnotetext{
${ }^{60}$ Así MIR, Santiago, "Die ex ante - Betrachtung im Strafrecht”, en: VOGLER, Theo (Editor), Festschrift für Hans-Heinrich Jescheck zum 70. Geburtstag, Tomo I, Berlin: Duncker \& Humblot, 1985, pp. 337-356, p. 338; MÜNZBERG, Wolfgang, Verhalten und Erfolg als Grundlagen der Rechtswidrigkeit und Haftung, Frankfurt am Main: Klostermann, 1966, p. 64.

${ }^{61}$ Expresamente HASSEMER, Winfried, Produktverantwortung im modernen Strafrecht, $2^{\mathrm{a}}$ edición, Heidelberg: Müller, 1996, p. 56; KUHLEN, “Strafhaftung bei unterlassenem Rückruf”, cit. nota n 53, p. 568. ${ }^{62}$ Cfr. KUHLEN, "Strafhaftung bei unterlassenem Rückruf”, cit. nota ${ }^{\circ} 53$, p. 568.

${ }^{63}$ BGHSt 37, 106, 118 y s. (el destacado es nuestro).

${ }^{64}$ En este sentido BEULKE, Werner; BACHMANN, Gregor, "Die Lederspray-Entscheidung - BGHSt 37, 106”, JuS 1992, pp. 737-744, p. 739; BOCK, Produktkriminalität, cit. nota ${ }^{\circ}$ 13, p. 133; BODE, BerndDieter, "Zur strafrechtlichen Produkthaftung", en: GEI $\beta$, Karlmann et al (Editores), Festschrift aus Anlaß des fünfzigjährigen Bestehens von Bundesgerichtshof, Bundesanwaltschaft und Rechtsanwaltschaft beim Bundesgerichtshof, Köln: Carl Heymanns, 2000, pp. 515-529, p. 523; DEUTSCHER, Jörg; KÖRNER, Peter, "Die strafrechtliche Produktverantwortung von Mitgliedern kollegialer Geschäftsleitungsorgane", wistra 1996, pp. 292-302 y 327-334, p. 299; FREUND, Georg, "StGB § 13 Begehen durch Unterlassen”, en:
} 
Polít. crim. Vol. 12, № 23 (Julio 2017), Art. 1, pp. 1-55.

[http://www.politicacriminal.cl/Vol_12/n_23/Vol12N23A1.pdf]

aerosoles no era cognoscible en el momento de su introducción en el mercado, sustentándose la argumentación únicamente en la desaprobación jurídica del resultado producido. Si se exige la contrariedad objetiva a deber del hacer precedente, entonces esta necesariamente debe fundarse a través de una perspectiva ex ante, sin que se pueda invocar el resultado del curso causal vinculado a la actuación previa.

\subsection{La transferencia del deber de garante por injerencia en caso de cambio en la integración de la directiva de la empresa.}

La debilidad del razonamiento del $\mathrm{BGH}$, en lo concerniente a la injerencia, se intensifica cuando este sostiene la posibilidad de transferencia interpersonal del deber de evitación del resultado en caso de cambio en la integración de la directiva de la empresa. En el campo de la responsabilidad penal por el producto es frecuente que, entre el momento de la introducción en el mercado de los respectivos bienes de consumo y la fecha en que ha de ejecutarse la necesaria acción de advertencia o retirada, transcurra un lapso de tiempo más o menos prolongado ${ }^{65}$. En ese intervalo es perfectamente posible que la integración del cuerpo directivo haya variado, surgiendo la pregunta entonces de si los deberes por injerencia nacidos de la comercialización previa alcanzan o no a los "nuevos" ejecutivos. Para el BGH, aquel que ingresa a la empresa se coloca normalmente en la posición de garante del predecesor, a través de una asunción de tareas ${ }^{66}$. El tribunal agrega que el ejecutivo que ha cesado en sus funciones no se libera de su posición de garante, aunque sus deberes queden limitados a lo que una persona ajena a la empresa pueda hacer para evitar el resultado $^{67}$. La postura del tribunal en torno a los deberes de garante que pesan sobre los "nuevos" directivos ha sido objeto de intensa crítica ${ }^{68}$. Al respecto se ha señalado que, si bien es cierto que el nuevo ejecutivo que se incorpora a una empresa asume los deberes

JOECKS, Wolfgang; MIEBACH, Klaus (Editores), Münchener Kommentar zum Strafgesetzbuch, Tomo 1, $2^{\mathrm{a}}$ edición, München: C. H. Beck, 2011, número marginal 129; HILGENDORF, Strafrechtliche Produzentenhaftung, cit. nota $\mathrm{n}^{\circ}$ 53, p. 140; KÜHL, Strafrecht, cit. nota $\mathrm{n}^{\circ} 40, \S 18$, número marginal 103; KUHLEN, "Strafhaftung bei unterlassenem Rückruf", cit. nota $n^{\circ}$ 53, p. 568; SAMSON, "Probleme", cit. nota $\mathrm{n}^{\circ}$ 54, p. 184. Según Puppe, la argumentación del BGH relativa a la contrariedad a deber de la conducta previa constituye una fórmula incoherente, "porque si la peligrosidad del hacer precedente ya implica su contrariedad a deber, ¿qué función y qué sentido tiene la exigencia de la contrariedad a deber?" (PUPPE, "Anmerkungen zu BHGSt 37, 106", cit. nota ${ }^{\circ}$ 53, p. 30). En el caso del producto protector de madera el Tribunal Estadual de Fráncfort del Meno también dedujo la existencia de conducta previa creadora de peligros a partir de un curso causal determinado ex post: "La conducta previa creadora de peligros de ambos acusados consistió en que ofrecieron un producto protector de madera para aplicar en espacios interiores, que causó daños a la salud también en caso de utilización conforme a su fin (...)" (LG Frankfurt am Main, ZUR 1994, p. 34). Con todo, y a diferencia del caso del espray para cuero, aquí sí existían antecedentes para sustentar la contrariedad a deber (información sobre daños previos causados por el producto y pericia de un toxicólogo) (cfr. BOSCH, Organisationsverschulden, cit. nota n ${ }^{\circ}$ 14, p. 197 con nota al pie 647).

${ }^{65}$ Así lo destaca HÖHFELD, Strafrechtliche Produktverantwortung, cit. nota $\mathrm{n}^{\circ}$ 16, p. 136. Este lapso de tiempo más o menos prolongado se explica, por ejemplo, por la existencia de bienes de consumo que no tienen una fecha de caducidad cercana o que están inmersos en largos procesos de distribución.

${ }^{66}$ BGHSt 37, 106, 120.

${ }^{67}$ BGHSt 37, 106, 120.

${ }^{68}$ Véase BOSCH, Organisationsverschulden, cit. nota $\mathrm{n}^{\circ}$ 14, pp. 214 y ss.; BRAMMSEN, Joerg, "Strafrechtliche Rückrufpflichten", cit. nota $\mathrm{n}^{\circ}$ 43, p. 111; HÖHFELD, Strafrechtliche Produktverantwortung, cit. nota ${ }^{\circ}$ 16, pp. 136 y ss.; OTTO, "Die strafrechtliche Haftung", cit. nota $\mathrm{n}^{\circ}$ 53, pp. 294 y s. 
CONTRERAS, Lautaro. "La posición de garante del fabricante en el Derecho penal alemán”.

jurídicos vinculados a la función o rol que ejercía el predecesor, la transferencia de deberes encuentra sus límites donde la respectiva obligación jurídica tiene un sustrato altamente personal, como ocurre, justamente, con los deberes fundados en la injerencia ${ }^{69}$.

En efecto, en la posición de garante por actuar precedente el sujeto amplía su espacio de libertad más allá de la medida tolerada por el Derecho ${ }^{70}$ y ocasiona, a través de su comportamiento autorresponsable, un peligro de lesión para bienes jurídicos ajenos. En la medida que los resultados dañosos todavía puedan ser impedidos, el individuo está obligado a eliminar los peligros surgidos de su propio actuar ${ }^{71}$. El fundamento base para la construcción de la injerencia se erige siempre sobre una conducta previa personal y libre. El garante por hacer precedente responde de un resultado dañoso debido a que de su propia conducta surgió el peligro que se realizó en el resultado ${ }^{72}$. En atención al vínculo indisoluble entre actuar anterior y deber de evitación, se afirma que de la posición de garante por injerencia nacen mandatos de carácter altamente personal, que no pueden transferirse a terceros ${ }^{73}$. La imposición de un deber de garante al nuevo miembro de la organización que reemplaza al anterior infringiría, además, el principio de autorresponsabilidad $^{74}$. Conforme a este principio, el ámbito de responsabilidad de cada

${ }^{69}$ Cfr. BRAMMSEN, Joerg, "Strafrechtliche Rückrufpflichten", cit. nota ${ }^{\circ}$ 43, p. 111; HÖHFELD, Strafrechtli-che Produktverantwortung, cit. nota $\mathrm{n}^{\circ}$ 16, p. 136. Con todo, en el Derecho penal ambiental alemán se ha estimado como posible que un funcionario público asuma una responsabilidad por injerencia sobre la base del rol que desempeña en la organización (estatal). De este modo, si un empleado ha dictado contra Derecho un acto administrativo que permite ciertas emisiones contaminantes, surgiría una posición de garante por injerencia, la que también recaería sobre el funcionario que reemplazó en el cargo a aquel que dictó el acto antijurídico (en este sentido expresamente HORN, Eckhard, "Strafbares Fehlverhalten von Genehmigungs- und Aufsichtsbehörden?”, NJW 1981, pp. 1-11, p. 6: el garante siempre es el funcionario en tanto "autoridad", sin que deba exitir una coincidencia entre el sujeto que ha abierto la fuente de peligro y el nuevo funcionario; también MEINBERG, Volker, “Amtsträgerstrafbarkeit bei Umweltbehörden”, NJW 1986, pp. 2220-2228, p. 2224). De este modo, para la imposición del deber de garante por injerencia prevalece en materia ambiental un punto de vista referido únicamente al cargo que se ocupa, lo que parece ser incompatible con los principios de la responsabilidad individual que deben regir en el Derecho penal (cfr. BOSCH, Organisationsverschulden, cit. nota $\mathrm{n}^{\circ} 14$, p. 215 con pie de página 708).

${ }^{70}$ En tanto se considere, como lo hace la doctrina mayoritaria (véase supra nota $n^{\circ} 32$ ), que el hacer precedente tiene que ser contrario a deber.

${ }^{71}$ Así JASCH, Michael, “Übernahme von Garantenpflichten aus Ingerenz?”, NStZ 2005, pp. 8-13, p. 11.

${ }^{72}$ Véase JASCH, “Übernahme”, cit. nota $n^{\circ} 71$, p. 11; STREE, "Ingerenzprobleme”, cit. nota n ${ }^{\circ} 32$, p. 398.

${ }^{73}$ Contra la posibilidad de transferir a un tercero los deberes de de garante por injerencia se pronuncian, entre otros, JASCH, "Übernahme", cit. nota $n^{\circ} 71$, pp. 8 y ss.; OTTO, Harro, Grundkurs Strafrecht, $7^{\mathrm{a}}$ edición, Berlin: Walter de Gruyter, 2004, § 9, número marginal 83; RADTKE, Henning, "StGB § 14 Handeln für einen anderen", en: JOECKS, Wolfgang; MIEBACH, Klaus (Editores), Münchener Kommentar zum Strafgesetzbuch, Tomo 1, 2a edición, München: C. H. Beck, 2011, número marginal 42. En oposición a lo afirmado por la doctrina, el BGH dejó abierta la posibilidad de la asunción de una posición por injerencia en un caso en que el dueño de un burdel lesionó de gravedad a un cliente, dejándolo después a cargo de un empleado del lugar, quien habría tenido el deber de evitación del resultado (BGH NStZ 2003, p. 259 y s.). Para Kühl esta decisión del BGH es incompatible con el principio de responsabilidad en materia de injerencia, que otorga una importancia gravitante a la acción previa personal del garante (KÜHL, Strafrecht, cit. nota ${ }^{\circ}$ $40, \S 18$, número marginal 121 ).

${ }^{74}$ Acerca de los límites impuestos por el principio de autorresponsabilidad al deber de evitación de resultados véase BOSCH, Organisationsverschulden, cit. nota $\mathrm{n}^{\circ}$ 14, p. 216; BRAMMSEN, "Strafrechtliche Rückrufpflich-ten", cit. nota $n^{\circ} 43$, p. 111. En este mismo sentido Jasch, quien, además, sostiene que la imposición a un tercero de un deber de garante por hacer precedente supondría obviar la exigencia de la relación de contrariedad al deber en la injerencia, según la cual el resultado de la omisión impropia debe ser 
Polít. crim. Vol. 12, № 23 (Julio 2017), Art. 1, pp. 1-55.

individuo debe limitarse, por regla general, a su propia actuación y solo bajo circunstancias particulares abarcaría la de terceros ${ }^{75}$. La transferencia de un deber por injerencia al nuevo ejecutivo implicaría hacerlo responsable por el acaecimiento de un resultado cuyo origen está en el incorrecto ejercicio previo de la libertad de actuación de un tercero, y a cuyo respecto no se tuvo ninguna capacidad de influencia. Pero además, tal transferencia también ofrece reparos de índole político-criminal porque ella importaría someter al nuevo directivo a cargas excesivas, que no le permitirían concentrarse adecuadamente en la labor que asume. Porque si el ejecutivo tuviera que contar siempre con la posibilidad de que se le haga responsable penalmente por la conducta previa de su predecesor, entonces debería suspender su actividad para examinar concienzudamente todas y cada una de las actuaciones del ejecutivo anterior, de modo tal de verificar si este quebrantó o no algún deber jurídico desencadenante de un curso causal lesivo ${ }^{76}$.

Queda por responder la pregunta si el nuevo ejecutivo puede ser responsable por una omisión impropia, no ya sobre la base de una injerencia "derivada" del predecesor, sino a partir de la asunción voluntaria de una función de protección. Existe acuerdo en la doctrina en que la asunción voluntaria de deberes de aseguramiento puede fundar una posición de garante $^{77}$. Se podría plantear que el "nuevo" ejecutivo está obligado a adoptar medidas de evitación en aquellos casos en que acepta conscientemente proteger los bienes jurídicos de los consumidores frente al garante original por injerencia (el directivo saliente). Sin embargo, un elemento fundamental de cualquier deber de garante por asunción es el establecimiento de un vínculo de confianza entre el sujeto que ya es garante frente a terceros, por una parte, y el individuo que pretende asumir la labor de protección, por otra $^{78}$. Es esa confianza justamente la que permite a quien ya es garante dejar a un lado los esfuerzos para evitar el resultado, los que serán desplegados en adelante por quien asume la labor de protección ${ }^{79}$. Pero en los casos de cambio en la integración de la directiva de la empresa será difícil establecer una relación de confianza entre el ejecutivo "saliente" que ha incurrido en la actuación precedente y su "sucesor". Esto supondría que el "saliente" reconociera frente a su reemplazante la infracción previa de un deber y que este último asumiera voluntariamente una obligación de evitar el resultado lesivo que amenazara con concretarse en el futuro. Tales circunstancias difícilmente se darán en un caso de responsabilidad por el producto.

una consecuencia específica de la infracción al mandato jurídico. Como el tercero no ha infringido deber alguno en la actuación previa, nunca podrá afirmarse una relación entre la norma lesionada y el resultado acaecido (JASCH, "Übernahme", cit. nota n ${ }^{\circ} 71$, pp. 10 y s.).

${ }^{75}$ SCHUMANN, Heribert, Strafrechtliches Handlungsunrecht und das Prinzip der Selbstverantwortung der Anderen, Tübingen: Mohr Siebeck, 1986, p. 6. Sobre el principio de autorresponsabilidad como principio de imputación de conductas véase en detalle KÜHL, Strafrecht, cit. nota n ${ }^{\circ} 40, \S 4$, número marginal 83 y ss.

${ }^{76}$ En este sentido BOSCH, Organisationsverschulden, cit. nota n ${ }^{\circ}$ 14, p. 216.

${ }^{77}$ Véase infra nota ${ }^{\circ} 175$.

${ }^{78}$ JASCH, "Übernahme", cit. nota $n^{\circ}$ 71, p. 12; KÜHL, Kristian, "StGB § 13 Begehen durch Unterlassen", en: Lackner/Kühl Strafgesetzbuch Kommentar, $28^{a}$ edición, München: C. H. Beck, 2014, número marginal 9; JESCHECK; WEIGEND, Lehrbuch des Strafrechts, cit. nota n 32, p. 623.

${ }^{79}$ Cfr. JASCH, “Übernahme”, cit. nota n ${ }^{\circ} 71$, p. 12. 
CONTRERAS, Lautaro. "La posición de garante del fabricante en el Derecho penal alemán”.

\subsection{Resultado provisional.}

Las críticas formuladas al razonamiento del BGH sobre la injerencia muestran que el aspecto más problemático de esa posición de garante en los casos de responsabilidad por el producto consiste en la contrariedad a deber del actuar previo. Normalmente los productos son colocados en el mercado bona fide, esto es, partiendo del supuesto de que no representan ningún peligro para los consumidores ${ }^{80}$. Es usual que la peligrosidad del producto en el momento de su puesta en el mercado no sea cognoscible, ni siquiera cumpliendo cabalmente con los respectivos deberes de diseño, fabricación e instrucción ${ }^{81}$; en estos casos, el peligro (= riesgo de desarrollo) solo "se hace visible" de modo paulatino. Por eso, hasta el momento en que la peligrosidad se puede (o debe) advertir no cabe reprochar al fabricante ninguna conducta contraria a Derecho. Esto explica que la injerencia - concebida como un actuar previo con infracción de deber- permita en muy pocos casos fundar una posición de garante del fabricante.

Debido a las dificultades para afirmar la contrariedad a deber del hacer precedente en los casos de responsabilidad penal por el producto, la doctrina alemana ofrece otras propuestas de solución para fundar un deber de evitación de resultados. Estos planteamientos se vinculan con concepciones alternativas de la injerencia, con la vigilancia de fuentes de peligro, con los deberes desarrollados por la jurisprudencia civil y con la asunción de una función de protección. Todos ellos serán expuestos a continuación y sometidos a una revisión crítica. Es importante hacer presente que las objeciones que se formularán a estas propuestas de la doctrina alemana no pretenden cuestionar la existencia misma de una obligación jurídica de actuar del fabricante, sino poner de relieve la debilidad de las premisas conceptuales de tales propuestas o las inconsistencias entre los argumentos que estas esgrimen y sus propios presupuestos teóricos.

\section{El reemplazo del criterio de la contrariedad a deber en la injerencia por el de la especial peligrosidad.}

\subsection{Descripción.}

En la literatura científica relativa a la injerencia gana terreno una corriente según la cual el mandato de evitación de resultados puede tener su origen no solo en un actuar previo contrario a deber, sino también en uno especialmente riesgoso ${ }^{82}$. De acuerdo a esta teoría,

\footnotetext{
${ }^{80}$ Así BLOY, René, "Die strafrechtliche Produkthaftung auf dem Prüfstand der Dogmatik", en: BLOY, René et al (Editores), Gerechte Strafe und legitimes Strafrecht Festschrift für Manfred Maiwald zum 75. Geburtstag, Berlin: Duncker \& Humblot, 2010, p. 35-59, p. 44; HASSEMER, Produktverantwortung, cit. nota $\mathrm{n}^{\circ} 61$, p. 52.

${ }^{81}$ Sobre el significado y alcance de los deberes de diseño, fabricación e instrucción en una responsabilidad penal por el producto véase CONTRERAS, "La responsabilidad penal", cit. nota n 9, p. 276 y ss.

${ }^{82}$ En este sentido, véanse, entre otros, BOCK, Produktkriminalität, cit. nota $\mathrm{n}^{\circ} 13$, p. 137; DEUTSCHER; KÖRNER, "Die strafrechtliche Produktverantwortung”, cit. nota n 64, p. 301; FREUND, Georg, Strafrecht Allgemeiner Teil, $2^{a}$ edición, Berlin: Springer, 2009, § 6, número marginal 67 y ss.; FREUND, Georg, Erfolgsdelikt und Unterlassen, Köln: Heymann, 1992, pp. 180 y ss.; HERZBERG, Rolf Dietrich, Die Unterlassung im Strafrecht und das Garantenprinzip, Berlin: Walter de Gruyter, 1972, pp. 294 y ss.; KÖHLER, Strafrecht, cit. nota $n^{\circ}$ 20, p. 219 y s.; JAKOBS, Strafrecht, cit. nota ${ }^{\circ}$ 55, Sección 29, número marginal 39 y ss.; MEIER, Bern-Dieter, "Verbraucherschutz durch Strafrecht? Überlegungen zur
} 
Polít. crim. Vol. 12, № 23 (Julio 2017), Art. 1, pp. 1-55.

[http://www.politicacriminal.cl/Vol_12/n_23/Vol12N23A1.pdf]

el requisito de un comportamiento anterior contrario a Derecho restringiría demasiado el alcance de la responsabilidad por injerencia ${ }^{83}$, ya que -desde la perspectiva de una repartición justa de riesgos- puede resultar adecuado, en algunos casos en los que no se ha violado previamente norma de conducta alguna, que el curso lesivo sea imputado al "autor" y no a la víctima ${ }^{84}$. Se señala que la misma teoría que concibe la injerencia solo como un hacer precedente antijurídico reconoce hipótesis donde una actuación conforme a Derecho puede fundar tal posición de garante. Así, se acepta un mandato de evitación de resultados cuando la conducta previa está justificada por un estado de necesidad ${ }^{85}$, o cuando desaparecen los presupuestos de la justificación tratándose de una acción previa permitida con efecto permanente ${ }^{86}$. Estas excepciones demostrarían que la concordancia con el Derecho de la acción previa no conduce forzosamente a negar la existencia de un deber de evitación.

El presupuesto ineludible de la posición de garante por injerencia sería la "especial peligrosidad" del hacer precedente ${ }^{87}$. La conducta previa contraria a deber representaría el

strafrechtlichen Produkthaftung nach der Lederspray-Entscheidung des BGH”, NJW 1992, pp. 3193-3199, p. 3196; OTTO, "Die strafrechtliche Haftung", cit. nota n 53, pp. 308 y ss.; OTTO, Grundkurs, cit. nota n 73 , § 9, número marginal 81.

${ }^{83}$ En este sentido se pronuncian BEULKE; BACHMANN, "Die Lederspray-Entscheidung", cit. nota n 64, p. 740; JAKOBS, Günther, "Die Ingerenz in der Rechtsprechung des Bundesgerichtshofs", en: ROXIN, Claus; WIDMAIER, Gunther (Editores), 50 Jahre Bundesgerichtshof Festgabe aus der Wissenschaft Band IV Strafrecht Strafprozessrecht, München: C. H. Beck, 2000, pp. 29-49, p. 47; JAKOBS, Strafrecht, cit. nota ${ }^{\circ}$ 55, Sección 29, número marginal 29; OTTO, Grundkurs, cit. nota n 73, § 9, número marginal 81.

${ }^{84}$ Para Jakobs, una toma de postura en torno a si la contrariedad a deber es el único criterio para que el actuar precedente funde una posición de garante importa decidir, en aquellos casos donde la conducta previa está permitida pero representa un riesgo especial, a quién debe imputarse el curso lesivo: al autor, a la víctima que actúa a riesgo propio o a una tercera persona, siendo esta problemática de repartición de riesgos un asunto que también se presenta en los delitos comisivos (JAKOBS, Günther, "Teoría y praxis de la injerencia", $A D P C P$ 1999, Vol. LII, 1999, pp. 17-50, p. 44).

${ }^{85}$ Así ROXIN, Strafrecht, cit. nota ${ }^{\circ} 40, \S 32$, número marginal 186 y ss.; RUDOLPHI, Hans-Joachim, “\$ 13", en: RUDOLPHI, Hans-Joachim et al (Editores), SK StGB Systematischer Kommentar zum Strafgesetzbuch, Tomo I, $7^{\mathrm{a}}$ edición, en parte $8^{\mathrm{a}}$ edición, actualizado a octubre de 2005, Neuwied: Carl Heymanns, número marginal 40 a. Ejemplo: para evitar un accidente mortal, un automovilista se desvía velozmente hacia la calzada, lesionando gravemente a un peatón. El conductor huye del lugar, sin auxiliar a la víctima del atropello, quien muere posteriormente. En este tipo de casos Roxin sostiene que el automovilista tiene una obligación de evitar la muerte, porque ha interferido en el espacio de libertad de una persona que no tiene responsabilidad alguna en la situación de necesidad y que se ha visto forzada a sacrificar sus bienes (ROXIN, Strafrecht, cit. nota ${ }^{\circ} 40, \S 32$, número marginal 186).

${ }^{86}$ JESCHECK, Hans-Heinrich, "StGB $§ 13$ Begehen durch Unterlassen", en: JÄHNKE, Burkhard et al (Editores), Strafgesetzbuch Leipziger Kommentar Großkommentar, $11^{\mathrm{a}}$ edición, Berlin: Walter de Gruyter, 2003, número marginal 33; ROXIN, Strafrecht, cit. nota ${ }^{\circ} 40, \S 32$, número marginal 189; STREE; BOSCH, "StGB $\S 13$ ", cit. nota $n^{\circ} 32$, número marginal 36. Este sería el caso de un funcionario público que no revoca una autorización otorgada inicialmente conforme a Derecho, pero cuyos presupuestos decaen con posterioridad.

${ }^{87}$ Cfr. BOCK, Produktkriminalität, cit. nota n ${ }^{\circ} 13$, p. 135 ("riesgo especial"); JAKOBS, Strafrecht, cit. nota $\mathrm{n}^{\circ}$ 55, Sección 29, número marginal 42 ("riesgo especial”); OTTO, "Die strafrechtliche Haftung", cit. nota ${ }^{\circ}$ 53, p. 307 ("especial peligrosidad"). Junto a la expresión "riesgo especial" para aludir a la clase de peligro que debe crear el hacer precedente, se emplea también el término "conducta previa de riesgo incrementado" (KUHLEN, "Strafhaftung bei unterlassenem Rückruf”, cit. nota n 53, p. 568; MEIER, "Verbraucherschutz", cit. nota $n^{\circ} 82$, p. 3196). 
CONTRERAS, Lautaro. "La posición de garante del fabricante en el Derecho penal alemán”.

supuesto más evidente de especial peligrosidad de la acción previa, pero no sería el único ${ }^{88}$. Todo aquel que haya creado con su conducta riesgos especiales o calificados debe responder por las consecuencias evitables de su actuar, puesto que no se puede pretender sacar provecho del ejercicio de una actividad intensivamente peligrosa sin aportar las debidas "contraprestaciones"; quien no desee verse expuesto a tal responsabilidad, no debe entonces emprender la respectiva acción riesgosa ${ }^{89}$. La conducta previa fundará una posición de garante cuando cree peligros mayores que los que surgen de los comportamientos cotidianos ineludibles ${ }^{90}$; en cambio, si no se actúa de un modo más arriesgado de lo que resulta imprescindible en la vida diaria no existirá ningún deber de evitación ${ }^{91}$. De allí que sobre el sujeto que pasea tranquilamente por un parque no pese ningún deber de ayuda si su apariencia externa ocasiona que un perro - de gran tamaño- tire de tal modo la correa del dueño que haga caer a este violentamente al suelo, desencadenándose un curso causal que lo puede llevar a la muerte de no ser auxiliado ${ }^{92}$. En este caso, la conducta del paseante se movió dentro del ámbito de la acción socialmente habitual; el peligro de realización del resultado de muerte creado no sobrepasó aquel tipo de riesgo respecto del cual toda persona -también el dueño de un perro- puede adoptar precauciones por sí misma ${ }^{93}$. En cambio, si el ámbito de acción del sujeto se expande más allá de lo socialmente normal, asumiéndose frente a la potencial víctima un riesgo especial -aunque este revista el carácter de tolerado-, entonces el Derecho impondrá el deber de evitar la realización de ese riesgo ${ }^{94}$.

Uno de los representantes más destacados de esta concepción dogmática de la injerencia es Jakobs. Para este autor, las actuaciones previas ajustadas a Derecho también podrían fundar

\footnotetext{
${ }^{88}$ En este sentido JAKOBS, "Teoría y praxis", cit. nota n 84, p. 39; también FREUND, Strafrecht, cit. nota $\mathrm{n}^{\circ} 82, \S 6$, número marginal 69. La corriente doctrinal que defienden la "especial peligrosidad" del hacer previo como criterio decisivo para fundar la injerencia debe distinguirse de aquella según la cual es suficiente para configurar tal posición de garante con que se despliegue una conducta creadora de peligros, sin necesidad de que esta sea objeto de una calificación complementaria. En este último sentido se pronuncian ARZT, Gunther, "Zur Garantenstellung beim unechten Unterlassungsdelikt”, JA 1980, pp. 553-561, 647-654 y 712-717, p. 714; KAUFMANN, Arthur; HASSEMER, Winfried, "Der Praktische Fall/Strafrecht - Der überfallende Spaziergänger", JuS 1964, pp. 151-157, p. 153; MAIWALD, Manfred, "Grundlagenproblemen der Unterlassungsdelikte”, JuS 1981, pp. 473-483, p. 483. Según estos autores, debe renunciarse en el hacer precedente a la exigencia de la contrariedad a deber, bastando con que la creación del riesgo se pueda imputar al autor. Para ello, se basan en un argumento sistemático: tratándose de otras posiciones de garante (contrato, ley, estrecha comunidad de vida) no se exige la contrariedad a deber; sería contradictorio imponer tal requisito exclusivamente tratándose de la injerencia (ARZT, Gunther, "Zur Garantenstellung beim unechten Unterlassungsdelikt”, JA 1980, pp. 553-561, 647-654 y 712-717, p. 714). Además, como la infracción al deber tiene que ser advertida por el autor y la cognoscibilidad representa un proceso psíquico, surgirían enormes dificultades probatorias si se exigiera tal requisito, quedando en manos del propio sujeto afirmar o negar su concurrencia (cfr. WELP, Jürgen, Vorangegangenes Tun als Grundlage einer Handlungsäquivalenz der Unterlassung, Berlin: Duncker \& Humblot, 1968, p. 257). Crítica de la teoría de la injerencia entendida como mera conducta creadora de peligros se muestra WEI $\beta E R$, Kausalitäts- und Täterschaftsprobleme, cit. nota $n^{\circ} 24$, p. 42 y s.

${ }^{89}$ FREUND, Strafrecht, cit. nota ${ }^{\circ} 82, \S 6$, número marginal 69.

${ }^{90}$ Así JAKOBS, Strafrecht, cit. nota n ${ }^{\circ} 55$, Sección 29, número marginal 42. Argumentos similares se pueden encontrar en la fundamentación civil de la injerencia (véase BODEWIG, Der Rückruf, cit. nota n², p. 177).

${ }^{91}$ JAKOBS, "Teoría y praxis", cit. nota n 84 , p. 22.

${ }^{92}$ Ejemplo tomado de JAKOBS, “Teoría y praxis", cit. nota ${ }^{\circ} 84$, p. 22.

${ }^{93}$ Cfr. MEIER, "Verbraucherschutz", cit. nota n ${ }^{\circ} 82$, p. 3196.

${ }^{94}$ Cfr. JAKOBS, “Teoría y praxis", cit. nota ${ }^{\circ} 84$, p. 23 y s.
} 
Polít. crim. Vol. 12, № 23 (Julio 2017), Art. 1, pp. 1-55.

[http://www.politicacriminal.cl/Vol_12/n_23/Vol12N23A1.pdf]

una posición de garante, en la medida que hayan creado riesgos calificados, y siempre y cuando la persona puesta en peligro haya adoptado las medidas de autoprotección que le competen $^{95}$. Indicio de un peligro calificado sería la existencia de un sistema de responsabilidad por riesgo en la respectiva actividad o un seguro obligatorio jurídico-civil, tal como acontece en el tráfico aéreo y ferroviario, en la producción y uso de numerosas sustancias, en la experimentación con medicamentos o en materia de circulación vial ${ }^{96}$. La responsabilidad por riesgo o el seguro obligatorio darían cuenta que los peligros que genera la actividad no se valoran jurídicamente como peligros imprescindibles de la vida diaria; de ahí que de la respectiva actuación -aun cuando se mantenga dentro del umbral de lo tolerado- pueden surgir deberes de evitación de resultados. Así, el automovilista que atropella a un peatón por un defecto en su vehículo que no le resulta cognoscible estaría obligado a evitar la muerte mediante medidas de salvamento. Tal obligación de evitación no le sería exigible - en cambio - a aquel automovilista que conduce de modo correcto y atropella a un peatón ebrio que invade la calzada, provocando un accidente inevitable. En este último caso debe negarse una posición de garante del conductor, porque el peatón creó por sí mismo el peligro y, en consecuencia, no resulta justo imponer a aquel el deber de eliminarlo 97 .

Otro autor que renuncia en la injerencia al requisito de la contrariedad a deber es Freund. En su opinión, de la sola circunstancia de que un riesgo haya abandonado la esfera del "autor" como riesgo residual permitido, y haya alcanzado la esfera de la víctima, no se puede deducir que ese riesgo ya no le incumba al titular de la esfera original ${ }^{98}$. Y es que la permisión de riesgos está condicionada a ciertas razones de fondo específicas que, en caso de ya no estar presentes, obligan a adoptar soluciones necesariamente diferenciadas ${ }^{99}$. A modo de ejemplo: si un sujeto conduce ajustándose al cuidado debido y mata a un peatón que cruza de manera atolondrada la calle, causándose un resultado inmediato e inevitable, se afirma que el automovilista no es responsable, puesto que solo se ha realizado un riesgo creado por él de carácter tolerado. La razón de fondo de esa permisión se sustenta en la necesidad social de que exista un tráfico automotor en condiciones mínimamente fluidas. En este caso, la calificación del peligro creado como tolerado aparece como una solución adecuada al conflicto existente -en el instante anterior en que se produce el accidenteentre intereses en la libertad y en la conservación de bienes. Pero, a juicio de Freund, la solución debe ser distinta si el conductor diligente deja (solo) muy mal herido al peatón y huye del lugar, sin emprender ninguna medida de salvamento. En este caso, la no evitación del riesgo de muerte que proviene de la esfera del omitente no se puede apoyar en una correspondiente permisión de riesgos, puesto que la razón de fondo para autorizar la

\footnotetext{
95 JAKOBS, Strafrecht, cit. nota n 55, Sección 29, número marginal 42; véase también JAKOBS, “Teoría y praxis", cit. nota $\mathrm{n}^{\circ} 84$, p. 17 y ss. (especialmente pp. 34 y ss., 44 y ss., donde el autor profundiza la idea de que no es posible apreciar injerencia allí donde la víctima no adopta las medidas de seguridad que le incumben).

${ }^{96}$ Así expresamente JAKOBS, Strafrecht, cit. nota $n^{\circ}$ 55, Sección 29, número marginal 42; MEIER, "Verbrau-cherschutz", cit. nota n 82, p. 3196.

${ }^{97}$ Cfr. JAKOBS, “Teoría y praxis", cit. nota ${ }^{\circ} 84$, p. 36.

${ }^{98}$ FREUND, Erfolgsdelikt, cit. nota ${ }^{\circ}$ 82, p. 181; FREUND, Strafrecht, cit. nota $n^{\circ} 82, \S 6$, número marginal 68. Crítico respecto de la forma en que Freund fundamenta la injerencia SCHÜNEMANN, "Zum gegenwärtigen Stand", cit. nota $n^{\circ} 53$, p. 55 y s,

${ }_{99}$ FREUND, Erfolgsdelikt, cit. nota ${ }^{\circ} 82$, p. 181.
} 
CONTRERAS, Lautaro. "La posición de garante del fabricante en el Derecho penal alemán”.

conducción de vehículos - pese a los peligros que conlleva- no comprende el dejar morir a una víctima luego de una colisión inevitable ${ }^{100}$.

\subsection{Aplicación del criterio de la especial peligrosidad al caso del espray para cuero.}

Según los partidarios del criterio de la especial peligrosidad como elemento fundante de la injerencia, la responsabilidad por omisión impropia en el caso del espray para cuero podría basarse en esta posición de garante ${ }^{101}$. Así, para Jakobs la conducta del fabricante que pone en el mercado un producto que adolece de un defecto no cognoscible, poniendo en peligro la vida y salud de los consumidores, no es muy distinta a la del conductor que deja mal herido a un peatón a causa de una anomalía en su automóvil imposible de advertir ${ }^{102}$. En uno y otro caso estaríamos ante un hacer precedente que ha dado origen a un "riesgo especial", que obliga a emprender las respectivas medidas de salvamento. El carácter calificado del peligro creado a través de la introducción de productos en el mercado se deduce del régimen de responsabilidad por riesgo prevista en el parágrafo primero de la ley alemana de responsabilidad civil por productos $(\S 1 \text { ProdHaftG })^{103}$. De este régimen se desprendería que los peligros de la actividad de comercialización de productos no se valoran jurídicamente como riesgos vinculados con comportamientos cotidianos ineludibles, respecto de los cuales toda persona adopta precauciones por sí misma ${ }^{104}$. Por el contrario, este sistema de responsabilidad por riesgo impone cargas especiales al fabricante frente a la víctima del potencial daño, por lo que debería cumplir con el respectivo deber de salvamento.

En opinión de Freund, la posición de garante por injerencia del fabricante se funda en la idea de "autorización condicionada" de determinadas actividades calificadamente riesgosas. Para este autor, quien despliega tales actividades, previstas bajo la reserva expresa o tácita de evitar la realización de peligros que inicialmente no pudieron ser reconocidos, está obligado -si pretende realizarlas- a cumplir con tal deber de evitación ${ }^{105}$. Si el sujeto no quiere aceptar la reserva bajo la cual la actividad está permitida, entonces no debe desplegarla, puesto que no es posible pretender obtener ventajas de un particular ejercicio

\footnotetext{
${ }^{100}$ FREUND, Erfolgsdelikt, cit. nota n ${ }^{\circ} 82$, p. 182.

${ }^{101}$ Véase DEUTSCHER; KÖRNER, "Die strafrechtliche Produktverantwortung”, cit. nota n 64, p. 301; FREUND, Erfolgsdelikt, cit. nota $\mathrm{n}^{\circ}$ 82, p. 217 y ss.; FREUND, Strafrecht, cit. nota ${ }^{\circ}$ 82, § 6, número marginal 69 y ss.; JAKOBS, "Teoría y praxis", cit. nota $n^{\circ} 84$, p. 39; JAKOBS, Strafrecht, cit. nota $n^{\circ} 55$, Sección 29, número marginal 42; KUHLEN, "Strafhaftung bei unterlassenem Rückruf", cit. nota n 53, p. 569; LEGE, Micha Alexander, Strafbarkeitsbegründende Rechtspflichten zur Abwendung von Schäden durch gefährliche Produkte, insbesondere zum Rückruf rechtsgutsgefährdender Produkte, Tübingen: Köhler-Druck, 2000, p. 167; MEIER, "Verbraucherschutz", cit. nota n 82, p. 3196.

${ }^{102}$ Cfr. JAKOBS, “Teoría y praxis”, cit. nota n ${ }^{\circ} 84$, p. 39.

${ }^{103}$ JAKOBS, Strafrecht, cit. nota ${ }^{\circ}$ 55, Sección 29, número marginal 42. Como la primera frase del párrafo primero del $\S 1$ ProdHaftG solo pone como condición para la indemnización del daño la causación de la lesión a un bien jurídico a través de un defecto del producto, sin requerir adicionalmente una conducta defectuosa individual o la infracción a un deber de cuidado, se ha señalado en el Derecho alemán -aunque no sin controversia- que el régimen de responsabilidad previsto en la ProdHaftG sería uno estricto u objetivo (véase al respecto CONTRERAS, Normative Kriterien, cit. nota $\mathrm{n}^{\circ} 15$, p. 156).

${ }^{104}$ Cfr. JAKOBS, Strafrecht, cit. nota n ${ }^{\circ}$ 55, Sección 29, número marginal 42; MEIER, "Verbraucherschutz", cit. nota $\mathrm{n}^{\circ} 82$, p. 3196.

${ }^{105}$ Véase FREUND, Strafrecht, cit. nota $n^{\circ} 82, \S 6$, número marginal 69.
} 
Polít. crim. Vol. 12, № 23 (Julio 2017), Art. 1, pp. 1-55.

[http://www.politicacriminal.cl/Vol_12/n_23/Vol12N23A1.pdf]

de la libertad sin entregar las debidas "contraprestaciones""106. La idea de la autorización condicionada permitiría una solución convincente para sustentar la posición de garante en casos como el del espray para cuero: la introducción en el mercado de un bien de consumo solo se puede permitir bajo la reserva de que el fabricante adopte las respectivas medidas de evitación (incluyendo la advertencia y retirada) si reconoce, luego de la comercialización del bien, que este adolece de un defecto con potencial lesivo ${ }^{107}$.

En suma, para Jakobs y Freund la fabricación y la puesta en el mercado de bienes de consumo representan actividades de riesgo incrementado, que dan origen a una posición de garante por injerencia y ello con independencia de si la peligrosidad del producto -en caso de utilización racional- era cognoscible o no al momento de su comercialización.

\subsection{Apreciación crítica de la teoría de la especial peligrosidad de la conducta previa.}

Desde el punto de vista de la protección de los intereses del consumidor, las ventajas que ofrece la teoría de la especial peligrosidad de la conducta son evidentes. A diferencia de la doctrina mayoritaria relativa a la injerencia -que exige la contrariedad a deber de la comercialización previa del producto para fundar un deber de advertencia o retirada- esta teoría permite imponer un mandato de salvación incluso en aquellos casos en que la comercialización se mantuvo dentro del riesgo permitido. En efecto, aun cuando el producto se haya introducido en el mercado cumpliendo cabalmente los respectivos deberes de diseño, fabricación e instrucción, el productor estaría obligado por injerencia a una advertencia o retirada, si es que con posterioridad a la comercialización fuera cognoscible para él que el bien representa un peligro en caso de utilización racional.

El resultado final al que llega la teoría que renuncia a la contrariedad a deber para sustentar la injerencia es correcto: el fabricante está obligado a emprender medidas de evitación en favor del consumidor; sin embargo, su presupuesto conceptual (la idea de la "especial peligrosidad" del actuar previo) es débil. Porque en un continuo entre peligrosidad mínima y cercanía máxima al daño es casi imposible determinar un punto exacto en que el riesgo de la acción previa se eleve o califique ${ }^{108}$. Para enjuiciar una conducta como especialmente peligrosa o de riesgo incrementado son indispensables criterios objetivos, los que esta teoría no ha podido desarrollar. La creación de "peligros mayores que los existentes en los comportamientos cotidianos ineludibles" o el despliegue de una actividad "calificadamente peligrosa por existir autorizaciones condicionadas", resultan ser pautas extremadamente vagas para cualquier proceso de concretización de deberes jurídicos con relevancia penal ${ }^{109}$. Criterios semejantes difícilmente garantizan la aplicación igualitaria de las normas de sanción penal y el control de la corrección de las decisiones jurisdiccionales que se adopten en el campo de la omisión impropia; los peligros para la seguridad jurídica que surgen de

\footnotetext{
${ }^{106}$ Así FREUND, Strafrecht, cit. nota n 82, § 6, número marginal 69.

${ }^{107}$ FREUND, "StGB $§ 13$ ", cit. nota n 64, número marginal 123.

${ }^{108}$ HÖHFELD, Strafrechtliche Produktverantwortung, cit. nota n' 16, p. 134; HOYER, Andreas, "Die traditionelle Strafrechtsdogmatik vor neuen Herausforderungen: Probleme der strafrechtlichen Produkthaftung", GA 1996, pp. 160-178, p. 175.

${ }^{109}$ Cfr. BOSCH, Organisationsverschulden, cit. nota n ${ }^{\circ}$ 14, p. 209 y s., así como WEI $\beta E R$, Kausalitäts- und Täterschaftsprobleme, cit. nota $\mathrm{n}^{\circ} 24$, p. 49.
} 
CONTRERAS, Lautaro. "La posición de garante del fabricante en el Derecho penal alemán”.

una concepción semejante de la injerencia son evidentes. Además, la alusión que hace Jakobs al parágrafo primero de la ley alemana de responsabilidad civil por productos ( $\$ 1$ ProdHaftG), como demostración de que la actividad de fabricación de bienes de consumo impone cargas especiales al productor -las que incluirían mandatos de salvación-, es cuestionable, porque ese mismo precepto excluye cualquier responsabilidad extracontractual por riesgos de desarrollo. En efecto, de acuerdo al número 5 del párrafo segundo de dicha ley, el fabricante no debe responder por aquellos defectos que no pudieron ser advertidos al momento de la comercialización, aplicando los conocimientos científicos y técnicos existentes. Considerando el tenor de esta regla, es paradójico entonces invocar el $\S 1$ ProdHaftG para fundar la injerencia del fabricante en aquellos casos en que la peligrosidad del producto no era cognoscible al momento de su introducción en el mercado $^{110}$.

Otro aspecto problemático de la teoría de la especial peligrosidad de la conducta previa es que solo permite fundar un deber de evitación cuando el ejecutivo a cargo de la acción de advertencia o retirada fue quien introdujo el producto en el mercado. Incluso los autores que defienden esta concepción del hacer precedente reconocen -en atención al contenido altamente personal de los deberes de garante por injerencia- las dificultades que surgen cuando el actuar previo fue desplegado por un ejecutivo distinto de aquel que reconoce la peligrosidad del producto y que tiene en sus manos la advertencia o retirada ${ }^{111}$. Cualquier teoría que afirme la posición de garante del fabricante debe tener en cuenta no solo estos cambios en la integración en la directiva de la empresa, sino la circunstancia de que el proceso de elaboración de un producto se realiza siempre en división del trabajo, lo que conlleva que las personas competentes para su introducción en el mercado (esto es, las que incurrirán en el actuar previo) normalmente no coincidirán con aquellas que tienen a su cargo las medidas de evitación. En el marco de una organización empresarial, donde lo característico es que no todas las tareas sean competencia de todos, la injerencia constituye un criterio muy problemático para imputar responsabilidad omisiva.

Las dudas que arroja la teoría de la especial peligrosidad de la conducta previa nos obligan a seguir indagando otros argumentos - distintos a la injerencia- que permitan fundar los deberes de advertencia y retirada del fabricante.

\section{Las teorías que renuncian a la injerencia para fundar la posición de garante del fabricante.}

Las principales teorías que intentan fundar la obligación de actuar del fabricante al margen de la injerencia son la de la vigilancia de fuentes de peligro dentro del propio ámbito de dominio (a continuación infra 4.1.), la que deriva la obligación de actuar de los deberes desarrollados por la jurisprudencia civil (infra 4.2.) y la que la sustenta en la asunción de una función de protección (infra 4.3.).

\footnotetext{
${ }^{110}$ En un sentido similar véase BOSCH, Organisationsverschulden, cit. nota $n^{\circ} 14$, p. 210 .

111 Así OTTO, "Die strafrechtliche Haftung”, cit. nota n 53, p. 310 y s.
} 
Polít. crim. Vol. 12, № 23 (Julio 2017), Art. 1, pp. 1-55.

[http://www.politicacriminal.cl/Vol_12/n_23/Vol12N23A1.pdf]

\subsection{Responsabilidad del fabricante por fuentes de peligro dentro de su propio ámbito de dominio.}

\subsubsection{Descripción.}

Parte de la literatura científica funda la posición de garante del fabricante en la obligación de vigilar aquellas fuentes de peligro que se encuentran dentro del propio ámbito de dominio $^{112}$. En la dogmática de la omisión impropia alemana es ampliamente aceptada la idea de que todo aquel, en cuyo ámbito de competencia individual se encuentren elementos que puedan representar un peligro para bienes jurídicos de terceros, tiene el deber de mantener bajo control dicho ámbito abstractamente peligroso, y evitar que los riesgos potenciales se realicen y dañen intereses ajenos ${ }^{113}$. El fundamento de tal deber de evitación radica en que la comunidad espera que aquel que ejerce un poder de disposición (¡con facultades de exclusión de terceros!) sobre una determinada esfera de dominio o espacio delimitado, que permanece abierto a otros o desde el cual se puede afectar a otros, controle los peligros que surjan en esa esfera o espacio ${ }^{114}$. Los deberes de vigilancia de aquellas fuentes de peligro situadas dentro del propio ámbito de dominio se conocen también bajo la expresión "deberes de aseguramiento del tráfico"115.

${ }^{112}$ Cfr. al respecto BRAMMSEN, "Strafrechtliche Rückrufpflichten", cit. nota n 43, p. 113 y s.; BRAMMSEN, Joerg, "Unterlassungshaftung in formalen Organisationen”, en: AMELUNG, Knut (Editor), Individuelle Verantwortung und Beteiligungsverhältnisse bei Straftaten in bürokratischen Organisationen des Staates, der Wirtschaft und der Gesellschaft, Sinzheim: Pro Universitate, 2000, pp. 105-144, p. 117 y ss.; HILGENDORF, Strafrechtliche Produzentenhaftung, cit. nota ${ }^{\circ}$ 53, p. 141; HÖHFELD, Strafrechtliche Produktverantwortung, cit. nota $\mathrm{n}^{\circ}$ 16, p. 150; RANSIEK, Andreas, Unternehmensstrafrecht Strafrecht Verfassungsrecht Regelungsalternativen, Heidelberg: Müller, 1996, p. 39; RANSIEK, Andreas, "Zur deliktischen Eigenhaftung des GmbH-Geschäftsführers aus strafrechtlicher Sicht”, ZGR 1992, pp. 203-231, p. 216; WEI $\beta E R$, Kausalitäts- und Täterschaftsprobleme, cit. nota n ${ }^{\circ} 24$, p. 59 y s., 64.

${ }^{113}$ Cfr. KÜHL, Strafrecht, cit. nota $\mathrm{n}^{\circ} 40, \S 18$, número marginal 106 y ss.; OTTO, "Die strafrechtliche Haftung”, cit. nota $n^{\circ}$ 53, p. 296; ROXIN, Strafrecht, cit. nota $n^{\circ} 40$, $§ 32$, número marginal 108 y ss.; WOHLERS, Wolfgang; GAEDE, Karsten, "StGB § 13 Begehen durch Unterlassen”, en: KINDHÄUSER, Urs et al (Editores), Nomos Kommentar Strafgesetzbuch, Tomo 1, 4 a edición, Baden-Baden: Nomos, 2013, número marginal 46.

${ }^{114}$ En este sentido JESCHECK; WEIGEND, Lehrbuch des Strafrechts, cit. nota ${ }^{\circ}$ 32, p. 627; cfr. también BOSCH, Organisationsverschulden, cit. nota $\mathrm{n}^{\circ} 14$, p. 189.

${ }^{115}$ Véase, por ejemplo, MURMANN, Uwe, Grundkurs Strafrecht, 2a edición, München: C. H. Beck, 2013, § 29, número marginal 59; WOHLERS; GAEDE, "StGB § 13", cit. nota n 113, número marginal 46. El sentido de la expresión "deberes de aseguramiento del tráfico" en el Derecho penal es distinto al alcance que tiene el término en el Derecho civil. Los deberes de vigilancia de aquellas fuentes de peligro situadas dentro del propio ámbito de dominio se conocen en el Derecho civil también como "deberes de aseguramiento del tráfico", pero este concepto tiene un sentido más amplio que su correlato penal, puesto que también abarca casos en que el acaecimiento del daño no está sujeto al control directo de la fuente de peligro por parte del obligado (véase BOSCH, Organisationsverschulden, cit. nota $\mathrm{n}^{\circ} 14$, p. 188; MAYER, Strafrechtliche Produktverantwortung, cit. nota $\mathrm{n}^{\circ} 14$, p. 254 y s. con abundantes notas). En efecto, a diferencia de lo que ocurre con los deberes penales de vigilancia de fuentes de peligro, que -según la doctrina mayoritariaimportan la obligación de asegurar un ámbito de riesgo dominable fácticamente (por todos véase SCHÜNEMANN, Bernd, "Strafrechtsdogmatische und kriminalpolitische Grundfragen der Unternehmenskriminalität”, wistra 1982, pp. 41-50, p. 44), los deberes de aseguramiento del tráfico del Derecho civil se conciben como obligaciones de respetar los intereses ajenos. Efectivamente, en el Derecho civil alemán se habla de "deberes de aseguramiento del tráfico" en alusión a aquellas normas de conducta que obligan a respetar los intereses de los demás, y cuya infracción es uno de los requisitos para aplicar la norma de sanción del $\S 823$, párrafo primero, del Código Civil. La expresión "deberes de aseguramiento del tráfico" 
CONTRERAS, Lautaro. "La posición de garante del fabricante en el Derecho penal alemán”.

Tratándose de esta posición de garante resulta indiferente si la causación del peligro tiene su origen en una conducta contraria a deber o, por el contrario, se produce en el contexto de una actividad tolerada. ${ }^{116} \mathrm{El}$ deber de aseguramiento solo se funda en una relación entre el garante y una determinada fuente de peligro. Los casos de responsabilidad especial de actuar en virtud de esta posición de garante son variados. Así, por ejemplo, el dueño de un perro agresivo debe vigilarlo o controlarlo por medio de una reja, una correa, un bozal, etc. para que no lesione la salud o incluso la vida de terceros ${ }^{117}$. Quien tiene a su cargo un vehículo está obligado a mantenerlo siempre en un estado óptimo de seguridad ${ }^{118}$. Del mismo modo, el responsable de una obra de construcción está obligado a adoptar las medidas necesarias para evitar que objetos peligrosos caigan y dañen a terceros, se produzca un incendio debido al almacenamiento de materiales inflamables o transeúntes caigan en alguna excavación ${ }^{119}$. En todos estos casos el elemento fundante del deber de garante es el dominio efectivo sobre una fuente de peligro que se encuentra dentro de un ámbito espacial de influencia; de ese dominio se deriva -precisamente- la obligación de controlar el peligro $^{120}$.

tuvo su origen en el Derecho civil a propósito de varios casos en que la parte demandante había sufrido daños en el contexto del uso de vías públicas, calles y plazas; de allí que se comenzara hablando de "deberes de aseguramiento del tráfico". Con el tiempo el concepto se comenzó a aplicar para aludir a deberes de control de otra clase de fuentes de peligro, como animales o productos defectuosos (sobre el origen y contenido del concepto "deber de aseguramiento del tráfico" en el Derecho civil alemán véase WAGNER, Gerhard, "BGB § 823 Schadenersatzpflicht", en: SÄCKER, Franz Jürgen et al [Editores], Münchener Kommentar zum Bürgerlichen Gesetzbuch, Tomo 5, 6 $6^{\mathrm{a}}$ edición, München: C. H. Beck, 2013, número marginal 297). Es necesario destacar que para el Derecho penal los deberes de aseguramiento del tráfico civil no solo revisten importancia en el contexto de la dogmática de la omisión impropia, sino también para determinar la medida de cuidado en los delitos culposos (expresamente en este sentido BEULKE; BACHMANN, "Die LedersprayEntscheidung", cit. nota ${ }^{\circ}$ 64, p. 740).

${ }^{116}$ Véase, en este sentido, BEULKE; BACHMANN, "Die Lederspray-Entscheidung", cit. nota n 64, p. 740; DEUTSCHER; KÖRNER, "Die strafrechtliche Produktverantwortung", cit. nota n 64, p. 300. En favor de una equiparación entre los deberes de vigilancia de cosas peligrosas que se hallan en el propio ámbito de dominio y los deberes de garante por hacer precedente JAKOBS, Strafrecht, cit. nota $\mathrm{n}^{\circ} 55$, Sección 29 , número marginal 31, para quien el actuar previo "es un acto de organización que da lugar a un peligro que obliga al aseguramiento al titular del ámbito de organización que se ha convertido en peligroso". Crítico respecto de esta homologación se manifiesta Otto. Para él, los deberes de aseguramiento del tráfico no tienen que ver -como si ocurre con los deberes fundados en la injerencia- con la obligación de omitir ciertas actuaciones previas peligrosas, sino con las expectativas de seguridad de la comunidad, que confía en que determinados objetos o lugares peligrosos se mantendrán bajo vigilancia, no haciéndose necesario prestar atención y cuidado a los mismos. Una equiparación de ambos tipos de deberes impediría apreciar una diferencia esencial entre ambos: la posibilidad de transferir la obligación de evitar el resultado, la que solo existiría en los deberes de vigilancia de objetos o lugares peligrosos, en la medida que la persona que asume el cumplimiento del deber comience a ejercer fácticamente un nuevo dominio sobre el objeto o lugar (ver OTTO, "Die strafrechtliche Haftung", cit. nota n 53, p. 294 y ss.).

${ }^{117}$ En este sentido ROXIN, Strafrecht, cit. nota $\mathrm{n}^{\circ} 40, \S 32$, número marginal 114, con citas a abundante jurisprudencia alemana.

${ }_{118}$ Así FRISTER, Helmut, Derecho penal Parte General, traducción de la $4^{\mathrm{a}}$ edición alemana, Buenos Aires: Hammurabi, 2011, Capítulo 22, número marginal 25; STREE; BOSCH, "StGB § 13", cit. nota n 32, número marginal 43.

${ }^{119}$ Cfr. WOHLERS; GAEDE, "StGB § 13”, cit. nota n 113 , número marginal 47.

${ }^{120}$ Cfr. OTTO, "Die strafrechtliche Haftung”, cit. nota n 53, p. 297; SCHMUCKER, Die „Dogmatik“, cit. nota $\mathrm{n}^{\circ} 13$, p. 145. 
Polít. crim. Vol. 12, № 23 (Julio 2017), Art. 1, pp. 1-55.

[http://www.politicacriminal.cl/Vol_12/n_23/Vol12N23A1.pdf]

Una empresa también puede constituir una fuente de peligro, y no solo debido a las emisiones contaminantes para el medio ambiente que puedan provenir de sus instalaciones, sino también a causa de los productos defectuosos que se fabriquen en su seno ${ }^{121}$. Sin embargo, la exigencia del dominio efectivo sobre la fuente de peligro -característica propia del deber de aseguramiento del tráfico, según la doctrina mayoritaria- limita la responsabilidad por omisión al ámbito espacial u organizativo que esté bajo el control directo de los ejecutivos competentes ${ }^{122}$. De allí que pueda imponerse la obligación de no comercializar una partida de producto defectuoso en la medida que esta todavía permanezca en las bodegas de la empresa, a la espera de ser distribuida, haciéndose de pronto evidente su peligrosidad; en este caso los bienes todavía se encuentran bajo la esfera de dominio de los sujetos competentes. Pero si la partida defectuosa ya fue introducida en el mercado, encontrándose en poder de minoristas o incluso en manos de consumidores finales, y solo entonces se reconoce su carácter peligroso, no podrá hablarse de una obligación de advertencia o retirada basada en un deber de aseguramiento del tráfico, puesto que el producto habrá abandonado ya el ámbito de dominio del fabricante ${ }^{123}$. En este caso, de no aceptarse una teoría de la injerencia basada en la especial peligrosidad de la conducta previa, se afirma en Alemania que el fabricante inactivo solo podría ser castigado por la vía del $\S 323 \mathrm{c} \mathrm{StGB}^{124}$.

Un grupo de autores ha intentado superar las dificultades para fundar el deber de advertencia o retirada del fabricante a través de la posición de garante de vigilancia de cosas peligrosas, revisando el concepto de dominio sobre la fuente de peligro ${ }^{125}$. Según ellos, esta idea de dominio no debería concebirse exclusivamente como una relación de custodia que permite al garante acceder corporalmente en todo momento a la $\operatorname{cosa}^{126}$, ya

${ }^{121}$ Así OTTO, "Die strafrechtliche Haftung", cit. nota n 53, p. 297.

${ }^{122}$ Así MAYER, Strafrechtliche Produktverantwortung, cit. nota ${ }^{\circ}$ 14, p. 256; OTTO, "Die strafrechtliche Haftung", cit. nota n ${ }^{\circ}$ 53, p. 297.

${ }^{123}$ Véase BOSCH, Organisationsverschulden, cit. nota $\mathrm{n}^{\circ} 14$, p. 189; BUSCH, Ralf, Unternehmen und Umweltstrafrecht, Osnabrück: Universitätsverlag Rasch, 1997, p. 256; GOLL, Eberhard; WINKELBAUER, Wolfgang, "§ 47. Materielle Voraussetzungen der strafrechtlichen Verantwortung für fehlerhafte Produkte", en: GRAF V. WESTPHALEN, Friedrich (Editor), Produkthaftungshandbuch, Tomo 1, $2^{\mathrm{a}}$ edición, München: C. H. Beck, 1997, número marginal 11 y s.; OTTO, "Die strafrechtliche Haftung", cit. nota $\mathrm{n}^{\circ}$ 53, p. 297; SCHMUCKER, Die „Dogmatik“, cit. nota no 13, p. 145; SCHÜNEMMAN, Bernd, Unternehmenskriminalität und Strafrecht, Köln: Carl Heymanns, 1979, p. 99.

${ }^{124}$ Así DEUTSCHER; KÖRNER, "Die strafrechtliche Produktverantwortung", cit. nota $n^{\circ}$ 64, p. 300. El $\S 323 \mathrm{c}$ StGB (omisión del deber de socorro) castiga a quien en caso de accidente o de peligro público o necesidad no preste ayuda, a pesar de que esta sea necesaria y exigible de acuerdo a las circunstancias del caso, en especial cuando sea posible prestarla sin considerable peligro propio y sin lesión de otros deberes importantes. En detalle sobre la posible aplicación del $\S 323 \mathrm{c}$ StGB a los casos de responsabilidad por el producto BOCK, Produktkrimi-nalität, cit. nota ${ }^{\circ} 13$, pp. 54 y ss.

${ }^{125}$ Véase BRAMMSEN, "Strafrechtliche Rückrufpflichten", cit. nota ${ }^{\circ} 43$, p. 113 y s.; BRAMMSEN, "Unterlassungshaftung", cit. nota ${ }^{\circ}$ 112, p. 117 y ss.; HILGENDORF, Strafrechtliche Produzentenhaftung, cit. nota $\mathrm{n}^{\circ}$ 53, p. 141; RANSIEK, Unternehmensstrafrecht, cit. nota ${ }^{\circ} 112$, p. 39; RANSIEK, "Zur deliktischen Eigenhaftung”, cit. nota ${ }^{\circ} 112$, p. 216; WEI $\beta E R$, Kausalitäts- und Täterschaftsprobleme, cit. nota $\mathrm{n}^{\circ} 24$, p. 59 s., 64.

${ }^{126} \mathrm{La}$ idea de dominio sobre la fuente de peligro concebida como relación de custodia puede encontrarse en SCHÜNEMANN, "Strafrechtsdogmatische und kriminalpolitische Grundfragen", cit. nota $\mathrm{n}^{\circ} 115$, p. 44: "Este dominio presupone, de un modo similar a lo que ocurre con el concepto de custodia en el $\S 242 \mathrm{StGB}$ [tipo penal de hurto], un ámbito privativo de influencia espacial, dentro del cual se encuentra el objeto peligroso; con la salida desde ese ámbito de influencia desaparece el dominio sobre la cosa...”. Véase también 
CONTRERAS, Lautaro. "La posición de garante del fabricante en el Derecho penal alemán”.

que esto impediría dar una solución satisfactoria al conflicto entre intereses en la libertad y en la conservación de bienes jurídicos. El dominio no debe entenderse solo en un sentido físico-real (fáctico), sino también -y especialmente- en una acepción normativo-social.

Uno de los autores que se ha esforzado por revisar el concepto de dominio sobre la fuente de peligro ha sido Weißer. En su trabajo doctoral destaca que aplicar el tipo de omisión propia del § 323c StGB al fabricante que no retira un producto del mercado -negando así que pese sobre él una posición de garante por dominio sobre la fuente de peligro-, implicaría hacer responsable al fabricante de la misma manera que a un tercero ajeno al proceso productivo, lo que no resulta razonable ${ }^{127}$. Imponer a ese tercero (únicamente) un deber general de solidaridad en favor del consumidor es correcto, puesto que aquel no tiene ninguna responsabilidad especial por la fuente de peligro "producto". Completamente distinta es la situación del fabricante, quien se vincula con el bien de consumo de una manera sumamente estrecha: es él quien decide libremente qué productos introducirá en el mercado, el que desarrolla las estrategias de publicidad que le resulten convenientes, el que procura vender la mayor cantidad posible de unidades y el que obtiene las utilidades de la comercialización $^{128}$. Esa especial relación con el producto impide castigar al fabricante que no emprende medidas de salvamento- solo por la vía del § 323c StGB, tal como se haría con un tercero. El propio Tribunal Supremo Federal alemán reconoció en la sentencia del caso del espray para cuero las importantes diferencias existentes entre la posición que ocupa el fabricante frente al consumidor de aquella que ocupa un tercero ajeno al proceso productivo $^{129}$. Weißer reconoce que, una vez que el producto ha sido puesto en el mercado, ya no puede hablarse de que el fabricante ejerza un dominio fáctico sobre el objeto; sin embargo, a partir de ese momento, el fabricante cuenta con importantes facultades para intervenir y ejercer un control sobre todos los problemas vinculados con el producto ${ }^{130}$. Estas facultades se sustentan - primeramente-, en la posición aventajada que el fabricante tiene respecto de la información sobre los factores de riesgo del producto ${ }^{131}$. Ciertamente,

SCHUMANN, Strafrechtli-ches Handlungsunrecht, cit. nota ${ }^{\circ} 75$, p. 118, que justifica el alcance limitado de la posición de garante de dominio sobre la fuente de peligro en razón de la custodia espacial que posee el titular.

${ }^{127}$ Cfr. WEIßER, Kausalitäts- und Täterschaftsprobleme, cit. nota $\mathrm{n}^{\circ} 24$, p. 59 con críticas a Schünemann por sostener este que la conducta del fabricante que omite llevar a cabo una acción de retirada solo puede castigarse por la vía del $\S 323$ c StGB. En España Juanatey destaca que el fabricante ocupa una posición "ontológicamente" distinta a la de un tercero, de lo que se derivaría una posición "deontológicamente diversa" (JUANATEY, Carmen, "Responsabilidad penal omisiva del fabricante o productor por los daños a la salud derivados de productos introducidos correctamente en el mercado", ADPCP, VOL. LVII, 2004, pp. 53-75, p. 61).

${ }^{128}$ Así WEIßER, Kausalitäts- und Täterschaftsprobleme, cit. nota n 24, p. 59.

${ }^{129}$ Señala el BGH sobre este punto: "El fabricante y la organización de distribución poseen la visión de conjunto más completa, puesto que son ellos los que reúnen las comunicaciones relativas a los daños. Una acción de retirada proveniente de ellos tiene mayores posibilidades de tener efectos en comparación a la intervención de terceros, puesto que debería suponerse que cuentan con los conocimientos técnicos necesarios para valorar el carácter defectuoso del producto, calcular el grado del peligro y elegir correctamente las medidas necesarias para su eliminación. También aquí se distingue la posición que ocupa frente al consumidor el fabricante responsable, o su organización de distribución, en comparación con un tercero ajeno" (BGHSt, 37, 106, 121).

${ }^{130}$ Cfr. WEI $\beta E R$, Kausalitäts- und Täterschaftsprobleme, cit. nota $\mathrm{n}^{\circ} 24$, p. 59. Con una argumentación similar JUANATEY, "Responsabilidad penal omisiva", cit. nota n 127, p.71.

${ }^{131}$ Ver WEI $\beta$ ER, Kausalitäts- und Täterschaftsprobleme, cit. nota ${ }^{\circ} 24$, p. 59. 
Polít. crim. Vol. 12, № 23 (Julio 2017), Art. 1, pp. 1-55.

es el fabricante, y solo él, quien puede tomar conocimiento de los riesgos de desarrollo, ya sea a través de la vigilancia activa del bien, ya sea a través de una investigación exhaustiva de los incidentes que hayan afectado con anterioridad a los usuarios ${ }^{132}$. Además, el fabricante es el único que puede analizar y valorar adecuadamente tales riesgos, alertando en caso necesario a los consumidores para que estos reciban así un producto exento de falla, acudan a un servicio técnico gratuito o adopten las respectivas medidas de autoprotección. Las facultades del fabricante para intervenir en los problemas vinculados con el producto se sustentan, además, en el poder que este tiene para ejecutar de un modo centralizado una acción de advertencia o retirada que sea tomada en serio por los consumidores ${ }^{133}$. Como el fabricante ocupa una posición aventajada respecto de la información concerniente al riesgo del producto y como está a su alcance llevar a cabo una acción efectiva de advertencia o retirada, se puede decir que aquel ejerce un dominio sobre el producto peligroso, aun después de su comercialización, por lo que debe emprender las medidas de salvamento necesarias y exigibles para no responder por un delito de omisión impropia ${ }^{134}$.

En el seno de la corriente doctrinaria que ha intentado superar el concepto físico-real de dominio se señala, además, que aquel ignora la complejidad de la interacción social en la que se basan la posiciones de deber de los garantes de vigilancia, por lo que, para fundarlas, hay que recurrir no solo a las relaciones de dominio puramente fácticas, sino también a las relaciones jurídicas de influencia y disposición sobre el objeto peligroso ${ }^{135}$. Solo de esta manera se garantiza la debida consideración del conjunto de vínculos sociales, cuyo examen permite advertir que ciertos sujetos tienen responsabilidades especiales, reconocidas como tales por el conjunto de la comunidad ${ }^{136}$. De quien obtiene provecho de la explotación de una fuente de peligro y además posee el monopolio para ejercer influencia sobre dicha fuente, se puede esperar legítimamente que se haga responsable por los daños causados por el peligro $^{137}$.

Como se puede apreciar de lo expuesto, el deber de advertencia o retirada de un producto defectuoso, cuya peligrosidad solo resultó cognoscible después de su introducción en el mercado, también ha intentado fundarse a través de los llamados "deberes de aseguramiento del tráfico". Para ello, la doctrina ha debido ampliar el concepto de "dominio" sobre la fuente de peligro, entendiendo este no solo en un sentido físico-real, sino también normativo-social. En la medida que el sujeto esté en condiciones de ejercer influencia sobre el riesgo proveniente del objeto peligroso, deberá afirmarse una posición

\footnotetext{
${ }^{132}$ Sobre el significado de los deberes de vigilancia activa y pasiva véase nota $n^{\circ} 193$.

${ }^{133}$ En este sentido WEI $\beta E R$, Kausalitäts- und Täterschaftsprobleme, cit. nota $\mathrm{n}^{\circ} 24$, p. 60.

${ }^{134}$ Dado el caso, el poder para realizar una acción de retirada eficaz también lo tendría una empresa distribuidora, por lo que los órganos competentes de la misma también deberían evitar los resultados lesivos causados por un producto defectuoso (WEI $\beta E R$, Kausalitäts- und Täterschaftsprobleme, cit. nota ${ }^{\circ} 24$, p. 59 y s.).

${ }^{135}$ BRAMMSEN, "Strafrechtliche Rückrufpflichten”, cit. nota n 43, p. 113 y s.; BRAMMSEN, "Unterlassungshaftung", cit. nota $\mathrm{n}^{\circ} 112$, p. 117 y ss.

${ }^{136}$ Cfr. BRAMMSEN, "Strafrechtliche Rückrufpflichten”, cit. nota n 43, p. 113.

${ }^{137}$ Así, HILGENDORF, Strafrechtliche Produzentenhaftung, cit. nota $\mathrm{n}^{\circ}$ 53, p. 141, recordando la idea siempre presente en los deberes de aseguramiento- de que aquel que está facultado para tomar decisiones dentro de un determinado ámbito de competencia tiene que velar, como reverso del reconocimiento de esa facultad, por que de ese ámbito no surjan peligros para terceros.
} 
CONTRERAS, Lautaro. "La posición de garante del fabricante en el Derecho penal alemán”.

de garante, y ello con independencia de que el objeto haya salido de su ámbito de control fáctico.

4.1.2. Aplicación al caso del espray para cuero de la idea de la responsabilidad por las fuentes de peligro situadas dentro del propio ámbito de dominio.

Conforme a la corriente doctrinaria que concibe el dominio sobre las fuentes de peligro de un modo normativizado, sobre los acusados en el caso del espray para cuero pesaba una posición de garante que les obligaba a retirar el producto. Sin perjuicio de que este ya había abandonado el ámbito espacial de la empresa, existían posibilidades de intervenir en su proceso de comercialización, por lo que debían adoptarse las medidas de salvamento que la situación exigía. Para afirmar la obligación de actuar de los acusados era irrelevante que la peligrosidad del producto no haya sido cognoscible en el momento de su introducción en el mercado, porque la posición de garante derivada de la responsabilidad por una fuente de peligro situada en el propio ámbito de competencia no reposa en una determinada conducta (previa), sino únicamente en la relación que se tiene con el objeto o instalación peligrosa ${ }^{138}$.

Aunque en el caso del espray para cuero el BGH haya fundado el deber de retirada de los acusados en la injerencia, el propio tribunal destacó la importancia de la posibilidad de ejercer influencia fáctica en el producto para reconocer un deber jurídico de evitación de resultados. Al respecto señaló:

"La otra objeción de que la empresa no posee ningún poder jurídico para ejercer influencia sobre el destino de los productos que ya llegaron al mercado no es procedente, porque para reconocer un deber jurídico de evitación de daño solo son importantes las posibilidades reales de la influencia y tales posibilidades justamente existen en forma de retirada (...)."139

4.1.3. Apreciación crítica de la idea de la responsabilidad por las fuentes de peligro situadas dentro del propio ámbito de dominio.

A diferencia de la concepción tradicional del hacer precedente, la posición de garante derivada de las fuentes de peligro situadas en el propio ámbito de dominio no requiere ninguna contrariedad a deber de la conducta para fundar un mandato de evitación. En consecuencia, aunque el carácter defectuoso del producto no sea cognoscible para el fabricante al momento de su comercialización, ${ }^{140}$ este está obligado a la respectiva advertencia o retirada si con posterioridad reconoce un riesgo de desarrollo. Esta forma de sustentar la posición de garante del fabricante es claramente favorable para los intereses del consumidor. Pero además, y a diferencia de lo que ocurre con la injerencia, -ya sea que esta se entienda como hacer previo contrario a deber o como conducta precedente generadora de un riesgo especial o calificado-, el deber de salvación basado en las fuentes de peligro situadas en el propio ámbito de dominio obliga siempre a aquel o a aquellos ejecutivos que ejercen tal dominio, con independencia de que hayan sido ellos quienes pusieron el

\footnotetext{
${ }^{138}$ En este sentido HILGENDORF, Strafrechtliche Produzentenhaftung, cit. nota ${ }^{\circ}$ 53, p. 141; WEI $\beta E R$, Kausalitäts- und Täterschaftsprobleme, cit. nota $\mathrm{n}^{\circ} 24$, p. 60.

${ }^{139}$ Véase $B G H S t, 37,106,121$ (el destacado es nuestro).

${ }^{140}$ Lo que -como ya se ha dicho- no es poco frecuente en los casos de responsabilidad por el producto.
} 
Polít. crim. Vol. 12, № 23 (Julio 2017), Art. 1, pp. 1-55.

[http://www.politicacriminal.cl/Vol_12/n_23/Vol12N23A1.pdf]

producto defectuoso en el mercado. Las dificultades, relativas a la transferibilidad del mandato de salvación al ejecutivo "sucesor" de aquel que comercializó el bien de consumo, no se presentan tratándose de esta posición de garante, porque esta no se basa en una conducta personal anterior que da lugar a deberes personalísimo, sino en la relación actual con el objeto peligroso.

Sin perjuicio de que los autores que intentan fundar la posición de garante del fabricante a través de los deberes de aseguramiento del tráfico llegan a la solución correcta (sobre el fabricante pesa una obligación jurídica de actuar), los argumentos que esgrimen para ello no están exentos de reparos. En efecto, uno podría aceptar una normativización del concepto de dominio en el ámbito empresarial y entender que este no solo comprende un control fáctico sobre la cosa, sino también un control de carácter institucional. En consecuencia, se podría ver un caso de ejercicio de dominio cuando una empresa, que tiene a su cargo la distribución del producto, está subordinada -desde el punto de vista organizativo- a la empresa fabricante, lo que permite a uno de los ejecutivos de esta directamente, o mediante alguna forma de dominio institucionalizado, ejercer influencia sobre el producto o sobre otro ejecutivo de la empresa distribuidora, consiguiendo retirar el bien de consumo del mercado ${ }^{141}$. Pero ya no se puede hablar de una relación de dominio si el producto está en las bodegas de una empresa distribuidora independiente, o en el escaparate de un pequeño comercio sin ninguna relación de subordinación con el fabricante o -más aún-, en la alacena del consumidor que acaba de comprar el bien ${ }^{142}$. En estos casos no se puede ejercer influencia fáctica o jurídica alguna sobre el objeto peligroso, por lo que la idea de dominio no es idónea para fundar un mandato de evitación de resultados lesivos. Es cierto que el fabricante puede informar al consumidor acerca de los peligros del bien, permitiéndole adoptar precauciones especiales; sin embargo, ejercer influencia en la decisión que vaya a tomar una persona autorresponsable no puede equipararse de ningún modo a ejercer el control sobre un objeto peligroso ${ }^{143}$. No se puede obviar que el elemento constitutivo de cualquier deber de aseguramiento del tráfico es el dominio sobre la fuente de peligro, el que tiene que estar dotado de un mínimo de base real.

Pero además, los intentos de Weißer y otros autores de ampliar el concepto de dominio sobre la fuente de peligro, entendiendo que este también se configura cuando existen posibilidades por parte de un ejecutivo de intervenir en el proceso productivo, o de ejercer influencia sobre el producto, resultan cuestionables, porque sustentan el deber jurídico de advertencia o retirada en un mero dato de la naturaleza. No existe ninguna razón para derivar de la circunstancia fáctica de estar en condiciones de advertir de los riesgos del producto al consumidor, o de retirar el bien del mercado, un mandato de salvamento ${ }^{144}$. Quien tiene en sus manos la posibilidad de evitar un resultado, no tiene forzosamente el

\footnotetext{
${ }^{141}$ En este sentido BUSCH, Unternehmen, cit. nota ${ }^{\circ}$ 123, p. 533; OTTO, "Die strafrechtliche Haftung", cit. nota $\mathrm{n}^{\circ} 53$, p. 298.

${ }^{142}$ Cfr. OTTO, "Die strafrechtliche Haftung", cit. nota n 53, p. 298.

${ }^{143}$ Cfr. ROXIN, Strafrecht, cit. nota ${ }^{\circ} 40, \S 32$, número marginal 209, para quien los mandatos de evitación de resultados que el Derecho puede imponer legítimamente al fabricante no se basan en la vigilancia y control sobre una fuente de peligro sino - como se verá en infra 4.3.- en la asunción de una función de protección.

${ }^{144}$ Crítico contra el método de acudir a perspectivas fácticas para dar solución a problemas normativos en el ámbito de la omisión FREUND, Erfolgsdelikt, cit. nota nº 82, p. 137 y s.
} 
CONTRERAS, Lautaro. "La posición de garante del fabricante en el Derecho penal alemán".

deber jurídico de hacerlo ${ }^{145}$. La evitabilidad es un argumento demasiado inespecífico para fundar una posición de garante, puesto que toda conducta punible de un delito que no se construya sobre la base de la mera actividad (también aquella conducta que infringe una prohibición) exige una capacidad de evitación del acaecimiento del resultado ${ }^{146}$. Esto se suele destacar por la teoría de la imputación objetiva, al afirmarse que un resultado solo se puede atribuir a la conducta del sujeto cuando, de haberse mantenido este dentro del riesgo tolerado, el resultado se hubiera evitado con una probabilidad rayana en la certeza ${ }^{147}$.

Debido a las objeciones anteriores no resulta sostenible fundar la posición de garante del fabricante mediante el criterio del dominio sobre la fuente de peligro.

\subsection{Posición de garante del fabricante basada en los deberes desarrollados por la jurisprudencia civil.}

\subsubsection{Descripción.}

Parte de la doctrina en Alemania intenta fundamentar la posición de garante del fabricante a través de los deberes de conducta desarrollados por la jurisprudencia civil de la responsabilidad por el producto ${ }^{148}$. Como ya vimos, el Tribunal Estadual de Maguncia afirmó en el caso del espray para cuero la existencia de una posición de garante de los acusados, aludiendo - precisamente- al deber de retirada reconocido por los tribunales civiles $^{149}$. Es necesario preguntarse entonces si los deberes desarrollados en el marco de la responsabilidad civil por el producto permitirían efectivamente servir de apoyo a una obligación (penal) de evitación de resultados.

En el Derecho alemán, las acciones civiles para obtener una indemnización por los perjuicios causados por productos defectuosos pueden sustentarse tanto en la Ley de responsabilidad por el producto (ProdHaftG), como en la norma general de responsabilidad extracontractual prevista en el párrafo 1 del $§ 823$ del Código Civil (en adelante "BGB”) ${ }^{150}$.

\footnotetext{
${ }^{145}$ En este sentido expresamente MURMANN, Grundkurs, cit. nota n ${ }^{\circ} 115, \S 29$, número marginal 34, destacando que para que un dato fáctico permita fundar una posición de garante, necesariamente debe integrarse en la dinámica de la libertad del autor y de la víctima.

${ }^{146}$ Cfr. BOCK, Produktkriminalität, cit. nota n ${ }^{\circ} 13$, p. 111; SCHMUCKER, Die „,Dogmatik“, cit. nota $n^{\circ} 13$, p. 147.

${ }^{147}$ Véase, por ejemplo, KÜHL, Strafrecht, cit. nota n ${ }^{\circ} 40, \S 4$, número marginal 73, § 17, número marginal 47 y ss.; MURMANN, Grundkurs, cit. nota $\mathrm{n}^{\circ} 115, \S 23$, número marginal 102 y ss. En detalle sobre la relación de contrariedad al deber y los comportamientos alternativos conforme a Derecho FRISCH, Tatbestandsmäßiges Verhalten, cit. nota ${ }^{\circ} 59$, pp. 529 y ss.

${ }^{148}$ Véase BODE, "Zur strafrechtlichen Produkthaftung”, cit. nota n 64, p. 524; GOLL; WINKELBAUER, "§ 47. Materielle Voraussetzungen", cit. nota $\mathrm{n}^{\circ} 123$, número marginal 14 y s.; HÖHFELD, Strafrechtliche Produktverantwortung, cit. nota $\mathrm{n}^{\circ} 16$, p. 141 y ss. (aunque este autor también alude a criterios relacionados con la fuente de peligro situada en el propio ámbito de dominio para fundar la posición de garante del fabricante); SCHMIDT-SALZER, Joachim, Produkthaftung Bd. I Strafrecht, $2^{\text {a }}$ edición, Heidelberg: Recht und Wirtschaft, 1988. p. 35 y ss.

${ }^{149}$ LG Mainz resolución de fecha 16.01.1989, publicada en SCHMIDT-SALZER, Entscheidungssammlung, cit. nota $\mathrm{n}^{\circ} 18$, Nr. IV. 3. 22, p. 28.

${ }^{150}$ A diferencia del régimen de responsabilidad previsto en el $§ 823$ del Código Civil alemán, la Ley de responsabilidad por el producto contemplaría un sistema de responsabilidad por riesgo. A esta conclusión se puede llegar en atención a que el $\S 1$ de dicha ley solo exige para la indemnización de perjucios que la lesión
} 
Polít. crim. Vol. 12, № 23 (Julio 2017), Art. 1, pp. 1-55.

[http://www.politicacriminal.cl/Vol_12/n_23/Vol12N23A1.pdf]

Según esta disposición, el obligado a indemnizar el daño tiene que haber causado la lesión a un bien jurídico a través de una conducta objetivamente contraria a deber, que haya sido dolosa o negligente, produciéndose a consecuencia de ello un perjuicio. En una práctica jurisprudencial iniciada en los años sesenta del siglo pasado ${ }^{151}$, los tribunales civiles han categorizado aquellas exigencias objetivas de cuidado que todo fabricante debe cumplir ${ }^{152}$. Así, por ejemplo, tiene la obligación de diseñar el producto de acuerdo al estado más reciente de la técnica, garantizando de esta manera que el bien sea seguro en caso de ser utilizado de un modo racional por el consumidor (deber de diseño) ${ }^{153}$. Por otra parte, tiene el deber de informar acerca de todos los riesgos del producto que el consumidor no esté en condiciones de reconocer por sí mismo (deber de instrucción) ${ }^{154}$. El fabricante tiene la obligación, además, de indagar la existencia de riesgos que no hayan podido ser advertidos ni evitados al momento de la introducción del producto en el mercado, y de estudiar las eventuales consecuencias perjudiciales para los intereses de los consumidores que la utilización del bien trae consigo (deber de vigilancia) ${ }^{155}$. Si en el cumplimiento del deber de vigilancia se reconoce la existencia de un riesgo de desarrollo que no pueda ser eliminado a través de la mera advertencia a los consumidores, los tribunales han declarado que el fabricante tiene la obligación de retirar el producto del mercado ${ }^{156}$.

Las ventajas que tendría para el Derecho penal la adopción de los deberes de conducta desarrollados durante décadas por la jurisprudencia civil serían indiscutibles: la responsabilidad penal por el producto alcanzaría importantes cuotas de seguridad jurídica, se dotaría a los jueces con competencia en lo criminal de un acabado instrumental argumentativo y se garantizaría, además, el principio de unidad del ordenamiento jurídico, al desvalorarse civil y penalmente la misma infracción ${ }^{157}$. Sin embargo, existen opiniones contrarias a la introducción de criterios propios del Derecho civil para fundar una posición de garante del fabricante. Así, se señala que la responsabilidad civil del fabricante, fundada

al bien jurídico se haya causado a través de un defecto del producto, sin requerirse una conducta defectuosa individual o la infracción de un deber de cuidado (véase al respecto CONTRERAS, Normative Kriterien, cit. nota $\mathrm{n}^{\circ} 15$, p. 156).

${ }^{151}$ Fundamental en el desarrollo de la responsabilidad civil por el producto en Alemania fue el "caso de la peste del pollo" $($ BGHZ 51, $91=$ NJW 1969, 269 con comentario de Diederichsen = JZ 1969, 387 con comentario de Deutsch).

${ }^{152}$ Con la dictación de la Geräte- und Produktsicherheitsgesetz (Ley de seguridad de aparatos y productos) en el año 2004, varios de los deberes del fabricante que habían sido desarrollados por la jurisprudencia civil entre ellos los deberes de vigilancia, advertencia y retirada- quedaron positivizados. Tales deberes están contenidos actualmente en la Produktsicherheitsgesetz (Ley de seguridad de productos) del año 2011. Sobre los efectos de las normas pre-penales contenidas en la Produktsicherheitsgesetz para la concreción de los deberes jurídicos del fabricante véase CONTRERAS, Normative Kriterien, cit. nota n ${ }^{\circ} 15$, p. 120 y ss.

${ }^{153}$ BGHZ 104, 323, 326 y s.; BGH NJW 2009, 2952, 2952 y s.

${ }^{154}$ Véase al respecto BGH NJW 2009, 2952, 2954.

${ }^{155}$ Fundamentales BGHZ 80, 186, 191; BGH NJW 1981, 1606, 1607.

${ }^{156}$ Véase BGH NJW 2009, p. 1081; OLG Frankfurt VersR 1991, p. 1184; OLG Karlsruhe $N J W-R R$ 1995, 594, 597.

${ }^{157}$ En este sentido ALEXANDER, Thorsten, Die strafrechtliche Verantwortlichkeit für die Wahrung der Verkehrssicherungspflichten in Unternehmen, Herbolzheim: Centaurus, 2005, p. 59; GROßE VORHOLT, Behördliche Stellungnahmen, cit. nota ${ }^{\circ}$ 7, p. 162; HILGENDORF, Strafrechtliche Produzentenhaftung, cit. nota ${ }^{\circ}$ 53, p. 147; HOLTERMANN, Neue Lösungsansätze, cit. nota ${ }^{\circ}$ 7, p. 160; KUHLEN, Lothar, Fragen einer strafrechtlichen Produkthaftung, Heidelberg: Müller, 1989, p. 83; MAYER, Strafrechtliche Produktverantwortung, cit. nota $\mathrm{n}^{\circ} 14$, p. 236 y s. 
CONTRERAS, Lautaro. "La posición de garante del fabricante en el Derecho penal alemán”.

en el párrafo 1 del $\S 823$ BGB, ha devenido en una verdadera responsabilidad por riesgo, debido a la introducción por parte de la jurisprudencia de reglas probatorias especiales que favorecen la pretensión del consumidor ${ }^{158}$. Esto no sería admisible en materia penal, debido a la vigencia ilimitada del principio de presunción de inocencia. Por otra parte, se indica que los puntos de vista teleológicos bajo los cuales se concretan las normas de conducta en la responsabilidad civil por el producto serían muy distintos a los que deberían regir en el Derecho penal $^{159}$. De este modo, aspectos legítimos de repartición de riesgos propios del Derecho civil como, por ejemplo, la posibilidad que tiene el fabricante de contratar seguros frente a una eventual condena a pagar una indemnización de perjuicios, o la indudable mejor capacidad económica con que cuenta el productor (en comparación con el consumidor) para soportar el coste de los daños, representarían argumentos inutilizables en materia penal para fundar un mandato de evitación ${ }^{160}$. En contra de la asunción de los deberes desarrollados por la jurisprudencia civil para fundamentar una posición de garante se aduce, finalmente, que el Derecho civil de la responsabilidad extracontractual y el Derecho penal persiguen finalidades totalmente diversas ${ }^{161}$. Mientras el primero busca compensar los daños al patrimonio, el segundo tiene por objetivo proteger la vigencia de normas de conducta especialmente relevantes que ha sido puesta en tela de juicio por el infractor. Todas las razones anteriores explicarían por qué en el caso del espray para cuero el Tribunal Supremo Federal mostró sus dudas ante la posibilidad de invocar el deber civil de retirada para justificar la posición de garante del fabricante: "En efecto, más de uno

\footnotetext{
${ }^{158}$ En principio, un consumidor dañado por un producto defectuoso debería probar todos los presupuestos de la norma de sanción civil del párrafo 1 del $\S 823$ BGB para obtener una indemnización de perjuicios, incluyendo la lesión de un deber de cuidado y la imprudencia del fabricante. Sin embargo, la posibilidad de probar esos elementos en un caso de responsabilidad por el producto depende en buena medida de si el consumidor está en condiciones de esclarecer en detalle los procesos internos de la empresa; esto es evidentemente difícil, puesto que se trata de circunstancias respecto de las cuales el consumidor no cuenta con la necesaria información ( $B G H Z$ 51, 91, 104 y s.). Debido a ello, el Tribunal Supremo Federal alemán introdujo en el "caso de la peste del pollo" (BGHZ 51, 91 y ss.) una regla de inversión de la carga de la prueba en favor del consumidor, cuya aplicación ha mantenido a lo largo del tiempo. Conforme a ella, el consumidor debe probar el defecto del producto, la lesión del bien jurídico y la relación causal entre el defecto y la lesión ( $B G H Z$ 51, 91, 102, 104 y s; 80, 186, 196; 104, 323, 332), así como demostrar que las causas del daño que entran en consideración provienen del ámbito de riesgo por el cual debe responder el fabricante ( $B G H Z 51$, 91,$105 ; 80,186,196 ; 104,323,332 ; 114,284,295$ y s.). Probados tales hechos, la jurisprudencia ha indicado que corresponde al fabricante eximirse de responsabilidad, para lo cual tiene que demostrar que no existió una contrariedad a deber objetiva o imprudencia de su parte (BGHZ 51, 91, 102 y ss; 116, 104, 107 y ss.; BGH NJW 1999, 1028, 1029; 2004, 521, 522). Debido a estas modificaciones en el reparto de la carga de la prueba en el marco de la responsabilidad civil por el producto, se señala que el Tribunal Supremo Federal alemán ha creado - en los hechos- una responsabilidad extracontractual por riesgo, que prescinde de la culpa (en este sentido KRAAS, Maja, Produkthaftung und Warnhinweise Eine rechtsökonomische Analyse am Beispiel von Coca-Cola, Frankfurt am Main: Peter Lang, 2004, p. 93; LANDROCK, Gisela, "Das Produkthaftungsrecht im Lichte neuerer Gesetzgebung und Rechtsprechung", JA 2003, pp. 981-989, p. 988 y s.; SPINDLER, Gerald, “§ 823”, en: BAMBERGER, Heinz Georg ROTH, Herbert [Editores], Beck'scher Online-Kommentar BGB, $20^{\mathrm{a}}$ Edición, München: C. H. Beck, 2011, números marginales 480 y 552; WEI $\beta$, Die rechtliche Gewährleistung, cit. nota ${ }^{\circ} 1$, p. 439 y s.).

${ }^{159}$ Véase BLOY, "Die strafrechtliche Produkthaftung", cit. nota no 80, p. 43 y s.

${ }^{160}$ Así HÖHFELD, Strafrechtliche Produktverantwortung, cit. nota ${ }^{\circ}$ 16, p. 182; KUHLEN, Fragen, cit. nota $\mathrm{n}^{\circ} 157$, pp. 91 y 151; SCHUMANN, Strafrechtliches Handlungsunrecht, cit. nota $\mathrm{n}^{\circ} 75$, p. 117.

${ }^{161}$ BLOY, "Die strafrechtliche Produkthaftung", cit. nota $n^{\circ}$ 80, p. 43 y s.; DUTTGE, Gunnar, "Ein neuer Begriff der strafrechtlichen Fahrlässigkeit - Erwiderung auf Rolf D. Herzberg GA 2001, 568 ff.", GA 2003, pp. 451-468, p. 464.
} 
Polít. crim. Vol. 12, № 23 (Julio 2017), Art. 1, pp. 1-55.

[http://www.politicacriminal.cl/Vol_12/n_23/Vol12N23A1.pdf]

habla a favor de que los mismos deberes que son decisivos para la responsabilidad civil por el producto también constituyan el fundamento de la responsabilidad penal, sobre todo porque la obligación de indemnizar los daños causados por defectos del producto se concibe como un caso de responsabilidad delictual ( $\$ 823$ y ss. BGB)"162; sin embargo, “(...) los principios de responsabilidad del Derecho civil, orientados a la indemnización de perjuicios, no deben ser utilizados automáticamente para determinar la responsabilidad criminal" $" 163$.

Para los partidarios de fundar una posición de garante del fabricante a partir de los deberes desarrollados por la judicatura civil, ninguna de las objeciones expuestas tiene un carácter concluyente. Ellos señalan que si bien la responsabilidad por riesgo no es compatible con las exigencias que impone el principio de presunción de inocencia, tal forma de responsabilidad surgió de facto a partir de la introducción de reglas que alteraron la carga de la prueba en favor del consumidor. En un proceso penal es necesario que la parte acusadora pruebe el conjunto de presupuestos para aplicar la respectiva norma de sanción; una alteración de la carga de la prueba es inadmisible. No existiendo la posibilidad de modificar la carga probatoria, los peligros que supondría aplicar elementos de una responsabilidad por riesgo en el Derecho penal son mucho menores que los que a primera vista parecieran existir ${ }^{164}$. Por lo demás, una posición de garante basada en los deberes de conducta del Derecho civil no es suficiente por sí misma para condenar al fabricante; es necesario que concurra el resto de los elementos que integran la tipicidad del delito de omisión impropia, que la conducta sea además antijurídica y que esta se le pueda reprochar al fabricante ${ }^{165}$. Por otra parte, la circunstancia de que en el Derecho civil operen criterios teleológicos para concretar las normas de conducta que parecieran ser ajenos al sistema penal como, por ejemplo, el de reparto adecuado de riesgos económicos, tampoco impediría fundar una posición de garante a través de los deberes civiles de advertencia y retirada. Y es que el aspecto esencial de todos los deberes del fabricante desarrollados por la jurisprudencia civil consiste en su finalidad de protección frente a la lesión de bienes jurídicos, característica que las normas de conducta reforzadas penalmente también comparten $^{166}$. En consecuencia, no existiría obstáculo alguno para que la posición de garante del fabricante se fundara a través de los deberes establecidos por la jurisprudencia civil $^{167}$.

\footnotetext{
${ }^{162}$ BGHSt 37, 106, 115.

${ }^{163}$ BGHSt 37, 106, 115.

${ }^{164}$ En este sentido HÖHFELD, Strafrechtliche Produktverantwortung, cit. nota ${ }^{\circ}$ 16, p. 149.

165 Así HÖHFELD, Strafrechtliche Produktverantwortung, cit. nota ${ }^{\circ} 16$, p. 149.

${ }^{166}$ HÖHFELD, Strafrechtliche Produktverantwortung, cit. nota ${ }^{\circ} 16$, p. 149 y s.

${ }^{167}$ Véase BODE, "Zur strafrechtlichen Produkthaftung", cit. nota n 64, p. 524; GOLL; WINKELBAUER, "\$ 47. Materielle Voraussetzungen", cit. nota $\mathrm{n}^{\circ} 123$, número marginal 14 y s.; HÖHFELD, Strafrechtliche Produktverantwortung, cit. nota $\mathrm{n}^{\circ}$ 16, p. 141 y ss. (aunque este autor también alude a criterios propios de la fuente de peligro situada en el ámbito de dominio para fundar la posición de garante del fabricante); SCHMIDT-SALZER, Produkthaftung, cit. nota ${ }^{\circ} 148$, p. 35 y ss.
} 
CONTRERAS, Lautaro. "La posición de garante del fabricante en el Derecho penal alemán”.

4.2.2. Aplicación al caso del espray para cuero de la posición de garante basada en los deberes del fabricante desarrollados por la jurisprudencia civil.

Tal como argumentó el Tribunal Estadual de Maguncia, la posición de garante del fabricante podría fundarse en el deber de retirada reconocido por la jurisprudencia civil ${ }^{168}$. Una justificación semejante de tal posición de garante tiene claras ventajas frente a la injerencia. Así, los problemas relacionados con la contrariedad a deber de la comercialización previa del producto y con la falta de precisión del concepto de "conducta especialmente riesgosa" no se presentan ${ }^{169}$. Además, la asunción de criterios civiles para fundar el mandato de evitación de resultados permite considerar adecuadamente los cambios en la integración de los órganos de dirección, ya que tal mandato no está supeditado a una conducta anterior de carácter estrictamente individual ${ }^{170}$.

4.2.3. Apreciación crítica de la fundamentación de la posición de garante del fabricante a través de los deberes desarrollados por la jurisprudencia civil.

Sin perjuicio de reconocer las ventajas de fundamentar la posición de garante del fabricante a través de los deberes desarrollados por el Derecho civil, se trata de una argumentación que no puede ser compartida. En efecto, el que la responsabilidad civil por el producto haya reconocido la existencia de deberes jurídicos de advertencia y retirada, estimando que su infracción tiene que ser sancionada por la vía del $\S 823$ BGB, no significa que tenga que aceptarse forzosamente una posición de garante penal. Por el contrario, como existe una praxis que ha impuesto sanciones civiles en caso de quebrantamiento del deber de advertencia o retirada, puede plantearse la duda de si acaso la intervención penal por la vía de la omisión impropia es legítima, atendido que el ordenamiento jurídico cuenta con sanciones menos gravosas que las penales para reaccionar frente a la violación del deber ${ }^{171}$. De la existencia de un deber jurídico que forma parte integrante del orden de conducta, y que además ha sido reconocido por la jurisprudencia civil, solo podemos deducir lo siguiente: un fabricante que acate tal deber jamás podría ser castigado penalmente. Esto se explica por la naturaleza accesoria del Derecho penal (las conductas permitidas por el orden primario forman parte de la libertad general de actuación y no pueden ser penalizadas por el orden sancionatorio) ${ }^{172}$. Ahora bien, como el Derecho penal tiene además un carácter fragmentario, la coincidencia que debe existir entre el orden de conducta y el orden sancionatorio no implica de ninguna forma que toda infracción del orden de conducta deba

\footnotetext{
${ }^{168}$ LG Mainz resolución de fecha 16.01.1989, publicada en SCHMIDT-SALZER, Entscheidungssammlung, cit. nota $\mathrm{n}^{\circ} 18$, Nr. IV. 3. 22, p. 28.

${ }^{169}$ HÖHFELD, Strafrechtliche Produktverantwortung, cit. nota $n^{\circ} 16$, p. 147; cfr. además NEUDECKER, Gabriele, Die strafrechtliche Verantwortlichkeit der Mitglieder von Kollegialorganen dargestellt am Beispiel der Geschäftsleitungsgremien von Wirtschaftsunternehmen, Frankfurt am Main: Peter Lang, 1995, p. 114.

${ }^{170}$ HÖHFELD, Strafrechtliche Produktverantwortung, cit. nota ${ }^{\circ} 16$, p. 147.

${ }^{171}$ Esta cuestión, en todo caso, debería ser respondida afirmativamente. Porque si bien la reacción civil es menos gravosa para los derechos del fabricante que la penal, aquella no resulta tan eficaz para estabilizar los deberes de conducta puestos en tela de juicio (véase CONTRERAS, Normative Kriterien, cita nota $\mathrm{n}^{\circ} 15$, p. 32 y s.).

172 Expresamente FRISCH, Wolfgang, Verwaltungsakzessorietät und Tatbestandsverständnis im Umweltstrafrecht Zum Verhältnis von Umweltverwaltungsrecht und Strafrecht und zur strafrechtlichen Relevanz behördlicher Genehmigungen, Heidelberg: Müller, 1993, pp. 8 y 35; de acuerdo con él GROßE VORHOLT, Behördliche Stellungnahmen, cit. nota n ${ }^{\circ}$ 7, p. 163.
} 
Polít. crim. Vol. 12, № 23 (Julio 2017), Art. 1, pp. 1-55.

[http://www.politicacriminal.cl/Vol_12/n_23/Vol12N23A1.pdf]

ser sancionada criminalmente. Solo pueden recibir una sanción penal aquellas infracciones a deberes jurídicos especialmente graves. Los partidarios de la asunción de criterios propios del Derecho civil para fundar una posición de garante no aportan razones que expliquen por qué -atendido el carácter fragmentario del Derecho penal- la lesión a los deberes de advertencia y retirada tiene que ser sancionada no solo civilmente, sino también penalmente a través de los delitos de omisión impropia ${ }^{173}$. De alguna forma, su postura supone estimar que la sanción civil por sí sola pueda ser indicio del merecimiento de pena y ello no resulta admisible. Por otra parte, cualquier intento de fundamentación de la posición de garante del fabricante requiere explicar por qué el fabricante (y no el consumidor) es el especialmente competente para evitar la realización de los riesgos de desarrollo del producto (sobre esto, en detalle infra 5.). Los partidarios de acudir a los deberes civiles para fundar tal posición de garante no aportan argumentos en tal sentido; este es, precisamente, el aspecto más cuestionable de su posición.

En atención a lo expuesto, no es posible sostener la existencia de una posición de garante del fabricante a partir de los deberes desarrollados por la jurisprudencia civil ${ }^{174}$.

\subsection{Posición de garante del productor a través de la asunción de una función de protección.}

\subsubsection{Descripción.}

Como se sabe, un mandato de evitación de resultados puede surgir cuando el autor asume voluntariamente la protección de determinados bienes jurídicos, ya sea directamente frente

\footnotetext{
${ }^{173}$ Evidentemente, la infracción del deber de retirada tiene que ser castigada a través de los respectivos delitos de resultado, pero las razones para esto no son explicadas por los partidarios de la aplicación de criterios civiles para fundar la posición de garante del fabricante. Considerando la importancia de los bienes jurídicos en juego y la ausencia de otros medios efectivos de prevención, la aplicación del Derecho penal frente al quebrantamiento de un deber de retirada constituye un mecanismo -por regla general-idóneo, necesario y adecuado para la estabilización normativa.

${ }^{174}$ La mayoría de la doctrina rechaza la fundamentación de la posición de garante del fabricante a través de criterios del Derecho civil. Así BEULKE; BACHMANN, "Die Lederspray-Entscheidung", cit. nota n 64, p. 740; BOCK, Produktkriminalität, cit. nota ${ }^{\circ} 13$, p. 128; BOSCH, Organisationsverschulden, cit. nota $\mathrm{n}^{\circ} 14$, p. 187 y ss..; OTTO, "Die strafrechtliche Haftung", cit. nota ${ }^{\circ}$ 53, p. 293 y ss.; SCHMUCKER, Die „Dogmatik", cit. nota n ${ }^{\circ}$ 13, p. 135; SCHUMANN, Heribert, "Responsabilidad individual en la gestión de empresas - Observaciones sobre la Sentencia Erdal del Tribunal Supremo Federal alemán (BGH)”, en: MIR, Santiago; LUZÓN, Diego (Editores), Responsabilidad penal de las empresas y sus órganos y responsabilidad por el producto, Barcelona: Bosch, 1996, pp. 199-213, pp. 204 y s.; VOGEL, Joachim, "Stand und Entwicklung der strafrechtlichen Produkthaftung", en: RAUSCHER, Thomas (Editor), Festschrift für Werner Lorenz zum 80 Geburtstag, München: Sellier, 2001, pp. 65-82, p. 75; WEIßER, Kausalitäts- und Täterschaftsprobleme, cit. nota ${ }^{\circ} 24$, p. 61 ff. En opinión de Freund, el deber jurídico metapenal solo sirve de "muleta" en el ámbito de la omisión impropia; de su mera infracción no se sigue forzosamente la existencia de una responsabilidad especial (= una posición de garante) (FREUND, Erfolgsdelikt, cit. nota ${ }^{\circ}$ 82, p. 27). En un sentido similar NEUDECKER, Die strafrechtliche Verantwortlichkeit, cit. nota ${ }^{\circ} 169$, p. 119 y s. Cabe señalar que algunos autores que rechazan los deberes civiles como fundamento directo para una posición de garante del fabricante, aceptan que estos constituyen un indicio para la existencia de un deber de actuar. Según Roxin, tal posición de garante no se puede derivar directamente de los deberes civiles de vigilancia y retirada, pero estos representan elementos de una función de protección que tiene que atribuirse al fabricante (ROXIN, Strafrecht, cit. nota ${ }^{\circ} 40, \S 32$, número marginal 210). Por su parte, Weißer sostiene que los deberes de vigilancia del Derecho civil pueden servir como indicio de la existencia de un deber de garante penal (WEIßER, Kausalitäts- und Täterschaftsprobleme, cit. nota n ${ }^{\circ} 24$, p. 62).
} 
CONTRERAS, Lautaro. "La posición de garante del fabricante en el Derecho penal alemán”.

a la persona expuesta al peligro, ya sea frente a un tercero para salvaguardar a la persona sobre la que se cierne el peligro ${ }^{175}$. La existencia de múltiples fuentes de riesgo a las cuales uno se ve expuesto en la vida cotidiana obliga a que algunas personas (médicos, niñeras, guías de montaña, salvavidas, etc.) asuman un rol especial de protección ${ }^{176}$. El deber puede consistir en que el garante domine ciertas fuentes de peligro (por ejemplo, un animal peligroso dejado a cargo por el dueño) o se preocupe de la integridad de ciertos intereses (por ejemplo, la vida y salud individual del niño pequeño a quien se cuida en ausencia de los padres $)^{177}$. El fundamento de la posición de garante por asunción es la dependencia ético-social frente al bien protegido, en el sentido de una relación de expectativas recíprocas surgida de una situación de confianza luego de la aceptación voluntaria del deber de evitación ${ }^{178}$. El obligado a la protección responde por la realización de los peligros debido - precisamente- a que la confianza en el cumplimiento de la labor asumida ha llevado a la víctima a exponerse a ciertos riesgos o a rechazar la ayuda de otro, o al garante original - que ha reconocido una situación peligrosa- a prescindir de adoptar otras medidas de seguridad ${ }^{179}$. Es indispensable que la confianza haya hecho variar la situación del "beneficiario" de la promesa, quien, creyendo en ella, se somete a peligros que no es capaz de dominar por sí mismo (ej.: el alumno de clases de natación) o, debido a su desvalimiento, queda a cargo del garante y omite otras medidas de protección porque confía en su desempeño (ej.: el paciente) ${ }^{180}$. La asunción voluntaria de deberes de garante tendrá su origen frecuentemente en un contrato, aunque lo decisivo para que surja una responsabilidad especial no es que este se suscriba, sino que el deber de protección o ayuda efectivamente se asuma ${ }^{181}$. Tampoco es relevante que la relación contractual sea válida para la ley civil, puesto que no se trata de criminalizar el incumplimiento de una obligación contractual; lo que se sanciona penalmente es la lesión de una relación de dependencia que surge cuando la víctima se pone fácticamente bajo la protección del garante ${ }^{182}$.

\footnotetext{
${ }^{175}$ Véase, entre otros, KÜHL, Strafrecht, cit. nota n 40, § 18, número marginal 68 y ss; ROXIN, Strafrecht, cit. nota $\mathrm{n}^{\circ} 40, \S 32$, número marginal 53 y ss.

176 STREE; BOSCH, “StGB $§ 13 ”$, cit. nota n 32, número marginal 26.

${ }^{177}$ STREE; BOSCH, "StGB $§ 13$ ", cit. nota $n^{\circ} 32$, número marginal 26. Como señala Mayer, aunque la posición de garante por asunción normalmente tenga por objeto el resguardo de determinadas personas frente a peligros y se haya incardinado, por tanto, tradicionalmente dentro de la categoría de los garantes de protección, no hay ninguna razón evidente que impida que la función de resguardo asumida consista en el control de los peligros que provienen de una fuente riesgosa. De allí que, dependiendo de cuál sea el contenido de la obligación de resguardo, la posición de garante por asunción puede considerarse en las fuentes de protección o en las de vigilancia (MAYER, Strafrechtliche Produktverantwortung, cit. nota $n^{\circ} 14$, p. 251).

${ }_{178}$ MAYER, Strafrechtliche Produktverantwortung, cit. nota $\mathrm{n}^{\circ} 14$, p. 250.

${ }^{179}$ En este sentido OTTO, Grundkurs, cit. nota $\mathrm{n}^{\circ} 73, \S 9$, número marginal 64; similar JESCHECK; WEIGEND, Lehrbuch des Strafrechts, cit. nota $\mathrm{n}^{\circ} 32$, p. 623; idea ya expuesta por STREE, Walter, "Garantenstellung kraft Übernahme”, en: GEERDS, Friedrich; NAUCKE, Wolfgang (Editores), Beiträge zur gesamten Strafrechtswissen-schaft Festschrift für Hellmuth Mayer zum 70. Geburtstag am 1. Mai 1965, Berlin: Duncker \& Humblot, 1966, pp. 145-164, p. 158.

${ }^{180}$ Véase ROXIN, Strafrecht, cit. nota n 40, § 32, número marginal 55; STREE; BOSCH, "StGB $§ 13 ”$, cit. nota $\mathrm{n}^{\circ} 32$, número marginal 27.

${ }^{181}$ FRISTER, Derecho penal, cit. nota ${ }^{\circ} 118$, Capítulo 22, número marginal 42; KÜHL, Strafrecht, cit. nota $\mathrm{n}^{\circ} 40, \S 18$, número marginal 70; LEGE, Strafbarkeitsbegründende Rechtspflichten, cit. nota $\mathrm{n}^{\circ} 101, \mathrm{pp} .59$ y s.; MAYER, Strafrechtliche Produktverantwortung, cit. nota $\mathrm{n}^{\circ}$ 14, p. 251.

${ }^{182}$ En este sentido MURMANN, Grundkurs, cit. nota n ${ }^{\circ} 115, \S 29$, número marginal 49.
} 
Polít. crim. Vol. 12, № 23 (Julio 2017), Art. 1, pp. 1-55.

[http://www.politicacriminal.cl/Vol_12/n_23/Vol12N23A1.pdf]

Para algunos autores la asunción voluntaria de funciones de protección podría fundar la posición de garante del fabricante ${ }^{183}$. En la moderna sociedad de consumo el adquirente de bienes no tiene ninguna posibilidad de comprobar por sí mismo el carácter seguro de estos o descubrir riesgos de desarrollo inadvertidos al momento de la comercialización. Eso hace que el consumidor se vea obligado a confiar en que el fabricante no solo pondrá en el mercado productos seguros en caso de utilización racional, sino también que los vigilará activa y pasivamente, y ejecutará las respectivas medidas de evitación, en forma de acciones de advertencia o retirada ${ }^{184}$. El fabricante sabe también que el consumidor es incapaz de reconocer por sí mismo la existencia de riesgos de desarrollo ${ }^{185}$ y que la conservación de la vida y salud de este puede llegar a depender de que emprenda las respectivas medidas de evitación. Por eso, cada vez que introduce un bien en el mercado, el fabricante estaría haciendo una promesa tácita de protección al consumidor de que indagará la presencia de riesgos inadvertidos al momento de la comercialización y emprenderá, dado el caso, las necesarias medidas de advertencia y retirada ${ }^{186}$. Estas expectativas recíprocas entre fabricante y consumidor quedarían reflejadas en la existencia de deberes civiles de vigilancia, advertencia y retirada, de los cuales no se derivaría directamente una posición de garante, pero sí indicios de una función de protección que asume el fabricante ${ }^{187}$.

La posición de garante de asunción de una función de protección permite sin dificultades imponer deberes de actuar a los ejecutivos que asumen sus cargos después de la comercialización del producto, ya que la función de resguardo se relaciona con la posición actual en la empresa y no con una conducta previa ${ }^{188}$.

La idea de que la posición de garante del fabricante tendría su origen en la asunción de una función de protección fue planteada inicialmente en Alemania por Schünemann. Para este autor, el mandato de evitación de resultados que debe cumplir el fabricante sería un caso de asunción de protección debido al desvalimiento del bien jurídico, comparable con la posición de garante que tiene el médico o el dueño de un taller mecánico respecto de la vida y salud del paciente o del dueño de un vehículo, respectivamente ${ }^{189}$. El propietario de un automóvil -totalmente lego en asuntos de mecánica- debe confiar ciegamente en una revisión acuciosa por parte del dueño del taller, puesto que él no dispone de los

\footnotetext{
${ }^{183}$ Así MAYER, Strafrechtliche Produktverantwortung, cit. nota ${ }^{\circ}$ 14, p. 252 y ss.; ROXIN, Strafrecht, cit. nota $n^{\circ} 40, \S 32$, número marginal 210 y ss.; SCHMUCKER, Die „Dogmatik“, cit. nota ${ }^{\circ}$ 13, p. 153; SCHÜNEMANN, Bernd, "Unternehmenskriminalität”, en: ROXIN, Claus; WIDMAIER, Gunther (Editores), 50 Jahre Bundesgerichtshof Festgabe aus der Wissenschaft Band IV Strafrecht Strafprozessrecht, München: C. H. Beck, 2000, pp. 621-646, pp. 640 y s.; SCHÜNEMANN, Bernd, "Zur Garantenstellung beim unechten Unterlassungsdelikt”, en: BÖSE, Martin; STERNBERG-LIEBEN, Detlev (Editores), Grundlagen des Strafund Strafverfahrensrechts Festschrift für Knut Amelung zum 70. Geburtstag, Berlin: Duncker \& Humblot, 2009, pp. 303-323, pp. 317 y ss. (en publicaciones anteriores, Schünemann rechazó una posición de garante del fabricante, así SCHÜNEMANN, Bernd, "Zum gegenwärtigen Stand”, cit. nota n 53, p. 71).

${ }^{184}$ MAYER, Strafrechtliche Produktverantwortung, cit. nota ${ }^{\circ} 14$, p. 252 y s.; ROXIN, Strafrecht, cit. nota 40, § 32, número marginal 210.

${ }^{185}$ Véase nota $\mathrm{n}^{\circ} 2$.

${ }^{186}$ MAYER, Strafrechtliche Produktverantwortung, cit. nota ${ }^{\circ} 14$, p. 253.

${ }^{187}$ En este sentido ROXIN, Strafrecht, cit. nota 40, § 32, número marginal 210.

${ }^{188}$ Así lo destaca ROXIN, Strafrecht, cit. nota 40, § 32, número marginal 214.

${ }^{189}$ SCHÜNEMANN, "Unternehmenskriminalität”, cit. nota n 183, p. 640; SCHÜNEMANN, “Zur Garantenstellung”, cit. nota ${ }^{\circ} 183$, p. 317.
} 
CONTRERAS, Lautaro. "La posición de garante del fabricante en el Derecho penal alemán”.

conocimientos técnicos que permiten comprobar el estado del vehículo. De esta manera, renuncia a una revisión efectuada por él mismo y hace frente a su propio desvalimiento acudiendo a un especialista en mecánica ${ }^{190}$. Ese acto de confianza tácito, que vincula al dueño del automóvil y al propietario del taller, no es distinto al existente entre un consumidor y un fabricante. El consumidor renuncia a examinar él mismo el producto y confía en que el fabricante comprobará la existencia de riesgos de desarrollo, con lo que su ignorancia -como fundamento del resultado-queda por completo en manos del fabricante, quien adquiere un dominio sobre la misma ${ }^{191}$.

Para Schünemann, sin embargo, el fabricante solo es garante tratándose de productos de marca y está obligado únicamente a advertir a los consumidores de los riesgos de desarrollo que descubra, no teniendo deber alguno de retirar los bienes defectuosos del mercado. La exigencia del cumplimiento de obligaciones de evitación, limitada solo a los riesgos provenientes de productos de marca, se explicaría porque estos son los únicos que se publicitan y distribuyen con la promesa expresa o tácita de hacer un seguimiento de sus condiciones de seguridad incluso después de su comercialización ${ }^{192}$. El mayor precio de los productos de marca -en comparación a aquellos bienes sin marca- se justificaría porque incluye una "cuota específica" por la prestación adicional de cumplir una función de protección; en consecuencia, el consumidor que lo paga puede confiar en que el fabricante cumplirá precisamente su deber de vigilancia ${ }^{193}$. Si en el cumplimiento de este deber el fabricante descubre un peligro que no pudo ser cognoscible al momento de la comercialización, estaría obligado solo a la respectiva advertencia, no a la retirada del artículo. El mandato de evitación se agotaría en la advertencia porque, realizada esta, queda ya en manos del consumidor utilizar o no el producto defectuoso; las actuaciones del consumidor posteriores al aviso ya no se podrán imputar al fabricante ${ }^{194}$. Además, como el dominio del fabricante debido al desvalimiento del consumidor está condicionado por una ventaja informativa, una vez que el fabricante entrega al consumidor la información necesaria sobre el riesgo, desaparece el dominio y, con ello, la posición de garante ${ }^{195}$. La limitación del deber de evitar resultados a la mera advertencia tendría consagración legal en

${ }^{190}$ SCHÜNEMANN, “Zum gegenwärtigen Stand”, cit. nota $n^{\circ}$ 53, p. 70

${ }^{191}$ En este sentido SCHÜNEMANN, "Zum gegenwärtigen Stand”, cit. nota n 53, pp. 70 y s.

192 A diferencia de los productos de marca, los productos sin marca o "anónimos" no podrían ser individualizados por el fabricante o el consumidor, por lo que cualquier acción de advertencia luego del descubrimiento de un riesgo de desarrollo estaría condenada al fracaso (cfr. SCHÜNEMANN, "Zur Garantenstellung”, cit. nota $n^{\circ} 183$, p. 318). Tácitamente a favor de una limitación de la posición de garante del fabricante a los productos de marca ÍNIIGO, María Elena, La responsabilidad penal del fabricante por defectos de sus productos, Barcelona: Bosch, 2001, p. 283.

${ }^{193}$ Véase SCHÜNEMANN, "Unternehmenskriminalität", cit. nota n 183, p. 641; SCHÜNEMANN, "Zur Garantenstellung", cit. nota $\mathrm{n}^{\circ}$ 183, p. 317. Por deber de "vigilancia" debemos entender la obligación del fabricante de verificar la efectividad de todos los reclamos que lleguen a la empresa y que digan relación con defectos del producto que puedan desencadenar daños a los bienes jurídicos del consumidor (vigilancia pasiva), así como la obligación del fabricante de generar y valorar por sí mismo aquella información que le permita descubrir los riesgos del producto no reconocibles al momento de su introducción en el mercado (vigilancia activa). Sobre los deberes de vigilancia véase en detalle BODEWIG, Der Rückruf, cit. nota $n^{\circ} 2$, pp. 194 y ss.

${ }^{194}$ Así SCHÜNEMANN, "Unternehmenskriminalität”, cit. nota n 183, p. 638; SCHÜNEMANN, “Zur Garanten-stellung", cit. nota ${ }^{\circ} 183$, p. 318.

${ }^{195}$ En este sentido SCHÜNEMANN, “Zur Garantenstellung”, cit. nota n 183, p. 317 (pie de página 48). 
Polít. crim. Vol. 12, № 23 (Julio 2017), Art. 1, pp. 1-55.

[http://www.politicacriminal.cl/Vol_12/n_23/Vol12N23A1.pdf]

el Derecho chileno. En efecto, de acuerdo al art. 46 de la Ley $N^{\circ} 19.496$ sobre protección de los derechos de los consumidores, el fabricante de bienes que, con posterioridad a la introducción de ellos en el mercado, se percata de la existencia de peligros o riesgos no previstos oportunamente, debe cumplir (solo) con la respectiva obligación de advertencia a los consumidores; la ley no menciona expresamente una obligación de retirada.

\subsubsection{Aplicación de la teoría de la asunción de una función de protección en el caso del espray para} cuero.

En el caso del espray para cuero la posición de garante del fabricante podría haberse fundado a través de la idea de la asunción de una función de protección. Frente a los peligros no cognoscibles al momento de introducir un producto en el mercado, los consumidores de los aerosoles estaban en una posición de claro desvalimiento y confiaban en que, tanto la empresa fabricante como las filiales de distribución E. y S., ejecutarían las necesarias medidas de retirada, en caso de ser descubierto un riesgo de desarrollo. Los acusados asumieron una función de protección en favor de los consumidores, debiendo responder penalmente por delitos de omisión impropia.

\subsubsection{Apreciación crítica de la posición de garante por la asunción de una función de protección.}

Las ventajas que ofrece la teoría de la asunción de una función de protección frente a la injerencia para fundar la posición de garante del fabricante son importantes. Por una parte permite hacer responsable por omisión impropia al ejecutivo que asume su cargo después de la comercialización del producto, ya que el deber de evitación no descansa en una conducta previa. Por otra, no exige que la comercialización del producto haya sido contraria a deber para que el garante tenga la obligación de desplegar medidas de evitación.

Sin perjuicio de lo anterior, no es posible afirmar que los deberes de garante del fabricante tengan su origen en la asunción de una función de protección, ya que con ello se desconoce un presupuesto esencial de la fuente de garante que se está invocando. En efecto, como ya vimos, un elemento decisivo de la posición de garantía por asunción consiste en dar origen a un momento de peligro, que tiene lugar cuando una persona -confiando en que el garante asumirá la protección del bien jurídico o vigilará el foco de peligro-, se expone a ciertos riesgos, prescinde de ciertas medidas de protección u omite recurrir a otros para resguardar sus intereses ${ }^{196}$. Ahora bien, la exposición al peligro, la prescindencia de medidas de resguardo o la renuncia a pedir el auxilio de otros solo pueden tener lugar cuando la función de protección se asume efectivamente por el garante ${ }^{197}$; solo en ese instante se puede confiar razonablemente en que la tarea de protección será cumplida. Atendido el desconocimiento absoluto que tiene el consumidor de los procesos internos de la empresa y, en consecuencia, del hecho de estar o no el fabricante inmediatamente dispuesto a cumplir sus deberes de advertencia y retirada, aquel no puede saber si la asunción de la función de

\footnotetext{
${ }^{196}$ Expresamente en este sentido STREE, “Garantenstellung kraft Übernahme”, cit. nota n 179 , pp. 154 y s, 158.

${ }^{197}$ La confianza en la asunción de la tarea de protección recién está justificada cuando el garante efectivamente ha asumido su tarea (entre otros KÜHL, Strafrecht, cit. nota $n^{\circ} 40, \S 18$, número marginal 70).
} 
CONTRERAS, Lautaro. "La posición de garante del fabricante en el Derecho penal alemán”.

protección fue real. Sin ese antecedente, el consumidor no puede exponerse "confiadamente" al riesgo.

Por otra parte, fundar la posición de garante del fabricante en la asunción de una función de protección tampoco parece razonable desde la perspectiva de un adecuado resguardo de los intereses de los consumidores. Como ya vimos, Schünemann -uno de los principales defensores de la idea de la asunción- limita injustificadamente los deberes de garante del fabricante. Por una parte, no hay ninguna razón para no exigir a un fabricante de productos sin marca que vigile los riesgos de desarrollo y, dado el caso, advierta de los mismos al consumidor o incluso retire los artículos del mercado. La supuesta situación de desvalimiento del consumidor, a causa de su incapacidad de reconocer por sí mismo los riesgos del desarrollo, y la consiguiente posición de superioridad (= de dominio) del productor, es idéntica en los productos de marca y en aquellos que no la tienen. Por lo demás, un producto sin marca puede ser tanto o más peligroso para la vida y salud que uno que sí la posee. Piénsese solo en una empresa agrícola de mediano o gran tamaño que vende grandes cantidades de frutas y hortalizas a supermercados sin ningún signo que individualice el producto y que, luego de su comercialización, reconoce el carácter perjudicial para la salud de una determinada partida. ¿Existe alguna razón para que el Derecho no pueda exigir legítimamente a la empresa agrícola ejecutar una acción de advertencia o retirada? El que los productos con marca tengan habitualmente un mayor precio no significa que el consumidor esté pagando una "prestación adicional", consistente en la adopción de medidas de evitación en caso de ser necesario; el precio puede significar, simplemente, que el artículo tenga una mayor durabilidad u otorgue cierto "estatus"

Tampoco hay ninguna justificación para limitar, como lo hace Schünemann, la posición de garante del fabricante únicamente al cumplimiento de acciones de advertencia. Porque si se sostiene que el fabricante es garante, entonces como tal deberá desplegar las acciones que sean necesarias para la evitación del resultado en la situación respectiva, lo que incluye no solo medidas de advertencia, sino también de retirada ${ }^{199}$. En algunos casos una acción de retirada será la única medida que permitirá garantizar la incolumidad del bien jurídico. Así ocurrirá, por ejemplo, tratándose de productos de elevado precio, cuyo reemplazo o reparación no pueda financiar el consumidor; en estos casos no se puede descartar que el usuario - pese a una (mera) advertencia- se incline a seguir utilizando el bien ${ }^{200}$. Ni siquiera la circunstancia de que el Derecho positivo - como ocurre en el caso chileno con el art. 46 de la Ley $\mathrm{N}^{\circ}$ 19.496- solo mencione una obligación de advertencia frente al descubrimiento de riesgos no previstos oportunamente, sin aludir expresamente a un deber de retirada, nos puede llevar a negar la existencia de este. Primero, porque la legitimidad de la imposición de un mandato jurídico no depende de que este se encuentre positivizado; lo decisivo no es la consagración legal del deber, sino si este satisface principios de

\footnotetext{
${ }^{198}$ Véase ROXIN, Strafrecht, cit. nota 40, § 32, número marginal 213.

${ }^{199}$ De cualquier posición de garante se deriva la obligación de realizar aquellas acciones necesarias para evitar el resultado típico (véase ROXIN, Strafrecht, cit. nota n 40, § 31, número marginal 180), sin perjuicios de consideraciones posteriores de exigibilidad.

${ }^{200}$ En este sentido, entre otros, HERRMANN, Harald, "Die Rückrufhaftung des Produzenten", BB 1985, pp. 1801-1812, p. 1806; RETTENBECK, Stephan, Die Rückrufpflicht in der Produkthaftung Zugleich ein Beitrag zur EG-Richtlinie über die allgemeine Produktsicherheit vom 29. Juni 1992, Baden-Baden: Nomos, 1994, p. 71.
} 
Polít. crim. Vol. 12, № 23 (Julio 2017), Art. 1, pp. 1-55.

distribución adecuada de libertades y $\operatorname{cargas}^{201}$. Segundo, porque concluir de un texto legal que solo contempla expresamente la obligación de advertencia del fabricante (en caso de descubrir riesgos no previstos oportunamente), que el único deber jurídico que pesa sobre este sea el de dar aviso del peligro a los consumidores, tendría consecuencias inadmisibles; implicaría sostener - por ejemplo- que ante el descubrimiento de graves riesgos de desarrollo, el fabricante no tendría la obligación de paralizar de inmediato la producción o modificar sustancialmente el diseño del bien de consumo.

Por todas las consideraciones expuestas, no es posible fundamentar la posición de garante del fabricante en la asunción de una función de protección.

\section{Toma de postura.}

El caso del espray para el cuero demuestra que es posible introducir en el mercado productos cuyos riesgos para los consumidores -en caso de ser utilizados de un modo razonable- no sean cognoscibles ni evitables para el fabricante en el momento de la comercialización. En la medida que estos riesgos de desarrollo no logren ser reconocidos pese al cumplimiento de la exigencia debida, los resultados lesivos que provoquen no podrán generar responsabilidad criminal, puesto que ningún fabricante está obligado a impedir aquellos cursos peligrosos para la vida y salud de los consumidores que no puedan advertirse desde una perspectiva ex ante.

Ahora bien, cuando los riesgos de desarrollo ya son (o deben ser $^{202}$ ) cognoscibles para el fabricante y no es posible excluir que estos produzcan en el futuro muertes o lesiones de los consumidores, toda la dogmática alemana ${ }^{203}$ desarrollada a partir del caso del espray para el cuero afirma que el fabricante está obligado a ejecutar una acción de retirada, en caso que una mera advertencia del peligro no permita evitar el resultado. Existe consenso doctrinario, además, en que la posición de garante del productor no es susceptible de fundarse -en contra de lo que sostuvo el BGH en el caso del espray para cuero- en una acción previa infractora de deber, porque lo característico de los riesgos de desarrollo es que no puedan ser conocidos ni evitados pese al cumplimiento del cuidado debido.

La mayoría de la doctrina alemana ha afirmado la competencia del fabricante para excluir la realización de los riesgos de desarrollo acudiendo a categorías habitualmente aceptadas de posiciones de garante, sin desarrollar argumentaciones totalmente convincentes. La conclusión a la que la doctrina llega es correcta -a saber: sobre el fabricante pesa una obligación jurídica de actuar-; sin embargo, se trata de soluciones que se basan en premisas

\footnotetext{
${ }^{201}$ Cfr. FRISCH, Tatbestandsmäßiges Verhalten, cit. nota ${ }^{\circ}$ 59, p. 200.

${ }^{202}$ Es posible que el fabricante no advierta en un caso concreto los riesgos de desarrollo, pero deba advertirlos en el marco del cumplimiento de sus obligaciones de vigilancia. Sobre el alcance de los deberes de vigilancia véase supra nota $\mathrm{n}^{\circ} 193$.

${ }^{203}$ El único autor en Alemania que rechaza una posición de garante del fabricante es SAMSON, Erich, "Probleme", cit. nota ${ }^{\circ} 54$, p. 184, para quien un deber de retirada tendría que ser necesariamente previsto por el legislador. En favor de la creación de un tipo especial de omisión propia que castigue la violación de los deberes de advertencia y retirada se pronuncia SARRABAYROUSE, Eugenio, Responsabilidad penal por el producto, Buenos Aires: Ad-Hoc, 2007, p. 605. Un tipo de omisión propia semejante puede encontrarse en el art. 548 contenido en el proyecto de ley que establece un nuevo Código Penal (Boletín N. ${ }^{\circ}$ 9.274-07).
} 
CONTRERAS, Lautaro. "La posición de garante del fabricante en el Derecho penal alemán”.

conceptuales débiles o que resultan incoherentes con sus propios presupuestos teóricos ${ }^{204}$. Así, los esfuerzos por construir una obligación de salvamento del fabricante, sobre la base de una injerencia que renuncie a la contrariedad a deber de la conducta, se ven frustrados porque no logran precisar qué debe entenderse exactamente por actuar precedente "especialmente riesgoso o calificado"; además, solo permiten sustentar una obligación de actuar cuando el ejecutivo de la empresa fabricante - a cargo de la advertencia o retiradaha tenido intervención en la comercialización previa del producto (supra 3.3.). Por su parte, las teorías basadas en la fuente de peligro dentro del ámbito de dominio, y en la asunción de una función de protección, desatienden los presupuestos dogmáticos de las propias categorías que invocan. No es posible afirmar una relación de dominio con el producto si este ya abandonó - una vez que ha sido comercializado- el ámbito espacial de influencia sobre el cual se tiene la capacidad efectiva de anular peligros; cuando el producto deja ese ámbito, falta ya una premisa básica de los deberes de aseguramiento del tráfico (supra 4.1.3.). Tampoco es plausible sostener que la posición de garante derive de la asunción voluntaria de una función de protección, puesto que ello supondría necesariamete identificar un momento en que el consumidor -advirtiendo la asunción real de la función protectora- renuncia a adoptar él mismo medidas de cuidado; tal asunción real difícilmente podrá ser reconocida por el consumidor, quien no tiene ninguna capacidad de saber si al interior de la empresa existe la disposición de adoptar medidas de evitación (supra 4.3.3.). Por último, la propuesta de recurrir a los deberes civiles de advertencia y retirada para fundamentar una posición de garante no entrega argumentos materiales que expliquen por $q u e ́$ le incumbe al fabricante -y no al consumidor- evitar la realización de los riesgos de desarrollo; se afirma un deber de actuar en materia penal simplemente porque tal deber también ha sido reconocido por el Derecho Civil (supra 4.2.3.).

Afirmar que existen dificultades para justificar un deber de actuar del productor a través de las categorías tradicionalmente aceptadas de posiciones de garante, no significan negar la obligación de evitación de resultados de aquel. Ni el Derecho alemán -ni tampoco el chileno- cuentan con un sistema de numerus clausus de posiciones de garantía; lo que existe son modelos esencialmente casusísticos de fuentes de obligación jurídica de actuar, que han sido desarrolladas $-\mathrm{y}$ con el tiempo reconocidas- por la doctrina y la jurisprudencia, y que son susceptibles de ampliarse $e^{205}$.

\footnotetext{
${ }^{204}$ Como señala Bloy, los esfuerzos desplegados por la doctrina para responder la pregunta acerca de la posición de garante del fabricante se ven frustrados porque intentan justificar la obligación de actuar a través de alguna de las posiciones de garantía tradicionales (BLOY, "Die strafrechtliche Produkthaftung", cit. nota $\mathrm{n}^{\circ} 80$, p. 49 [pie de página 65]).

${ }^{205}$ En este sentido expresamente en el Derecho alemán BLOY, "Die strafrechtliche Produkthaftung", cit. nota $\mathrm{n}^{\circ}$ 80, p. 49 (pie de página 65). La afirmación de que no existe en el Derecho alemán o chileno un sistema de numerus clausus de posiciones de garante merece la siguiente explicación adicional: una vez que se acepta la posibilidad de equiparar valorativamente la producción y la no evitación del resultado típico, ya sea por la vía de una norma legal expresa, como la del § 13 del Código Penal alemán, o por la vía de la elaboración dogmática, como ocurre en el caso chileno -logrando salvar los problemas que presenta tal equiparación a la luz del principio de legalidad-, la construcción de las posiciones de garante específicas en virtud de las cuales un sujeto está obligado por el Derecho a evitar el resultado queda entregada a la doctrina y a la jurisprudencia (en definitiva, a la argumentación jurídica), no a la ley (cfr. POLITOFF, Sergio et al, Derecho penal chileno, cit. nota $\mathrm{n}^{\circ} 32$, p. 57 y s). Es cierto que en algunos ordenamientos jurídicos, como el español, existen normas del Derecho positivo que contienen una enumeración taxativa de posiciones de garante; eso no ha impedido, no obstante, que la doctrina afirme que se trata de listados meramente ejemplares (en este sentido, para el caso
} 
Polít. crim. Vol. 12, № 23 (Julio 2017), Art. 1, pp. 1-55.

[http://www.politicacriminal.cl/Vol_12/n_23/Vol12N23A1.pdf]

Para justificar los deberes de advertencia y retirada que pesan sobre el fabricante solo es necesario concentrarse en las pautas de carácter material que aporta la teoría general de las posiciones de garantía ${ }^{206}$. Por eso, conviene destacar lo siguiente: garante es aquel sujeto que tiene una responsabilidad especial por evitar que se produzcan determinados cursos causales peligrosos para bienes jurídicos de terceros ${ }^{207}$ Este es un asunto de naturaleza puramente normativa $^{208}$. La responsabilidad especial para impedir cursos lesivos puede tener su origen en una particular relación jurídica que tiene el garante con el lugar de destino del peligro que hay que evitar (garante de protección), o bien en un estrecho vínculo jurídico que une al garante con la fuente del peligro que hay que contener (garante de vigilancia $^{209}$. En uno u otro caso, la imposición de deberes de evitación de resultados requiere de legitimación, puesto que aquella representa siempre una restricción a la libertad de actuación del sujeto; de ahí que sea necesario aportar razones que justifiquen concluyentemente por qué -conforme a principios de distribución adecuada de libertades y de cargas- un sujeto es especialmente competente para evitar la materialización de ciertos riesgos $^{210}$. En el contexto de la responsabilidad penal por el producto, esto obliga a desarrollar argumentos que nos permitan afirmar que es al fabricante - y no al consumidora quien le incumbe evitar la realización de los riesgos de desarrollo (a continuación infra 5.1. y 5.2.).

\subsection{La responsabilidad especial fundada en la obtención de ventajas a partir del carácter tolerado de los riesgos de desarrollo.}

Ningún ordenamiento jurídico exige al fabricante que introduzca productos en el mercado solo cuando esté en condiciones de excluir por completo que estos adolecen de defectos o peligros. Así, por ejemplo, en el marco del proceso de diseño, al fabricante no se le impone la obligación de que someta el producto a pruebas durante largos años hasta que esté en condiciones de excluir todo tipo de riesgos; en el contexto de la fabricación, tampoco se le exige efectuar controles de calidad que permitan evitar cualquier defecto de producción imaginable $^{211}$. Esto sería, en ocasiones, técnicamente imposible, o bien elevaría los costos de diseño y fabricación de tal forma que se terminarían imponiendo cargas insoportables al

de España, véase SILVA, Jesús, El nuevo Código Penal Cinco cuestiones fundamentales, Barcelona: Bosch, 1997, pp. 68 y s.).

${ }^{206}$ En favor de acudir a la teoría general de las posiciones de garante para fundar la obligación de actuar del fabricante se manifestó Schünemann en el año 1995, criticando la postura del Tribunal Supremo Federal alemán en el caso del espray para cuero: “...el deber de retirada no se puede meter a presión en el corsé de la posición de garante por injerencia tradicional y debe ser visto (...) objetivamente como un nuevo tipo de garante, cuya legitimación solo puede entrar en consideración sobre la base de una teoría general de las posiciones de garante" (SCHÜNEMANN, "Zum gegenwärtigen Stand”, cit. nota n 53, p. 70, el destacado es nuestro); el autor, sin embargo, terminó negando en esa oportunidad una posición de garantía del fabricante, opinión que cambiaría años después.

${ }^{207}$ Ver FREUND, Erfolgsdelikt, cit. nota ${ }^{\circ} 82$, pp. 68 y ss.

${ }^{208}$ FREUND, Strafrecht, cit. nota ${ }^{\circ} 82, \S 6$, número marginal 25.

${ }^{209}$ Cfr. FREUND, Erfolgsdelikt, cit. nota n ${ }^{\circ} 82$, p. 156.

210 Cfr. MURMANN, Grundkurs, cit. nota $\mathrm{n}^{\circ} 115, \S 29$, número marginal 32; FRISCH, Wolfgang, "Problemas fundamentales de la responsabilidad penal de los órganos de dirección de la empresa Responsabilidad penal en el ámbito de la responsabilidad de la empresa y de la división del trabajo", en: MIR, Santiago LUZÓN, Diego (Editores), Responsabilidad penal de las empresas y sus órganos y responsabilidad por el producto, Barcelona: Bosch, 1996, pp. 99-127, p. 112.

${ }^{211}$ Véase BODEWIG, Der Rückruf, cit. nota n ${ }^{\circ} 2$, pp. 169 y s. 
CONTRERAS, Lautaro. "La posición de garante del fabricante en el Derecho penal alemán”.

ejercicio de la libertad económica del productor. La innovación técnica que muchas veces pretende alcanzar el fabricante también se vería seriamente perjudicada, así como los propios intereses de los consumidores en la adquisición de bienes a un precio razonable. Por eso, el Derecho solo le exige al productor que excluya los defectos de diseño y fabricación con un muy alto grado de probabilidad, aplicando el cuidado debido que corresponda al estado de la ciencia y de la técnica existente al momento de la comercialización del bien. Esto es así incluso tratándose de productos especialmente riesgosos, como los medicamentos: es cierto que el fabricante debe someterlos a muy exigentes pruebas y a numerosos estudios antes de introducirlos en el mercado; pero los deberes que impone el Derecho al productor farmacéutico se basan siempre en el estado de los conocimientos científicos existentes en el momento de la introducción del medicamento en el mercado, lo que no siempre permitirá excluir por completo el riesgo. Ejemplo: el efecto secundario carcinógeno de un fármaco utilizado por enfermos crónicos puede descubrirse años después de su primera comercialización, puesto que el específico tipo de cáncer que genera solo aparece luego de un uso muy prolongado en el tiempo, o porque las pruebas tóxico-farmacológicas y clínicas exigidas no fueron capaces de descubrir el efecto carcinógeno $^{212}$.

Los peligros que subsisten a pesar del cumplimiento del cuidado debido en el diseño y fabricación de un producto constituyen los riesgos de desarrollo. Mientras no sean (ni deban) ser cognoscibles, el fabricante no responde por tales riesgos, debiendo soportarlos el consumidor. Y es que el Derecho no puede obligar al fabricante a evitar cursos lesivos que no sean cognoscibles desde una perspectiva ex ante ${ }^{213}$; si lo obligara, le impondría un deber de conducta protegido penalmente sin tener la posibilidad de eliminar los riesgos que fundan la obligación de evitar el resultado ${ }^{214}$.

Ahora bien, todo aquel que obtiene ventajas de un riesgo creado y dominable por él tiene el deber de mantenerlo en la dimensión más reducida posible, adoptando las medidas de evitación necesarias ${ }^{215}$. Si el fabricante saca provecho (económico, relacionado con la innovación técnica, etc.) de la posibilidad que le otorga el ordenamiento jurídico de liberarse de parte del riesgo del producto, es legítimo que el Derecho le imponga la obligación correlativa de mantenerlo bajo control ${ }^{216}$. El fabricante no puede pretender beneficiarse de la facultad que le reconoce el ordenamiento jurídico de poner en el mercado productos que pueden adolecer de riesgos no reconocibles ( los que tiene que asumir el propio consumidor!), sin otorgar las debidas "contraprestaciones" $" 217$. Por eso, no solo debe

\footnotetext{
${ }^{212}$ Ejemplo tomado de FOERSTE, Ulrich, "§ 24. Verkehrspflichten im Bereich der Warenherstellung”, en: GRAF V. WESTPHALEN, Friedrich (Editor), Produkthaftungshandbuch, Tomo 1, 2ª edición, München: C. H. Beck, 1997, número marginal 83.

${ }^{213}$ Así, por lo demás, se desprende del inciso segundo del art. 47 de la Ley N. 19.496 sobre protección de los derechos de los consumidores.

${ }^{214}$ Cfr. BOSCH, Organisationsverschulden, cit. nota ${ }^{\circ} 14$, p. 198.

${ }^{215}$ En este sentido BODEWIG, Der Rückruf, cit. nota $\mathrm{n}^{\circ} 2$, p. 170, quien alude a la obtención de ventajas de la fuente de peligro como un criterio que permite justificar la imposición de un deber jurídico de retirada.

${ }^{216}$ Cfr. BODEWIG, Der Rückruf, cit. nota ${ }^{\circ} 2$, p. 170.

${ }^{217}$ Este argumento lo destacan correctamente los partidarios de fundar la posición de garante del fabricante en la injerencia, concebida como actuar previo especial o calificadamente riesgoso (así FREUND, Strafrecht, cit. nota $\mathrm{n}^{\circ} 82, \S 6$, número marginal 69). El problema es que lo incardinan en una posición de garante que
} 
Polít. crim. Vol. 12, № 23 (Julio 2017), Art. 1, pp. 1-55.

indagar después de la comercialización la existencia de riesgos de desarrollo -a través del cumplimiento de las respectivas medidas de vigilancia ${ }^{218}$-, sino que además está obligado a retirar el producto del mercado, en caso que este represente una amenaza seria a la vida o salud del consumidor que no pueda ser mitigada a través de una (simple) advertencia.

\subsection{La responsabilidad especial fundada en las expectativas de los consumidores.}

Los deberes jurídicos que pesan sobre los fabricantes -incluyendo los deberes de advertencia y retirada- hallan siempre su fundamento en las expectativas de los consumidores, quienes esperan adquirir productos que no les dañen en caso de ser utilizados de un modo razonable; ese es el supuesto bajo el cual los adquieren y utilizan. En caso de que no se puedan excluir absolutamente los peligros que surgen de la utilización razonable del producto, los consumidores esperan que el productor se los informe clara y detalladamente. Entre las expectativas de los usuarios también se encuentra la advertencia que el fabricante debe hacer respecto de los riesgos que han llegado a su conocimiento luego de introducir el producto en el mercado y, dado el caso, el retiro del comercio ${ }^{219}$. Se trata de expectativas de seguridad que no solo se refieren a los productos de marca: los consumidores esperan productos que no les causen lesiones o muertes con independencia de la denominación comercial del bien. La confianza del consumidor crea en favor del fabricante importantes espacios de desarrollo de libertad, al permitirle no solo vender sus productos, sino además en cantidades que de otro modo no podría alcanzar. El fabricante que quiere aprovechar las ventajas que las expectativas descritas traen consigo, debe cumplir con la respectiva "contraprestación", a saber: él está obligado a poner en el mercado productos seguros en caso de utilización racional y, si descubre con posterioridad a la comercialización un riesgo de desarrollo que no pueda ser controlado con una simple advertencia, está obligado a la retirada. El ordenamiento jurídico espera de quien asume el rol de fabricante que satisfaga las expectativas que su posición social genera en los consumidores.

\subsection{Consideraciones finales acerca de una posición de garante específica del fabricante.}

Los argumentos esgrimidos en los dos apartados anteriores permiten sostener que el fabricante tiene una responsabilidad especial por evitar que se realicen los riesgos de desarrollo, una vez que estos ya son cognoscibles. El provecho que obtiene el fabricante del carácter tolerado de tales riesgos, así como de las expectativas de los propios consumidores, lo obligan a emprender las respectivas medidas de advertencia y retirada. Quien pretende introducir productos en el mercado - ejerciendo de este modo su libertad económica- solo lo puede hacer bajo la condición de eliminar aquellos peligros que se vuelvan "visibles" con posterioridad a la comercialización.

tiene una base débil (insuficiente claridad del concepto riesgo "especial" o "calificado") y que no permite fundar una obligación de actuar del sujeto cuando este no ha participado en la comercialización previa del producto.

${ }^{218}$ Sobre el concepto de vigilancia véase supra nota $\mathrm{n}^{\circ} 193$.

${ }^{219}$ Véase FRISCH, Tatbestandsmäßiges Verhalten, cit. nota n ${ }^{\circ}$ 59, p. 199. 
CONTRERAS, Lautaro. "La posición de garante del fabricante en el Derecho penal alemán”.

Estamos frente a una posición de garante específica del fabricante, que no es posible de incardinar en alguna de las fuentes de garantía tradicionales, tales como la injerencia, la asunción de una función de protección o la fuente de peligro dentro del propio ámbito de dominio $^{220}$. Sin perjuicio de esto, el fabricante es en todo caso un garante de vigilancia ${ }^{221}$. Y es que resulta más o menos evidente que el fabricante no tiene la obligación -como sí la tiene un garante de protección- de preservar la vida y salud de una persona (en este caso, el consumidor) frente a todo tipo de ataques; su deber, por el contrario, busca mantener bajo control un determinado foco de peligro, representado por un producto que adolece de riesgos de desarrollo y que puede dañar a un sinnúmero de individuos. El fabricante no tiene una relación especial con el lugar de destino del peligro que debe evitarse, sino, por el contrario, con el origen del peligro que hay que mantener bajo control ${ }^{222}$.

Al igual que las teorías que ha desarrollado la doctrina alemana para fundar la posición de garante del fabricante, la propuesta planteada ofrece la ventaja de no requerir la contrariedad a deber de la conducta previa del fabricante para afirmar su obligación de actuar. Pero además -y a diferencia de las propuestas basadas en la injerencia concebida como actuar previo generador de un riesgo especial o calificado-, se trata de una solución que no se sustenta en una conducta anterior imputable a un individuo en particular. Esto permite sostener una posición de garante también respecto de aquella o aquellas personas que no tuvieron ninguna intervención en la comercialización previa del producto.

Por otra parte, la solución propuesta no restringe el deber de garante del fabricante a los productos de marca, puesto que las expectativas de seguridad de los consumidores se refieren a toda clase de artículos, con independencia de que exista una denominación o signo que permita asociar el producto a una empresa. Tampoco hay una limitación relativa a la forma en que el garante debe evitar el resultado, una vez que los riesgos de desarrollo se han vuelto cognoscibles. Dependiendo de cuál sea la reacción idónea para evitar el daño a los bienes jurídicos de los consumidores, el garante deberá retirar el producto del mercado y no simplemente advertir de sus peligros. Eso es lo que el consumidor precisamente espera: que el fabricante haga lo necesario para evitar la realización de los riesgos del desarrollo.

Una posición de garante específica del fabricante, surgida del especial provecho que este obtiene de los riesgos de desarrollo y de las expectativas de los consumidores, hubiera permitido - sin dificultad- fundar en el caso del espray para cuero la obligación de retirada que pesaba sobre los acusados.

\footnotetext{
${ }^{220}$ En el mismo sentido BEULKE; BACHMANN, “Die Lederspray-Entscheidung”, cit. nota n 64, p. 740, quienes también hablan de una "posición de garante específica del fabricante".

${ }^{221}$ A favor también de reconocer una posición de garante específica del fabricante y clasificarla dentro del grupo de los garantes de vigilancia WESSELS, Johannes et al, Strafrecht Allgemeiner Teil Die Straftat und ihr Aufbau, 44 a edición, Heidelberg: Müller, 2014, número marginal 716.

${ }^{222}$ Cfr. FREUND, Erfolgsdelikt, cit. nota $\mathrm{n}^{\circ}$ 82, p. 156, para quien la diferencia básica entre los garantes de protección y de vigilancia consiste - precisamente- en que mientras los primeros tiene una relación especial con el lugar de destino del peligro que debe evitarse, los segundos tienen un vínculo especial con el origen del peligro que hay que contener.
} 
Polít. crim. Vol. 12, № 23 (Julio 2017), Art. 1, pp. 1-55.

[http://www.politicacriminal.cl/Vol_12/n_23/Vol12N23A1.pdf]

\section{BIBLIOGRAFÍA CITADA}

ALEXANDER, Thorsten, Die strafrechtliche Verantwortlichkeit für die Wahrung der Verkehrssicherungspflichten in Unternehmen, Herbolzheim: Centaurus, 2005.

ARZT, Gunther, "Zur Garantenstellung beim unechten Unterlassungsdelikt", JA 1980, pp. 553-561, 647-654 y 712-717.

BEULKE, Werner; BACHMANN, Gregor, "Die Lederspray-Entscheidung - BGHSt 37, 106", JuS 1992, pp. 737-744.

BLOY, René, "Die strafrechtliche Produkthaftung auf dem Prüfstand der Dogmatik", en: BLOY, René et al (Editores), Gerechte Strafe und legitimes Strafrecht Festschrift für Manfred Maiwald zum 75. Geburtstag, Berlin: Duncker \& Humblot, 2010, p. 35-59.

BOCK, Barbara, Produktkriminalität und Unterlassen, Aachen: Shaker, 1997.

BODE, Bernd-Dieter, "Zur strafrechtlichen Produkthaftung", en: GEI $\beta$, Karlmann et al (Editores), Festschrift aus Anlaß des fünfzigjährigen Bestehens von Bundesgerichtshof, Bundesanwaltschaft und Rechtsanwaltschaft beim Bundesgerichtshof, Köln: Carl Heymanns, 2000, pp. 515-529.

BODEWIG, Theo, Der Rückruf fehlerhafter Produkte Eine Untersuchung der Rückrufpflichten und Rückrufansprüche nach dem Recht Deutschlands, der Europäischen Union und der USA, Tübingen: Mohr Siebeck, 1999.

BOSCH, Nikolaus, Organisationsverschulden in Unternehmen, Baden-Baden: Nomos, 2002.

BRAMMSEN, Joerg, "Strafrechtliche Rückrufpflichten bei fehlerhaften Produkten?", GA 1993, pp. 97-120.

,"Unterlassungshaftung in formalen Organisationen", en: AMELUNG, Knut (Editor), Individuelle Verantwortung und Beteiligungsverhältnisse bei Straftaten in bürokratischen Organisationen des Staates, der Wirtschaft und der Gesellschaft, Sinzheim: Pro Universitate, 2000, pp. 105-144.

BRUNS, Hans-Jürgen, "Ungeklärte materiellrechtliche Fragen des Contergan-Prozesses", en: LÜTTGER, Hans et al (Editores), Festschrift für Ernst Heinitz zum 70. Geburtstag, Berlin: Walter de Gruyter, 1972, pp. 317-340.

BUSCH, Ralf, Unternehmen und Umweltstrafrecht, Osnabrück: Universitätsverlag Rasch, 1997.

COLUSSI, Marc, Produzentenkriminalität und strafrechtliche Verantwortung, Frankfurt am Main: Peter Lang, 2003.

CONTRERAS, Lautaro, Normative Kriterien zur Bestimmung der Sorgfaltspflichten des Produzenten, Berlin: Duncker \& Humblot, 2012.

, "La responsabilidad penal del fabricante por la infracción de sus deberes de vigilancia, advertencia y retirada", Polít. crim. n ${ }^{\circ} 19$ (Julio 2015), pp. 266-296, en: http://www.politicacriminal.cl/Vol_10/n_19/Vol10N19A9.pdf [visitado el 15/09/16].

CORRAL, Hernán, Responsabilidad por productos defectuosos Análisis y propuestas para el Derecho Civil y de Consumo en Chile, Santiago de Chile: Legal Publishing Chile, 2011.

DEUTSCHER, Jörg; KÖRNER, Peter, "Die strafrechtliche Produktverantwortung von Mitgliedern kollegialer Geschäftsleitungsorgane", wistra 1996, pp. 292-302 y 327334. 
CONTRERAS, Lautaro. "La posición de garante del fabricante en el Derecho penal alemán”.

DOMEIER, Danja, Gesundheitsschutz und Lebensmittelstrafrecht, Frankfurt am Main: Peter Lang, 1999.

DREHER, Meinrad, "Die persönliche Verantwortlichkeit von Geschäftsleitern nach außen und die innergesellschaftliche Aufgabenteilung", ZGR 1992, pp. 22-63.

DUTTGE, Gunnar, "Ein neuer Begriff der strafrechtlichen Fahrlässigkeit - Erwiderung auf Rolf D. Herzberg GA 2001, 568 ff.", GA 2003, pp. 451-468.

EICHINGER, Harald, Die strafrechtliche Produkthaftung im deutschen im Vergleich zum anglo-amerikanischen Recht, Frankfurt am Main: Peter Lang, 1997.

FOERSTE, Ulrich, "§ 24. Verkehrspflichten im Bereich der Warenherstellung”, en: GRAF V. WESTPHALEN, Friedrich (Editor), Produkthaftungshandbuch, Tomo 1, $2^{\mathrm{a}}$ edición, München: C. H. Beck, 1997.

FREUND, Georg, Erfolgsdelikt und Unterlassen, Köln: Heymann, 1992.

, "Täuschungsschutz und Lebensmittelstrafrecht - Grundlagen und Perspektiven", ZLR 1994, pp. 261-304.

, Strafrecht Allgemeiner Teil, $2^{\text {a }}$ edición, Berlin: Springer, 2009.

, "StGB § 13 Begehen durch Unterlassen", en: JOECKS, Wolfgang; MIEBACH, Klaus (Editores), Münchener Kommentar zum Strafgesetzbuch, Tomo 1, 2a edición, München: C. H. Beck, 2011.

FRISCH, Wolfgang, Tatbestandsmäßiges Verhalten und Zurechnung des Erfolgs, Heidelberg: Müller, 1988.

, Verwaltungsakzessorietät und Tatbestandsverständnis im Umweltstrafrecht Zum Verhältnis von Umweltverwaltungsrecht und Strafrecht und zur strafrechtlichen Relevanz behördlicher Genehmigungen, Heidelberg: Müller, 1993.

, "Straftat und Straftatsystem", en: WOLTER, Jürgen; FREUND, Georg (Editores), Straftat, Strafzumessung und Strafprozeß im gesamten Strafrechtssystem, Heidelberg: Müller, 1996, pp. 135-210.

"Problemas fundamentales de la responsabilidad penal de los órganos de dirección de la empresa - Responsabilidad penal en el ámbito de la responsabilidad de la empresa y de la división del trabajo", en: MIR, Santiago LUZÓN, Diego (Editores), Responsabilidad penal de las empresas y sus órganos y responsabilidad por el producto, Barcelona: Bosch, 1996, pp. 99-127.

FRISTER, Helmut, Derecho penal Parte General, traducción de la $4^{\text {a }}$ edición alemana, Buenos Aires: Hammurabi, 2011.

GIMBERNAT, Enrique, "La omisión impropia en la dogmática penal alemana. Una exposición", ADPCP, VOL. L, 1997, pp. 5-112.

GOLL, Eberhard WINKEL-BAUER, Wolfgang, "§ 47. Materielle Voraussetzungen der strafrechtlichen Verantwortung für fehlerhafte Produkte", en: GRAF V. WESTPHALEN, Friedrich (Editor), Produkthaftungshandbuch, Tomo 1, 2a edición, München: C. H. Beck, 1997.

GROSMAN, Denise, Decisiones colegiadas en la responsabilidad penal por el producto, Memoria para optar al grado de Licenciada en Ciencias Jurídicas y Sociales, Universidad de Chile, Santiago de Chile, 2016.

GROßE VORHOLT, André, Behördliche Stellungnahmen in der strafrechtlichen Produkthaftung Zur Konkretisierung von Sorgfaltspflichten bei Risikoentscheidungen, Baden-Baden: Nomos, 1997. 
Polít. crim. Vol. 12, № 23 (Julio 2017), Art. 1, pp. 1-55.

[http://www.politicacriminal.cl/Vol_12/n_23/Vol12N23A1.pdf]

HASSEMER, Winfried, Produktverantwortung im modernen Strafrecht, $2^{\mathrm{a}}$ edición, Heidelberg: Müller, 1996.

HERNÁNDEZ, Héctor, "El problema de la "causalidad general" en el derecho penal chileno (con ocasión del art. 232 del Anteproyecto de Nuevo Código Penal)", Polít. crim. $\mathrm{n}^{\circ} 1$ (2006), pp. 1-33 en: http://www.politicacriminal.cl/n_01/pdf_01/a_7.pdf [visitado el 15/09/16].

,“Art. 10", en: COUSO, Jaime; HERNÁNDEZ, Héctor (Editores), Código Penal comentado, Santiago de Chile: Legal Publishing, 2011, pp. 7-105.

HERRMANN, Harald, "Die Rückrufhaftung des Produzenten", BB 1985, pp. 1801-1812.

HERZBERG, Rolf Dietrich, Die Unterlassung im Strafrecht und das Garantenprinzip, Berlin: Walter de Gruyter, 1972.

HILGENDORF, Eric, Strafrechtliche Produzentenhaftung in der "Risikogesellschaft", Ber-lin: Duncker \& Humblot, 1993.

,"Der gesetzmäßige Zusammenhang im Sinne der modernen Kausallehre", Jura 1995, pp. 514-522.

HÖHFELD, Hendrik, Strafrechtliche Produktverantwortung und Zivilrecht, Berlin: Springer, 1999.

HOLTERMANN, Christian, Neue Lösungsansätze zur strafrechtlichen Produkthaftung Eine Untersuchung unter Heranziehung des Tatbestandes der gemeingefährlichen Vergiftung § 314 Abs. 1 Nr. 2 StGB, Baden-Baden: Nomos, 2007.

HONORES, Rodrigo, Problemas sobre la posición de garante del fabricante en la responsabilidad por el producto, Memoria para optar al grado de Licenciado en Ciencias Jurídicas y Sociales, Universidad de Chile, Santiago de Chile, 2015.

HORN, Eckhard, "Strafbares Fehlverhalten von Genehmigungs- und Aufsichtsbehörden?", NJW 1981, pp. 1-11.

HOYER, Andreas, "Die traditionelle Strafrechtsdogmatik vor neuen Herausforderungen: Probleme der strafrechtlichen Produkthaftung", GA 1996, pp. 160-178.

HUFEN, Friedhelm, Verfassungsrechtliche Maßstäbe und Grenzen lebensmittelstrafrechtlicher Verantwortung Zur Bestimmtheit, Differenziertheit und Verhältnismäßigkeit berufsregelnder Risikoverteilung, Baden-Baden: Nomos, 1987. , Staatsrecht II Grundrechte, $4^{\mathrm{a}}$ edición, München: C. H. Beck, 2014.

ÍNIGO, María Elena, La responsabilidad penal del fabricante por defectos de sus productos, Barcelona: Bosch, 2001.

IZQUIERDO, Cristóbal, "Comisión por omisión. Algunas consideraciones sobre la injerencia", Revista Chilena de Derecho, vol. 33 N² 2, 2006, pp. 329-343.

JAKOBS, Günther, Strafrecht Allgemeiner Teil, $2^{\mathrm{a}}$ edición, Berlin: Walter de Gruyter, 1991.

, "Teoría y praxis de la injerencia", ADPCP 1999, Vol. LII, 1999, pp. 17-50.

"Die Ingerenz in der Rechtsprechung des Bundesgerichtshofs", en: ROXIN, Claus; WIDMAIER, Gunther (Editores), 50 Jahre Bundesgerichtshof Festgabe aus der Wissenschaft Band IV Strafrecht Strafprozessrecht, München: C. H. Beck, 2000, pp. 29-49.

JASCH, Michael, “Übernahme von Garantenpflichten aus Ingerenz?", NStZ 2005, pp. 8-13. JESCHECK, Hans-Heinrich, "StGB § 13 Begehen durch Unterlassen", en: JÄHNKE, Burkhard et al (Editores), Strafgesetzbuch Leipziger Kommentar Großkommentar, $11^{a}$ edición, Berlin: Walter de Gruyter, 2003. 
CONTRERAS, Lautaro. "La posición de garante del fabricante en el Derecho penal alemán".

JESCHECK, Hans-Heinrich; WEIGEND, Thomas, Lehrbuch des Strafrechts Allgemeiner Teil, $5^{\text {a }}$ edición, Berlin: Duncker \& Humblot, 1996.

JUANATEY, Carmen, "Responsabilidad penal omisiva del fabricante o productor por los daños a la salud derivados de productos introducidos correctamente en el mercado", ADPCP VOL. LVII, 2004, pp. 53-75.

KAUFMANN, Armin, "Tatbestandsmäßigkeit und Verursachung im Contergan-Verfahren - Folgerungen für das geltende Recht und für die Gesetzgebung”, JZ 1971, pp. 569576.

KAUFMANN, Arthur; HASSEMER, Winfried, "Der Praktische Fall/Strafrecht - Der überfallende Spaziergänger”, JuS 1964, pp. 151-157.

KÖHLER, Michael, Strafrecht Allgemeiner Teil, Berlin: Springer, 1997.

KRAAS, Maja, Produkthaftung und Warnhinweise Eine rechtsökonomische Analyse am Beispiel von Coca-Cola, Frankfurt am Main: Peter Lang, 2004.

KÜHL, Kristian, Strafrecht Allgemeiner Teil, $7^{\mathrm{a}}$ edición, München: Vahlen, 2012. ,"StGB § 13 Begehen durch Unterlassen”, en: Lackner/Kühl Strafgesetzbuch Kommentar, $28^{\mathrm{a}}$ edición, München: C. H. Beck, 2014.

KUHLEN, Lothar, Fragen einer strafrechtlichen Produkthaftung, Heidelberg: Müller, 1989.

, "Strafhaftung bei unterlassenem Rückruf gesundheitsgefährdender Produkte Zugleich Anmerkung zum Urteil des BGH vom 6. 7. 1990 - 2 StR 549/89 (NStZ 1990, 588)", NStZ 1990, pp. 566-570.

, "1.Kapitel Strafrechtliche Produkthaftung", en: ACHENBACH, Hans et al (Editores), Handbuch Wirtschaftsstrafrecht, 4a edición, Heidelberg: Müller, 2015.

LANDROCK, Gisela, "Das Produkthaftungsrecht im Lichte neuerer Gesetzgebung und Rechtsprechung", JA 2003, pp. 981-989.

LEGE, Micha Alexander, Strafbarkeitsbegründende Rechtspflichten zur Abwendung von Schäden durch gefährliche Produkte, insbesondere zum Rückruf rechtsgutsgefährdender Produkte, Tübingen: Köhler-Druck, 2000.

MAIWALD, Manfred, "Grundlagenproblemen der Unterlassungsdelikte", JuS 1981, pp. 473-483.

MAYER, Michael, Strafrechtliche Produktverantwortung bei Arzneimittelschäden Ein Beitrag zur Abgrenzung der Verantwortungsbereiche im Arzneiwesen aus strafrechtlicher Sicht, Berlin: Springer, 2008.

MEIER, Bern-Dieter, "Verbraucherschutz durch Strafrecht? Überlegungen zur strafrechtlichen Produkthaftung nach der „Lederspray“ - Entscheidung des BGH”, NJW 1992, pp. 3193-3199.

MEINBERG, Volker, “Amtsträgerstrafbarkeit bei Umweltbehörden”, NJW 1986, pp. 22202228.

MERA, Jorge, "Los medios en el delito de lesiones graves (Art. 397 del C.P.)", Revista de Ciencias Penales, 1975, Tomo XXXIV, pp. 163-200.

MIR, Santiago, "Die ex ante - Betrachtung im Strafrecht", en: VOGLER, Theo, Festschrift für Hans-Heinrich Jescheck zum 70. Geburtstag, Tomo I, Berlin: Duncker \& Humblot, 1985. pp. 337-356.

MÜNZBERG, Wolfgang, Verhalten und Erfolg als Grundlagen der Rechtswidrigkeit und Haftung, Frankfurt am Main: Klostermann, 1966.

MURMANN, Uwe, Grundkurs Strafrecht, 2ª edición, München: C. H. Beck, 2013. 
Polít. crim. Vol. 12, № 23 (Julio 2017), Art. 1, pp. 1-55.

[http://www.politicacriminal.cl/Vol_12/n_23/Vol12N23A1.pdf]

NEUDECKER, Gabriele, Die strafrechtliche Verantwortlichkeit der Mitglieder von Kollegialorganen dargestellt am Beispiel der Geschäftsleitungsgremien von Wirtschaftsunternehmen, Frankfurt am Main: Peter Lang, 1995.

OTTO, Harro, "Die strafrechtliche Haftung für die Auslieferung gefährlicher Produkte", en: WEIGEND, Thomas; KÜPPER, Georg (Editores), Festschrift für Hans Joachim Hirsch zum 70. Geburtstag am 11. April 1999, Berlin: Walter de Gruyter, 1999, pp. 291-312.

, Grundkurs Strafrecht, $7^{\mathrm{a}}$ edición, Berlin: Walter de Gruyter, 2004.

POLITOFF, Sergio et al, Derecho penal chileno Parte Especial Delitos contra el individuo en sus condiciones físicas, $2^{\mathrm{a}}$ edición, Santiago de Chile: Editorial Jurídica de Chile, 1993.

POLITOFF, Sergio et al, Lecciones de Derecho penal chileno Parte General, $2^{\mathrm{a}}$ edición, Santiago de Chile: Editorial Jurídica de Chile, 2004.

PUPPE, Ingeborg, “Anmerkungen zu BHGSt 37, 106”, JR 1992. pp. 30-34.

RADTKE, Henning, "StGB § 14 Handeln für einen anderen", en: JOECKS, Wolfgang; MIEBACH, Klaus (Editores), Münchener Kommentar zum Strafgesetzbuch, Tomo 1, $2^{\mathrm{a}}$ edición, München: C. H. Beck, 2011.

RANSIEK, Andreas, "Zur deliktischen Eigenhaftung des GmbH-Geschäftsführers aus strafrechtlicher Sicht", ZGR 1992, pp. 203-231.

, Unternehmensstrafrecht Strafrecht Verfassungsrecht Regelungsalternativen, Heidelberg: Müller, 1996.

RETTENBECK, Stephan, Die Rückrufpflicht in der Produkthaftung Zugleich ein Beitrag zur EG-Richtlinie über die allgemeine Produktsicherheit vom 29. Juni 1992, BadenBaden: Nomos, 1994.

REUS, Katharina, Das Recht in der Risikogesellschaft Der Beitrag des Strafrechts zum Schutz vor modernen Produktgefahren, Berlin: Duncker \& Humblot, 2010.

ROXIN, Claus, Strafrecht Allgemeiner Teil, Tomo 2, München: C. H. Beck, 2003.

RUDOLPHI, Hans-Joachim, "Der Zweck staatlichen Strafrechts und die strafrechtlichen Zurechnungsformen", en: SCHÜNEMANN, Bernd (Editor), Grundfragen des modernen Strafrechtssystems, Berlin: Walter de Gruyter, 1984, pp. 69-84.

, “\$ 13”, en: RUDOLPHI, Hans-Joachim et al (Editores), SK StGB Systematischer Kommentar zum Strafgesetzbuch, Tomo I, $7^{\mathrm{a}}$ edición, en parte $8^{\mathrm{a}}$ edición, actualizado a octubre de 2005. Neuwied: Carl Heymanns.

SALAZAR, Andrés. "El delito de mantención de la venta de alimentos defectuosos al público: Una revisión del artículo 315 del Código Penal a partir de la teoría de las presunciones y de la dogmática de los delitos de omisión propia”, Polít. crim. $\mathrm{n}^{\circ} 19$ (Julio 2015), pp. 318-361, en: http://www.politicacriminal.cl/Vol_10/n_19/Vol10N19A11.pdf [visitado el 15/09/16].

SAMSON, Erich, "Probleme strafrechtlicher Produkthaftung", StV 1991, pp. 182-186.

SCHMIDT-SALZER, Joachim, Entscheidungssammlung Produkthaftung, Bd. IV: Mit einer Einführung und Urteilsanmerkungen, Strafrechtliche Entscheidungen, Gesamtregister Bd. I-IV, Berlin: Schweitzer 1982.

, Produkthaftung Bd. I Strafrecht, $2^{\mathrm{a}}$ edición, Heidelberg: Recht und Wirtschaft, 1988. 
CONTRERAS, Lautaro. "La posición de garante del fabricante en el Derecho penal alemán”.

SCHMUCKER, Andrea, Die „Dogmatik“ einer strafrechtlichen Produktverantwortung, Frankfurt am Main: Peter Lang, 2001.

SCHUMANN, Heribert, Strafrechtliches Handlungsunrecht und das Prinzip der Selbstverantwortung der Anderen, Tübingen: Mohr Siebeck, 1986.

,"Responsabilidad individual en la gestión de empresas - Observaciones sobre la Sentencia Erdal del Tribunal Supremo Federal alemán (BGH)”, en: MIR, Santiago; LUZÓN, Diego (Editores), Responsabilidad penal de las empresas y sus órganos y responsabilidad por el producto, Barcelona: Bosch, 1996, pp. 199-213.

SCHÜNEMANN, Bernd, Unternehmenskriminalität und Strafrecht, Köln: Carl Heymanns, 1979.

"Strafrechtsdogmatische und kriminalpolitische Grundfragen der Unternehmenskriminalität", wistra 1982, pp. 41-50.

"Zum gegenwärtigen Stand der Dogmatik der Unterlassungsdelikte in Deutschland", en: GIMBERNAT, Enrique et al (Editores), Internationale Dogmatik der objektiven Zurechnung und der Unterlassungsdelikte, Heidelberg: Müller, 1995, pp. 49-82.

, "Unternehmenskriminalität”, en: ROXIN, Claus; WIDMAIER, Gunther (Editores), 50 Jahre Bundesgerichtshof Festgabe aus der Wissenschaft Band IV Strafrecht Strafprozessrecht, München: C. H. Beck, 2000, pp. 621-646.

, "Zur Garantenstellung beim unechten Unterlassungsdelikt", en: BÖSE, Martin; STERNBERG-LIEBEN, Detlev (Editores), Grundlagen des Straf- und Strafverfahrensrechts Festschrift für Knut Amelung zum 70. Geburtstag, Berlin: Duncker \& Humblot, 2009, pp. 303-323.

SCHWARTZ, Martina, Strafrechtliche Produkthaftung Grundlagen, Grenzen und Alternativen, Frankfurt am Main: Peter Lang, 1999.

SILVA, Jesús, El nuevo Código Penal Cinco cuestiones fundamentales, Barcelona: Bosch, 1997.

SPINDLER, Gerald, “\$ 823”, en: BAMBERGER, Heinz Georg ROTH, Herbert (Editores), Beck'scher Online-Kommentar BGB, 20ª Edición, München: C. H. Beck, 2011.

STREE, Walter, "Ingerenzprobleme", en: KOHLMANN, Günter (Editor), Festschrift für Ulrich Klug zum 70. Geburtstag, Tomo II, Berlin: Deubner, 1983, pp. 395-404.

, "Garantenstellung kraft Übernahme", en: GEERDS, Friedrich; NAUCKE, Wolfgang (Editores), Beiträge zur gesamten Strafrechtswissenschaft Festschrift für Hellmuth Mayer zum 70. Geburtstag am 1. Mai 1965, Berlin: Duncker § Humblot, 1966, pp. 145-164.

STREE, Walter; BOSCH, Nikolaus, "StGB § 13 Begehen durch Unterlassen", en: Schönke/Schröder Strafgesetzbuch Kommentar, 29ª edición, München: C. H. Beck, 2014.

VAN WEEZEL, Alex, “Autoría y responsabilidad por el producto: ¿participación en decisiones de órganos colegiados como intervención delictiva?", en: VAN WEEZEL, Alex, Pena y Sentido Estudios de Derecho Penal, Lima: Editorial Ara, 2008, pp. 371396.

VOGEL, Joachim, "Stand und Entwicklung der strafrechtlichen Produkthaftung", en: RAUSCHER, Thomas (Editor), Festschrift für Werner Lorenz zum 80 Geburtstag, München: Sellier, 2001, pp. 65-82 
Polít. crim. Vol. 12, № 23 (Julio 2017), Art. 1, pp. 1-55.

[http://www.politicacriminal.cl/Vol_12/n_23/Vol12N23A1.pdf]

WAGNER, Gerhard, "BGB $§ 823$ Schadenersatzpflicht”, en: SÄCKER, Franz Jürgen et al (Editores), Münchener Kommentar zum Bürgerlichen Gesetzbuch, Tomo 5, $6^{\mathrm{a}}$ edición, München: C. H. Beck, 2013.

WEI $\beta$, Holger, Die rechtliche Gewährleistung der Produktsicherheit, Baden-Baden: Nomos, 2008.

WEIßER, Bettina, Kausalitäts- und Täterschaftsprobleme bei der strafrechtlichen Würdigung pflichtwidriger Kollegialentscheidungen, Berlin: Duncker \& Humblot, 1996.

WELP, Jürgen, Vorangegangenes Tun als Grundlage einer Handlungsäquivalenz der Unterlassung, Berlin: Duncker \& Humblot, 1968.

WESSELS, Johannes et al, Strafrecht Allgemeiner Teil Die Straftat und ihr Aufbau, 44a edición, Heidelberg: Müller, 2014.

WOHLERS, Wolfgang; GAEDE, Karsten, "StGB § 13 Begehen durch Unterlassen”, en: KINDHÄUSER, Urs et al (Editores), Nomos Kommentar Strafgesetzbuch, Tomo 1, $4^{\text {a }}$ edición, Baden-Baden: Nomos, 2013.

ZIPPELIUS, Reinhold; WÜRTENBERGER, Thomas, Deutsches Staatsrecht Ein Studienbuch, 31 ${ }^{\mathrm{a}}$ edición, München: C. H. Beck, 2005. 